\title{
BRANDING THE CORPORATE WINERY
}

by FINN SANSOM 


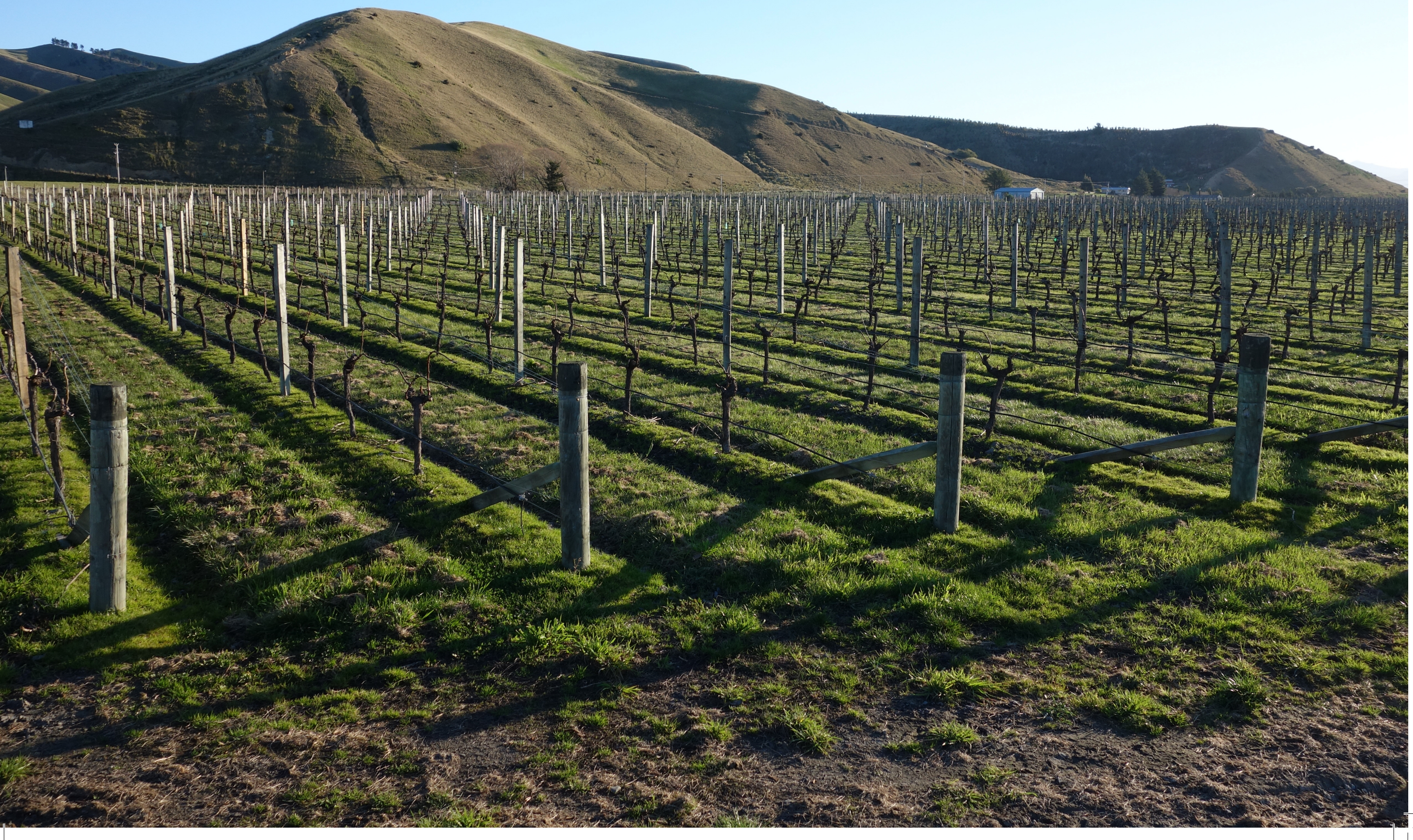




\title{
BRANDING THE CORPORATE WINERY
}

\author{
by FINN SANSOM
}

A thesis submitted in partial fulfilment of the requirements for the degree MASTER OF ARCHITECTURE (Professional)

VICTORIA UNIVERSITY OF WELLINGTON MARCH 2015 


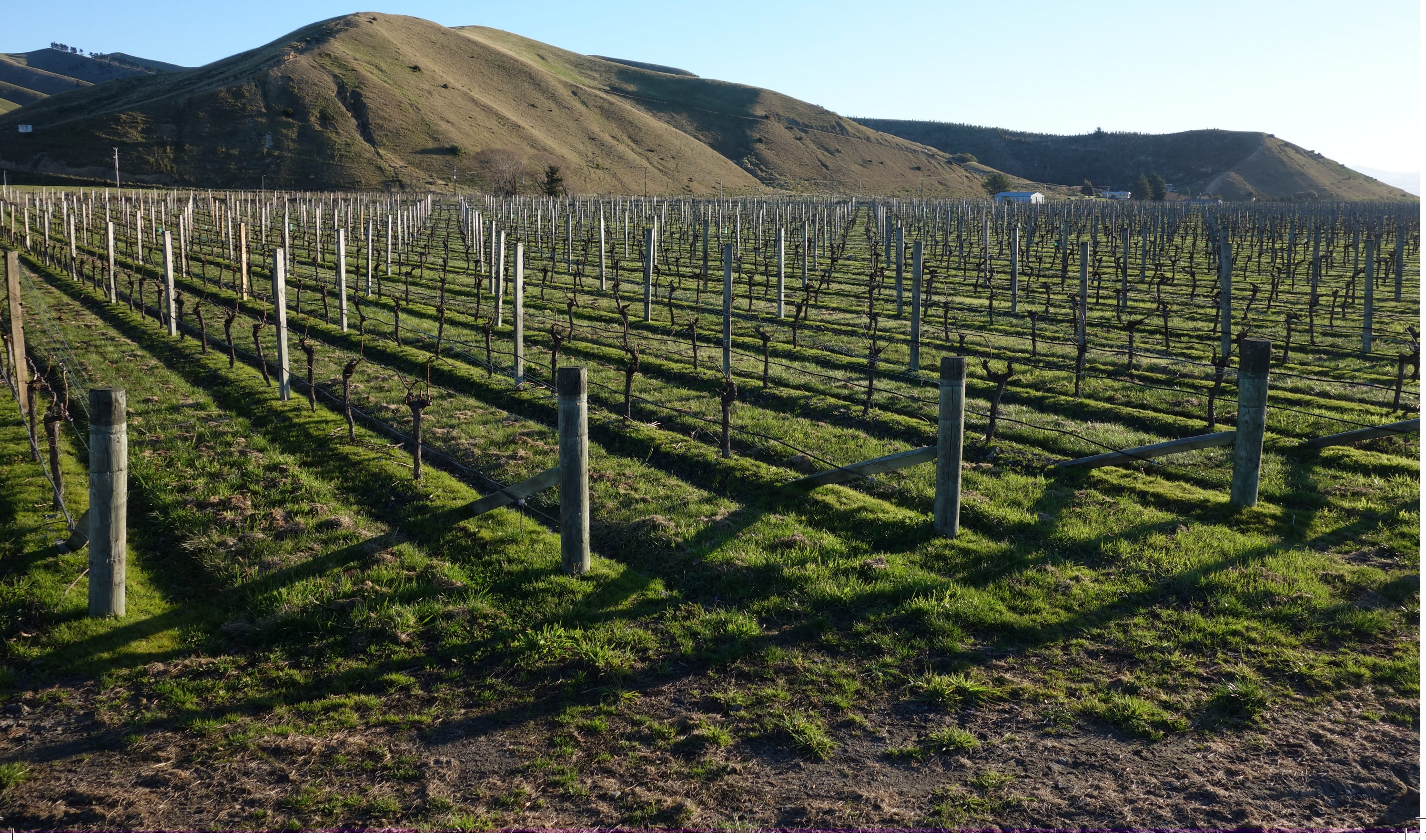




\section{Acknowledgements.}

I would like to acknowledge the following people who provided assistance and support for this project:

My Supervisor Tobias Danielmeier

My Family for their moral and financial support

My fellow Post and Under Graduates

All my close friends

Technical, Admin and Academic staff at the Faculty of Architecture and Design, VUW

THANK YOU. 


\footnotetext{
Abstrorct Corporate branding can be an important part of a company's communication strategy. The corporate identity shapes how a company is known and perceived by the public. Logo's, jingles, products and advertising are only part of the shaping of this image. It has been identified that architecture can play a significant role too (Melewar \& Jenkins, 2002).

The wine industry in New Zealand is very competitive and has a very involved relationship with the public. This thesis explores how a wine company can display corporate values through architecture.

Using Pernod Ricard as the company, and a new winery production facility as the case study, the thesis will use architectural design elements to produce a functional winery with a unique experience driven by Pernod Ricard's values. Being an international cooperation, place specific values as well as sub-brand values compete with core values of the company. These factors present an interesting architectural investigation.
} 


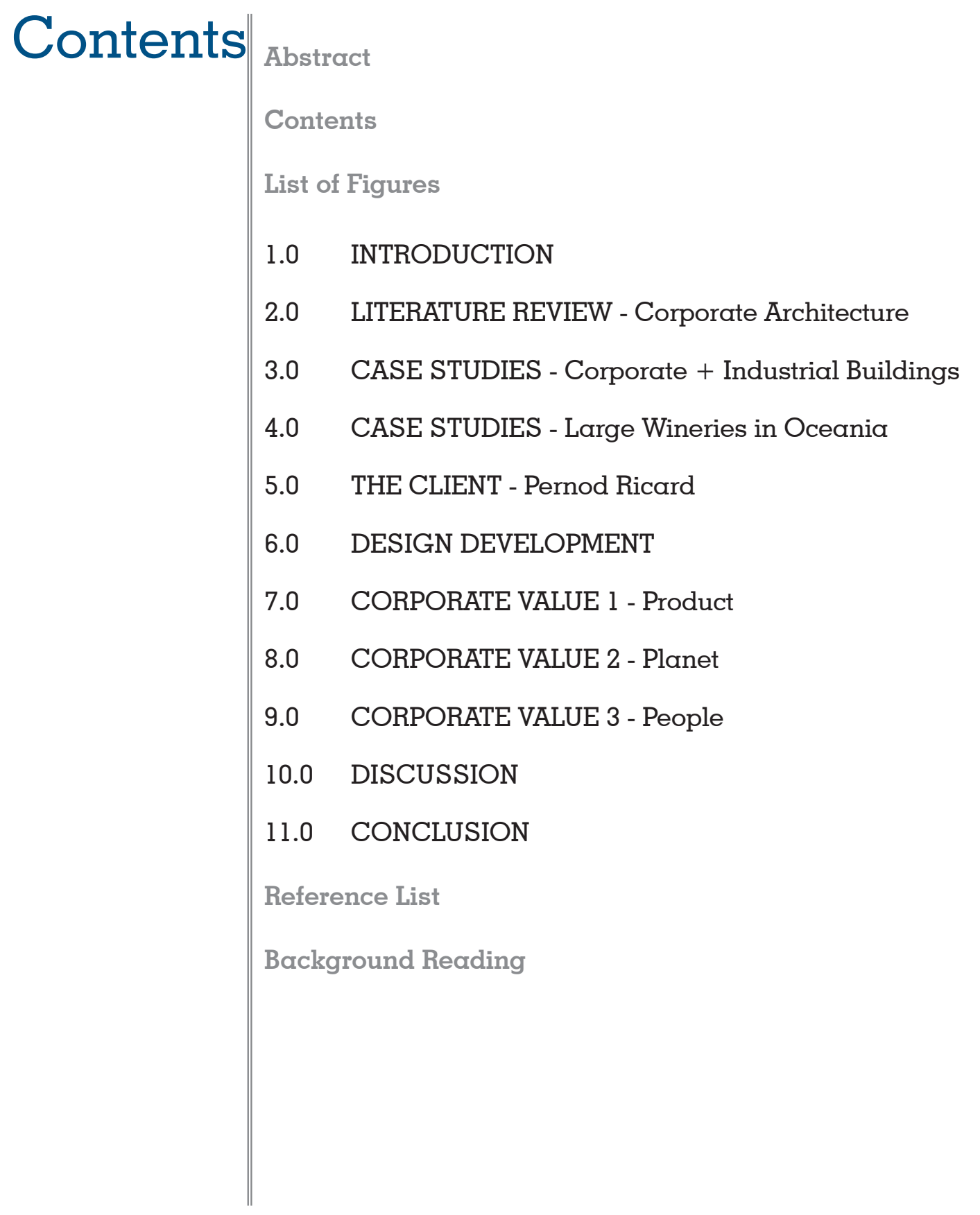




\section{List of Figures. $\begin{array}{ll}2.0 & \begin{array}{l}\text { Tite Page image by author } \\ 2.1\end{array} \\ \text { Corporate Architecture }\end{array}$ \\ Corporate Architecture Diagram diagram drawn from Messedat, \\ (2005) Corporate Architecture: Developments, Concepts, Strategies. Ludwigsburg: avedition GmbH. p. 24 \\ Pernod Pavilion picture credit to Messedat, $\rfloor$ \\ (2005) Corporate Architecture: Developments, Concepts, Strategies. Ludwigsburg: avedition GmbH. p. 56 \\ 2.3 Venturi's Duck and Decorated Shed picture credit to Venturi, Robert; Scott Brown, Denise; Izenour, Steven \\ (1997) Learning from Las Vegas, Cambridge, Massachusetts \\ Long Island Duckling photo credit to Clarke, $\mathrm{K}$ \\ (2010) http://4.bp.blogspot.com/_CrmyZ_pLfWY/TE3xwhwC9GI/AAAAAAAAACc/awHIsk9Kdho/s1600/summer+001.jpg \\ First "Golden Arches" Restaurant photo credit to Hong, B \\ (2007) http://commons.wikimedia.org/wiki/File:DowneyMcdonalds.jpg \\ I am a Monument picture courtesy of Venturi, Robert; Scott Brown, Denise; Izenour, Steven \\ (1997) Learning from Las Vegas, Cambridge, Massachusetts \\ Klingmann's Inverted Shed artwork by Klingmann, A \\ (2007) Brandscapes Architecture in the Experience Economy, Cambridge, Massachsetts: MIT Press 2007, p. 191 \\ Ricola AG Production and Warehouse Buildings photo credit to Messedat, $\rfloor$. \\ (2005) Corporate Architecture: Developments, Concepts, Strategies. Ludwigsburg: avedition GmbH. p. 131 \\ Ricola AG Production and Warehouse Buildings photo credit to Messedat, J. \\ (2005) Corporate Architecture: Developments, Concepts, Strategies. Ludwigsburg: avedition GmbH. p. 133 \\ 3.0 Title Page image by Author \\ Building Concept Type Diagram \\ diagram drawn by Author}


AEG Logo Image credit to Benoît Dedieu-Anglade

http://www.pinterest.com/pin/396457573416724399/?z=1

AEG Electric Kettle Image credit to T, Lee

http://o.quizlet.com/u1kVz82GtreA4bm1p8vVpg_m.jpg

AEG Turbine Factory Frontage Image credit to Wolfsraum

http://www.flickriver.com/photos/wolf-rabe/sets/72157626061754277/

AEG Turbine Factory Interior Image credit to Architales

https://architales.wordpress.com/2014/08/05/peter-behrens-the-first-industrial-designer-in-history/

AEG Electric Fan Image credit to Chris Pritchard Clayton

http://www.prices4antiques.com/item_images/medium/52/80/20-01.jpg

AEG Turbine Factory Facade Image credit to Jose Garcia

http://www.mimoa.eu/projects/Germany/Berlin/AEG\%20Turbinenfabrik

AEG Turbine Factory Facade Image credit to Jose Garcia

http://www.mimoa.eu/projects/Germany/Berlin/AEG\%20Turbinenfabrik

Olivetti Factory at Pozzuoli Plan Drawing credit to Cosenza, G.

(2006). The Olivetti Factory in Pozzuoli. Napoli: CLEAN. p. 61

3.10 Olivetti Factory at Pozzuoli Image credit to Cosenza, G.

(2006). The Olivetti Factory in Pozzuoli. Napoli: CLEAN. p. 93

Olivetti Factory at Pozzuoli Image credit to Cosenza, G.

(2006). The Olivetti Factory in Pozzuoli. Napoli: CLEAN. p. 145

Olivetti Factory at Pozzuoli Image credit to Cosenza, G.

(2006). The Olivetti Factory in Pozzuoli. Napoli: CLEAN. p. 187

3.13 Luigi Consenza's Drawings Drawing credit to Cosenza, $G$

(2006). The Olivetti Factory in Pozzuoli. Napoli: CLEAN. p. 39-53

3.14 Cloverleaf Plan Drawing credit to Schwanzer, Karl

(1973) Architektur aus Liedenschaft. 25 Jahre Arbeit.Wien, Munchen: Modulverla GmbH 1973. p. 114

(1973) Architektur aus Liedenschaft. 25 Jahre Arbeit.Wien, Munch

(1973) Architektur aus Liedenschaft. 25 Jahre Arbeit.Wien, Munchen: Modulverla GmbH 1973. p .115 Detailed Facade System Image credit to Schwanzer, Karl

(1973) Architektur aus Liedenschaft. 25 Jahre Arbeit.Wien, Munchen: Modulverla GmbH 1973. p .116

Mercedes Logo Image credit to Mercedes Benz Corporate Website

http://www.mercedes-benz.com/en/

Mercedes Benz Museum Plan Picture credit to UNStudio

(2007) UNStudio After Images, Amsterdam p. 32

Mercedes Benz Museum Plan Picture credit to UNStudio

(2007) UNStudio After Images, Amsterdam p. 33

Mercedes Benz Museum Plan Diagram credit to UNStudio

(2007) UNStudio After Images, Amsterdam p. 39

Mercedes Benz Museum Plan Image credit to UNStudio

(2007) UNStudio After Images, Amsterdam p. 31

Mercedes Benz Museum Plan Image credit to UNStudio

(2007) UNStudio After Images, Amsterdam p. 74

Mercedes Benz Museum Plan Image credit toUNStudio

(2007) UNStudio After Images, Amsterdam p. 43

BMW Welt Image Image credit to BMW Group

http://www.bmw-welt.com/en/events/silvester_2013.html

BMW Welt Cyclone Image credit to Morfae

http://www.morfae.com/xa333-coop-himmelblau/

3.26 BMW Welt Interior Cyclone Image credit Coop Himmelb(I)au 
http://www.e-architect.co.uk/architects/coop-himmelblau

BMW Welt Interior Cyclone Image credit Tom Williams, BMW

http://www.tomwilliamsbmw.com/europeon-delivery-program.htm

BMW Welt Interior Cyclone Image credit Neccesary Indulgences

2012) http://necessaryindulgences.com/2012/11/bmw-welt-european-delivery/

Welt Interior Cyclone Image credit Neccesary Indulgences

(2012) http://necessaryindulgences.com/2012/11/bmw-welt-european-delivery/

BMW Welt Interior Cyclone Image credit Matt van Vuuren

http://www.reformatt.com/blog/bmw-welt

3.31 Autostadt Masterplan Image credit Hot Water Drive

http://www.hotwaterdrive.com/plan/discover/autostadt1/autostadt.gif

Autostadt Masterplan Image credit Henn, G

http//www.henn.com/de/projects/urban-design/autostadt

Autostadt Car Garage Towers Image credit AUSmotive

(2009) http://www.ausmotive.com/2009/04/16/autostadt-counts-18-millionth-visitor.html

Autostadt Car Garage Towers Image credit Piximus

(2012) http://piximus.net/vehicles/autostadt-car-garage-towers-in-germany

Autostadt Pavillions Images Credit to Autostadt

http://www.autostadt.de/en/explore-the-autostadt/pavilions/

Autostadt Pavillions Images Credit to Autostadt

http://www.autostadt.de/en/explore-the-autostadt/pavilions/

Kozenforum Image Credit to Merian.de

http://blog.hslu.ch/outofhomedisplays/2010/03/17/volkswagen-autostadt-wolfsburg/

Kozenforum Image Credit to Henn, $G$

http://blog.hslu.ch/outofhomedisplays/2010/03/17/volkswagen-autostadt-wolfsburg/

Title Page image by Autho

Magill Estates Winery Image Credit Grant, S

2014 December) Penfolds Grange commands awe, The Australian.

Magill Estates Restaurant Image Credit to Double Dutch Oven

2011, June 3), https://doubledutchoven.wordpress.com/tag/henschke/

Barossa Valley Winery Image Credit to Bongers, R

(2010, December 10) Penfold's Winery-Nuriootpa, http://www.panoramio.com/photo/45306378

Barossa Valley Winemaking Image Credit to Bouskill, D. \& Corbell, D

(2013, July 24). A Barossa Valley Blend, http://theplanetd.com/two-grumpy-spaniards-and-a-barossa-valley-blend/

Casella Winery Image Credit to Cultivate Construction

(2006), http://cultivateconstruction.com.au/56/casella-wines/

Casella Winery Image Credit Truong Anh Wines and Spirits Distribution

(2008). YELLOWTAIL - 10 ĐIỀU NÊN BIẾT, http://www.yellowtailwine.com/media/102357/Tanks_3.jpg

Title Page image by Author

Pernod Ricard Company Structure Diagram

Pernod Ricard Corporate Values

Location of Pernod Ricard Winery (formerly Montana)

Regional Map + Pernod Ricard Winery

Surrounding Area of Pernod Ricard Winery

Site Axonometric of Pernod Ricard Winery 


\section{Boundary 1}

Boundary 2

Boundary Diagram

Boundary 3

Boundary Diagram

Boundary 4

Vista Diagram

Vista 1

Vista 2

Peregrine Approach Analysis

Craggy Range Approach Analysis

Mission Estate Approach Analysis

Woollaston Estate Approach Analysis

Pernod Ricard Approach Analysis

Pernod Ricard Carparking layout Analysis

Pernod Ricard Growth Analysis

Pernod Ricard Sun Orientation Analysis

Above Images by Author

Title Page image by Author

Development Timeline

Development Timeline

Experience Strategy Diagram

Grid Study Diagram

Grid Study Diagram

Massing Study Diagram

Massing Study Diagram

Pernod Ricard Site Plan

Above Images by Author

Title Page image by Author

Winemaking Process Diagram

Perpendicular Experience Diagram

Parralel Experience Diagram

External Product Experience Diagram

Section of Fruit Handling, Open Fermentation and Fermentation

Internal Product Experience Diagram

Section of Product Tasting Room

Product Experience Plan

Product Experience Section

External Product Experience

Internal Product Experience

Above Images by Author 
Massing and Layout Diagram after Change

Part Section showing Green Systems

External Planet Experience Diagram

Section of Planet External Facade Systems

Internal Planet Experience Diagram

Tower Tasting Room Section

Planet Experience Plans

Planet Experience Sections

External Planet Experience

Internal Planet Experience

Above Images by Author

Title Page image by Author

External People Experience Diagram

Cross Section of Programme Relationship

Internal People Experience Diagram

Long Section of Programme Relationship

People Experience Plans

People Experience Section

External People Experience

Internal People Experience

Above Images by Author 


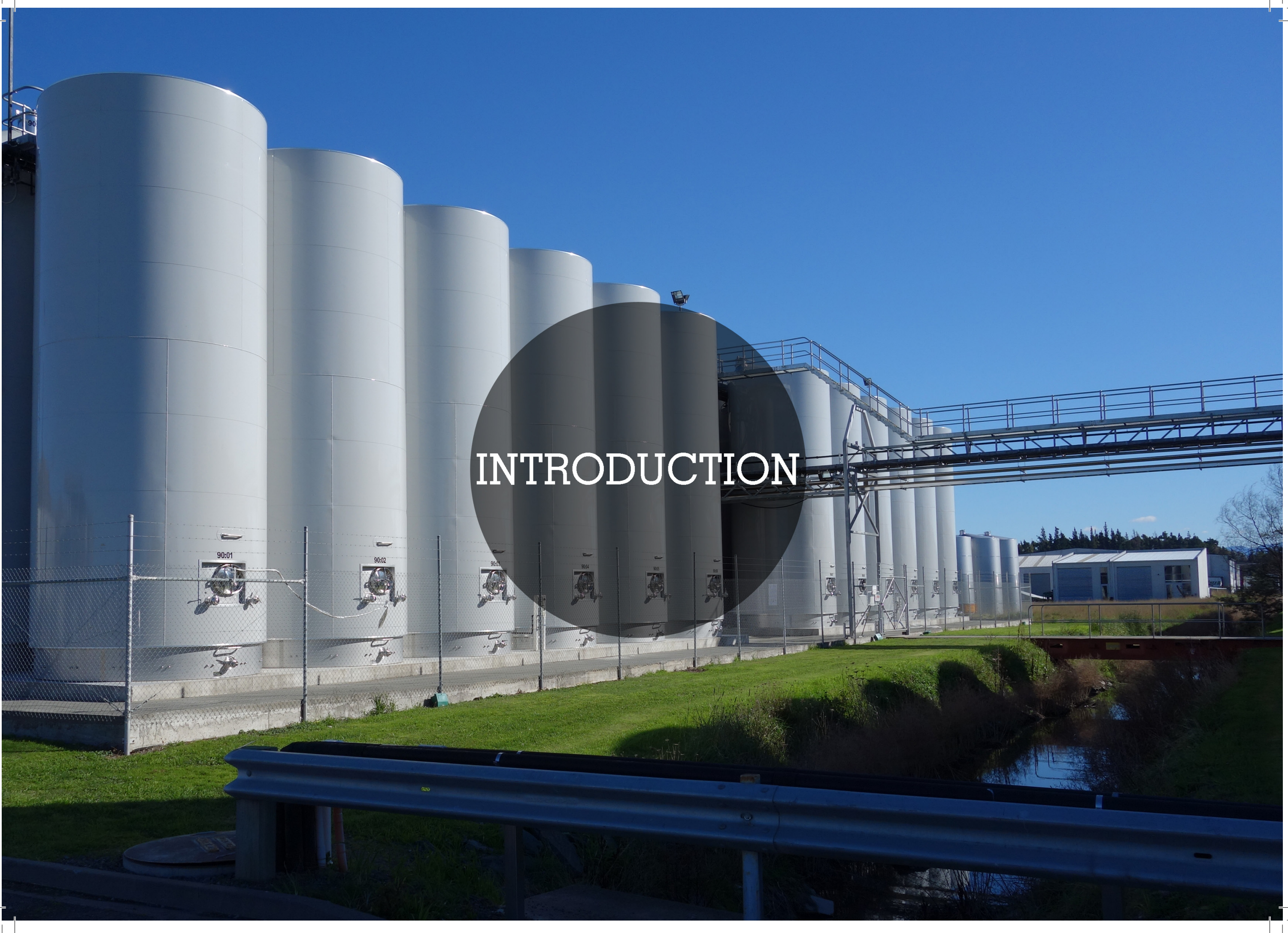




\section{$1.0 \mid$ INTRODUCTION}

Briefly outlines the thesis question of the project, the setting of the design proposal and the reason for undertaking the research. The introduction also summarises what is covered in each chapter. 
Corporate architecture has become a significant part of construction throughout the world due to the positive affect it can have on a company's image. Within New Zealand we have a competitive wine industry and in recent times there has been an interest shown by wineries to use corporate architecture to advertise their company. Of interest is Pernod Ricard New Zealand, owner of one of New Zealand's most exported wines Brancott Estate and owned by Pernod Ricard, the second largest wines and spirits distributor in the world. Currently they produce wine out of a facility in Marlborough however this does not communicate Pernod Ricards corporate identity because this building was originally built for Montana. This suggests the need for a corporate winery design.

Yet in recent times corporate architecture has been travelling towards an experience based design which may not be applicable to a winery context because of the functionalist aspect it requires. In order to understand the different approaches of corporate architecture the thesis analyses corporate architectural concepts and investigates corporate buildings. The design research considers how Behrens was able to draw connections between building functionality and AEG's corporate identity. Venturi, Scott Brown and Izenour's renowned work on Las Vegas's strip is considered to find direct contrasts between signs and forms. Finally, Klingmann's 'inverted shed' concept is a used as a platform to explore the interface of function and experiences.

Based on the literature review the thesis investigates how a winery architecture, can incorporate specific company values of Pernod Ricard. The underlying research question ponders how can experience be incorporated into a process driven design to show the corporate identity of a company? 
Briefly outlines the thesis question of the project, the setting of the design proposal and the reason for undertaking the research. The introduction also summarises what is covered in each chapter.

\subsection{LITERATURE REVIEW - Corporate Architecture}

This section discusses the importance of architectural branding for business and cooperations. The section goes on to review ways that corporate 1 has been communicated in the past and defines what it is.

\subsection{CASE STUDIES - Corporate + Industrial Buildings}

This chapter investigates how architects have shown a companies corporate identity through a building. The case studies investigates functionalist corporate buildings, the experience provided by corporate buildings and what design elements are used to influence these.

\subsection{CASE STUDIES - Large Wineries in Oceania}

This chapter analyses wineries of similar scale to Pernod Ricard and how they have decided to market themselves through their production facilities.

\subsection{THE CLIENT - Pernod Ricard}

The chapter introduces the client, their corporate identity and their company structure. It also investigates the site which they currently own in Marlborough. 


\subsection{DESIGN DEVELOPMENT}

The section timelines the design process undertaken, early planning and massing studies and diagrams the masterplan of the design.

\subsection{CORPORATE VALUE 1 - PRODUCT}

The section showcases key features of the product experience using images and diagrams to explain how the product corporate value is communicated.

\subsection{CORPORATE VALUE 2 - PLANET}

The section showcases key features of the planet experience using images and diagrams to explain how the planet corporate value is communicated.

\subsection{CORPORATE VALUE 3 - PEOPLE}

The section showcases key features of the people experience using images and diagrams to explain how the people corporate value is communicated.

\subsection{DISCUSSION}

Discusses the design proposal referencing documented corporate architectures and the functional and experiential qualities of the building.

11.0 CONCLUSION

Reflects upon hybrid corporate architecture as a design driver for wineries. 


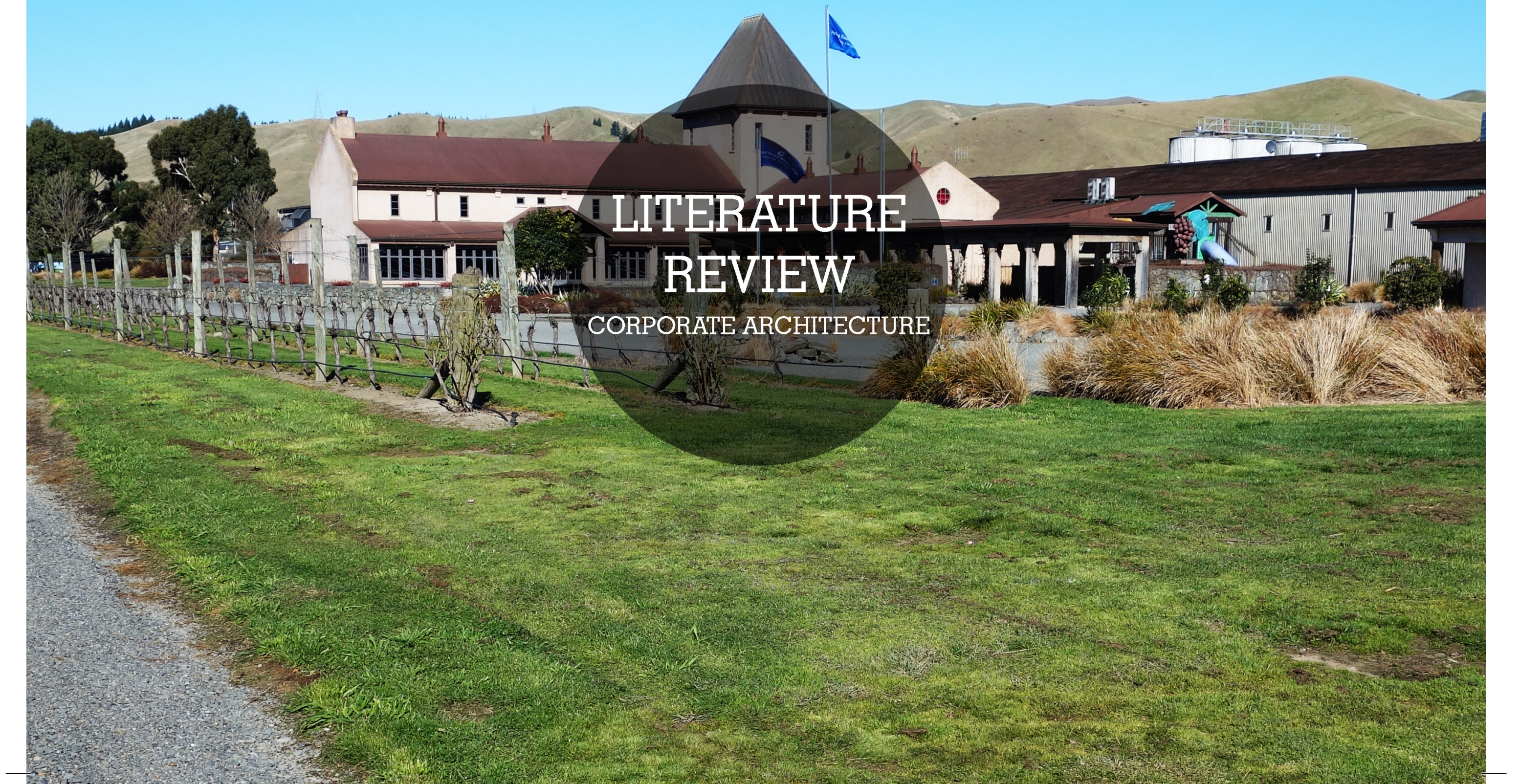




\subsection{LITERATURE REVIEW - Corporate Architecture}

This section discusses the importance of architectural branding for businesses and cooperations. The section goes on to review ways that corporate architecture has been communicated in the past and defines what it is. 
All over the world corporate buildings play a massive part in the shaping of the built environment, working on varying scales from rural to city locations. Because of the affect these buildings can have on the built environment there is space for research into what drives the designs of these buildings and whether this produces not just marketable benefits but successful architecture.

What is of importance in a consumer based society is the corporate buildings ability to visually communicate the disposition of a particular company, suggests Raffelt, Schmitt, \& Meyer (2013). Already verified through prior research from marketing scholars is proof that even small scale visual design elements such as packaging (DeBono, Leavitt, \& Backus, 2003), products (Brunel, 2006), logos (Henderson \& Cote, 1998) and typographies (Henderson, Giese, \& Cote, 2004) have the ability to show company beliefs. Corporate Architecture however is a larger more intricate facet of visual expression and overall there is a consensus that has been around for a period of time that suggests the architecture as much as the logos and symbolism can be used to form an identity of how the corporation is 'known' and that Architecture and the location is often forgotten and under-represented in research findings (Melewar \& Jenkins, 2002). More recently it appears that the "research has largely neglected the issue relation between corporate architecture and brand personality" (Raffelt, Schmitt, \& Meyer, 2013, p. 201) and this would suggest a research need. 
One might feel that it would be harder to explain a company without words and that a written bill board would be more effective due to the generally perceived belief that a verbal explanation is easier to understand than a symbolic form. However the Dual Code Theory (DCT) developed by Allan Paivio suggests that visual and verbal information act in different parts of the brain. The benefits of using visual imagery to create mental images is that they can be perceived quicker, understood more easily, stored in the memory for longer and therefore learned. If the images arouse emotion from the viewer the images are stored even more effectively (Paivio, 1986). The fact that the more emotive an image the more likely it is to be stored in a person's brain is a promising factor for using the visual images formed by architecture to create experience and ultimately store the values of the company in customers. "Corporate architecture has the potential to lead to the creation of clear, unique mental images in the minds of the internal and external target groups" (Herbst \& Maisch, 2009, p. 2). The key principle is that recall or recognition of a corporate identity is far more enhanced if the information is presented not only verbally but also importantly visually. With this in mind there is no reason why one could not produce corporate architecture that is not only respected in a marketing sense but also in architectural theory.

In the last two decades the wine industry in New Zealand has become increasingly competitive (New Zealand Winegrowers, 2013). Statistics taken from the New Zealand Wine Growers annual report show that in 1990 there were 131 wineries across New Zealand (Brodie, Benson-Rea, \& Lewis, 2008) compared with 2013 where there were a total of 698 wineries recording an increase of approximately $550 \%$ in the last 20 years (New Zealand Winegrowers, 2013). With so many wineries now in New 
Zealand the way in which wineries market themselves nationally has become extremely important.

Winepartners writes that where many wineries make mistakes is by ignoring the marketing of their brand relying on the quality of their vintage to sell who they are (2009). "The wine sector is populated by a large number of underachievers, not in viticulture and winemaking, but in branding marketing and sales" (Winepartners, 2009). Because of the strong connection between the wine sector and marketing along with the competitive environment that New Zealand has, a winery for an under represented company with an established corporate identity would provide an ideal building to research the value of corporate architecture.

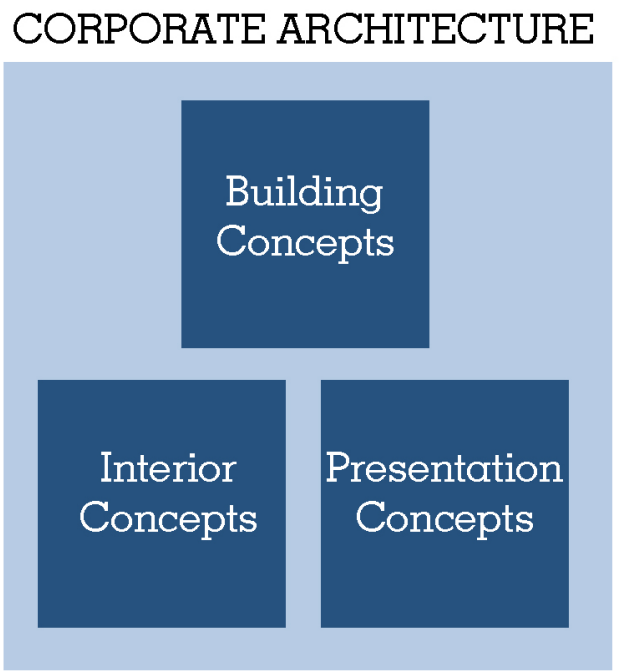

fig 2.1 Corporate Architecture Diagram diagram drawn from Messedat 2005 p. 24

\subsection{HOW HAS CORPORATE ARCHITECTURE BEEN EXPRESSED?}

There are three main types of corporate architecture; the building concept, interior concept and presentation concepts [fig 2.1]. Interior concepts exist mainly as specific store designs housed in various larger buildings while presentation concepts consist of mobile stands or exhibitions. A winery falls into the building concept because the programme/function of the building is fixed in a location and generally has a singular venture (Messedat, 2005). So how can corporate architecture be expressed through a building concept? 
A common way throughout history to express a particular person, settlement or group of people through a building was by means of Symbolic Architecture. "Signs and symbolic buildings that suggest an association to their use can be found throughout the entire history of building" (Messedat, 2005, p. 50). The use of symbolism to express a company's product, values, educational ideas, religion or history of an organisation is a historic design driver used in architecture as a promotional tool to this day.

Many examples of symbolic architecture were shown at the Exhibition of the Works of Industry of all Nations which occurred annually across the globe. This was because it provided an ideal opportunity for businesses to present themselves through the use of pavilions at locations far from the companies head office and ultimately leave a lasting impression on customers not familiar with the company (Messedat, 2005, p. 55). An example where symbolism has used within the pavilion to advertise the product was designed by the Pernod Company (merged with Ricard to become Pernod Ricard) in 1937. The pavilion had set atop a large anisette aperitif coloured glass sculpture that could be seen from afar [fig 2.2]. The shining yellow colour of the glass was symbolic of the bottle that contained the 'Pastis' that Pernod was producing at that point in time (Messedat, 2005).

The realisation of symbolism as a design driver lead to two historic concepts of architecture that directly advertised the company and in particular the product visually. The concept was known as 'Duck Architecture' and 'Decorated Sheds' (Messedat, 2005) [fig 2.3]. The difference between a 'Duck' and a 'Decorated Shed' was originally defined by Venturi, Scott-Brown and Izenour. "The duck is the

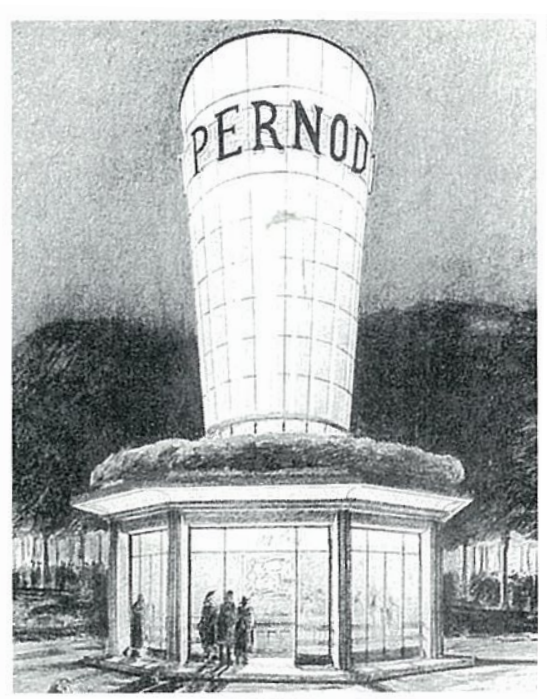

fig 2.2 picture credit to Messedat 2005 p. 56
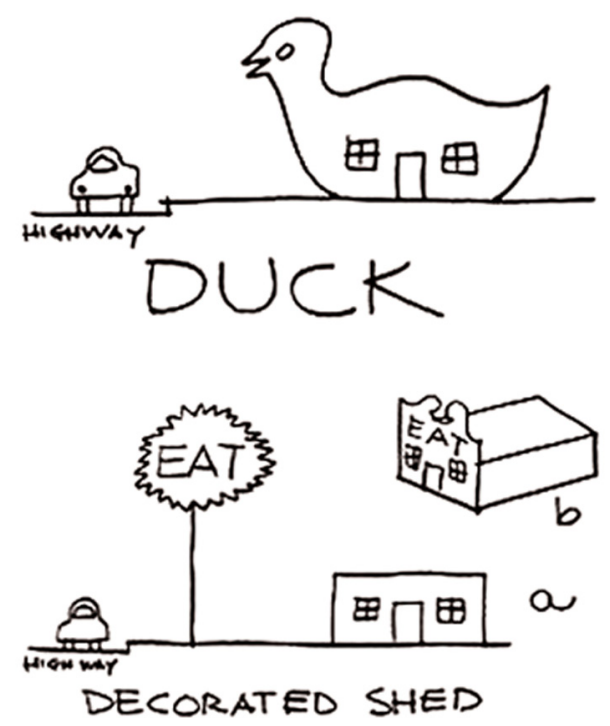

fig 2.3 Venturi's Duck and Decorated Shed

picture credit to Venturi, Robert; Scott Brown, Denise; Izenour, Steven 


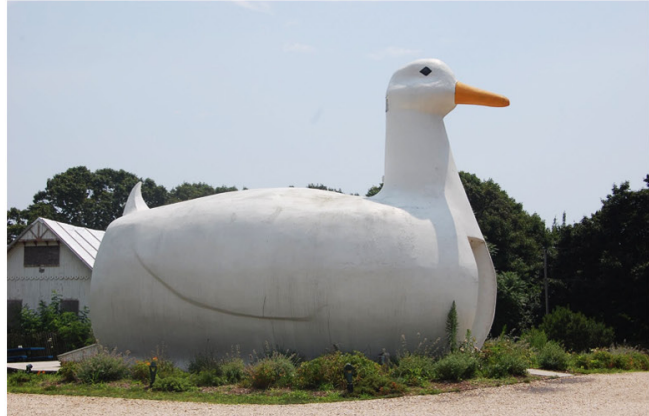

fig 2.4 Long Island Duckling photo credit to Clarke, Kelly 2010

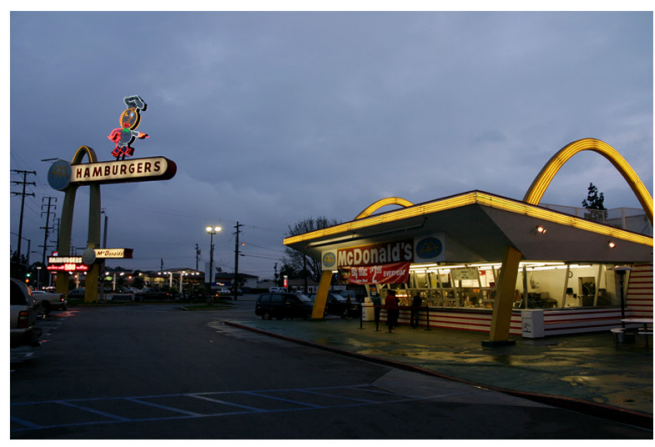

fig 2.5 First "Golden Arches" Restaurant photo credit to Hong, Bryan 2007 special building that is a symbol; the decorated shed is the conventional shelter that applies symbols" (Venturi, Brown, \& Izenout, 1997, p. 87). A review on the book Learning from Las Vegas published in Inland Architect understood the process of designing the decorated shed as "Firstly, the building shell is designed to a program, and then ornament is applied"' (Thalden, 1993, p. 22) in contrast to the 'Duck' "where the space, structure, and program are submerged and distorted by an overall symbolic form" (Thalden 1993, p. 23). A key difference between the two is to do with the functionality of the decorated shed. While the symbolic form takes priority in duck architecture over any other architectural element "the purpose of the decorated shed is to take an ordinary functionally designed building and make it appear more important than its parti might imply" (Schumacher, 2010, p. 137).

For example The Long Island Duckling's form was used to advertise as well as house the fried duck that was prepared and sold there (Venturi, Brown, \& Izenout, 1997) [fig 2.4]. Therefore the form of the body of the duck shell influenced the layout of the interior of the building. A decorated shed example was the first McDonald's 'Golden Arches' restaurant built in 1955 [fig 2.5]. In plan the building appears to be like any other restaurant, a general fast food layout is applied and windows and doors are placed to suit customers. From here the designers have introduced two golden arches that rise above the roof line of the building and the addition of a large sign separate from the building that makes reference to the golden arches. These arches and signage do not inhibit the program at all however send a strong imagery to the people driving past or visiting. This essentially trademarked the golden arches as a McDonalds brand icon leading to global expansion (Messedat, 2005). The key thing that 
classifies buildings into 'ducks' or 'decorated sheds' is their ability to communicate the company and ultimately instil the key element of recognition within its customers (Messedat, 2005). This type of recognition however is often only able to be generated within branch or franchise companies such as fast food restaurants, gas stations, hardware stores and supermarkets. The question remains can this be translated into a situation where the building is likely to be a one off.

These architectural concepts have proved extremely effective in terms of marketing however it is more difficult to produce recognition when a company is not at the scale where it needs or requires multiple buildings across a country or even within a city. Another criticism of this technique could be that it does advertise the company's product or use but does not emote the values that the company intends to be known for. Architecturally "with good reason, most architects deplored the Commercial Strip" (Jordy 2005 ) in Vegas due to the way it affected the streetscape's aesthetic.

There is debate amongst scholars to which design concept was more architecturally viable. The 'Duck' was undoubtedly effective however often sacrificed functionality for the eccentric forms that the buildings possessed. Historian and Architectural Critic William Jordy described the 'Decorated Shed' as "the most ubiquitous phenomenon in building - the anonymous box, a prototypical form to house the most various demands for shelter" (Jordy, 2005, p. 265). Although it appears as a criticism Jordy goes on to explain how efficient the box is in terms of cost, erection, light and air condition management. 


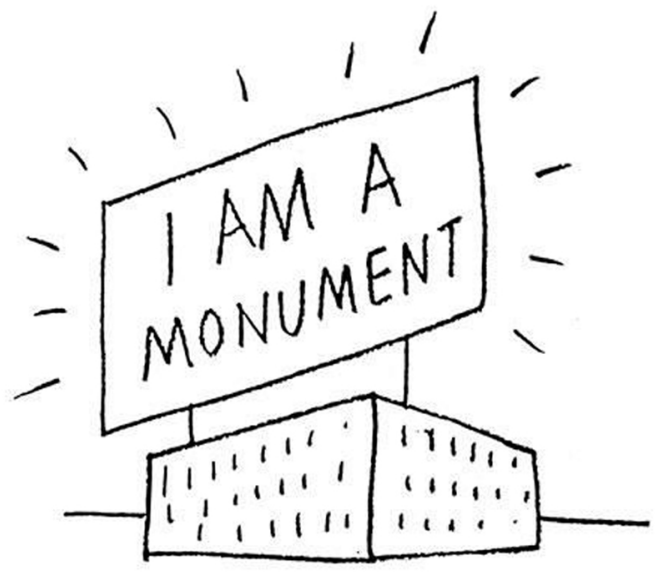

fig 2.6 I am a Monument picture courtesy of Venturi, Scott Brown and Associates, Inc
"But the box has special relevance to the current scene, for several reasons. In a time of high building costs and low building schools, the box is as cheaply and simply erected as any basic form of shelter. Technological developments in lighting and air conditioning make livable even in a box of substantial size, which needs a door for entrance but no windows. [...] [I]n the modern movement, moreover, the stripped-down box came to be accepted as an ultimate statement of both pure shape and pure function, a cachet of the style" (p. 265).

Venturi also appeared to prefer the decorated shed and the functional element that came with it at one point expressing his view on architects and their overuse of 'Ducks'. "Writing in the wake of the 'hero-architect' syndrome before setting off for Vegas, the Venturi team complained too many architects were creating ducks to their own glory" (Jordy, 2005, p. 266). Venturi's viewpoint appeared to be that the flamboyant use of 'duck architecture' should be left for unique occasions and most architects should learn to architecturalise the humble 'decorated shed' (Jordy, 2005).

Venturi's preference for the 'decorated shed' (or Jordy's description 'the anonymous box') puts a huge focus on the exterior skin of the building because of the anonymity of the form. "Like the false front in the traditional Western frontier town, one architectural box is differentiated from another - out of its transformed inner self - by scenery, decoration or sign" (Jordy, 2005, p. 265) [fig 2.6]. If the packaging of the box has a huge influence on communicating the corporate identity of the particular company why then should one remain restricted to a sign and a box? Surely the use of large bill boards to package the function or as a separate frontage to the shed as used in Las Vegas fails to create a uniqueness 
that promotes a specialised company if anything it suggests the average fast food restaurant or gas station. Klingmann in the book Brandscapes: Architecture in the Experience Economy aims to make the change from two-dimensional decoration into a three-dimensional public space which plays with the interface between private and public and inside and outside (Klingmann, 2007). This synergistic negotiation of the interface is referred to by Klingmann as the 'inverted shed' and appears to apply a far more contemporary and successful formulae to corporate architecture [fig 2.7].

A successful rendition of this ideology would result in the facade becoming an event space, programme integrated, exhibition or a visual spectacle (Tans, 2011). Rather than the two dimensionality of a billboard with its succinct, exterior, verbal messaging the facade becomes a three-dimensional, twoway, visual communicator of information to people passing by on foot, in vehicles or even to those experiencing the insides of the building.

The main issue is how one effectively shows the companies corporate identity through the facade and in a way that creates a striking visual image that is memorable. A key part is understanding the particular brand and discovering what the spirit of the company is. Facades have been proven for years to have the ability to communicate various ideas messages. "[T] he facade is a communicative event that tells stories through its changing materiality, representing the building and its contents, but also the particular ideologies and power dynamics of the city in relation to its inhabitants and broader economic political processes" (Gendelman \& Aiello, 2010, p. 256). The strength of the facade as a

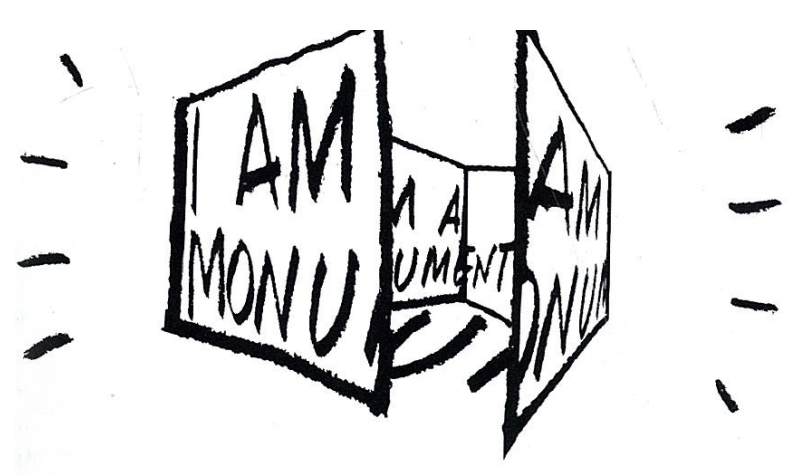

fig 2.7 Klingmann's Inverted Shed artwork by Klingmann, Anna: Brandscapes 


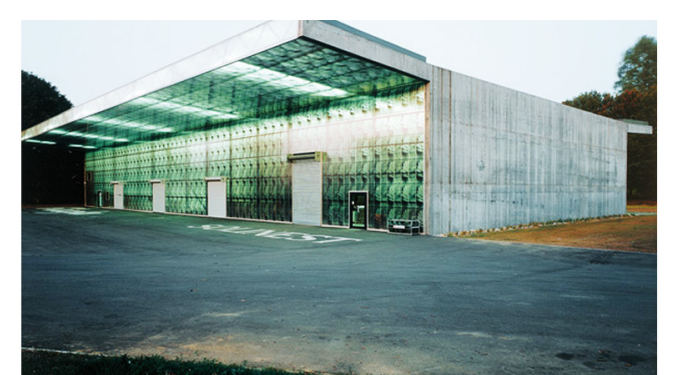

fig 2.8 Ricola AG Production and Warehouse Buildings picture courtesy Messedat 2005

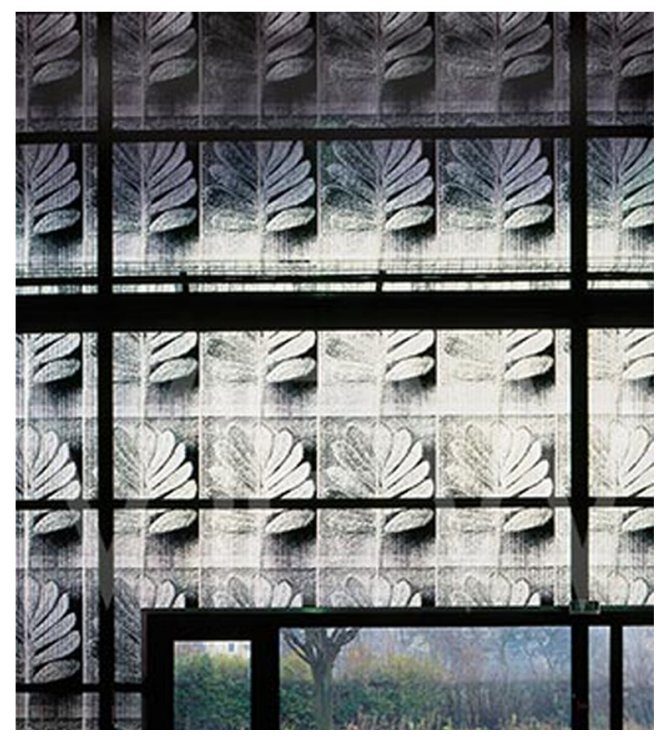

fig 2.9 Ricola AG Production and

Warehouse Buildings

picture courtesy Messedat 2005 communicator of not only a company or organisation in the present or as a historical landmark cannot be underestimated.

A contemporary example of facade manipulation can be found in the work of the Swiss based architecture firm Herzog and de Meuron. "The exploration of material and surface is one of the principal themes in their works" (Schittich, 2001, p. 19). Herzog and de Meuron often use images transposed onto the glass facade of a building to explain something about the functions or organisations existing in it $[2.9,2.10]$. Their work is often intended to tell a story and transform the facade into a projection screen (Ursprung, 2005). Their exploration of facades are not restricted to glass. The visually appealing detailing and symbolic connections of their varying and unique facade systems leaves a lasting impression on visitors

\subsection{DEFINITION OF CORPORATE ARCHITECTURE}

The car industry over the last half decade has taken a particular interest to corporate architecture. BMW has set the standards since the 1970's for architectural branding (Raffelt, Littich, \& Meyer, 2011). However in recent times Audi and Mercedez followed BMW's approach by constructing building concept designs in 2000 and 2006 respectively possibly causing BMW to respond with the Welt in 2007 (Raffelt, Littich, \& Meyer, 2011). This explosion of corporate architecture suggests there is financial 
value in building concept architecture particularly with the aim of generating customer awareness and commitment. Purist architects will contest the use of corporate identity as a design driver for corporate buildings seeing this as the end of architecture as an art form, finally selling out to the economic powers that rule the western world. However Klingmann believes people themselves are mostly responsible for this shift due to developments within the human race.

"People now search for content, aesthetics, originality, economic and personal growth, identity, or spirituality - all of which denote a fundamental shift from rational to an emotional system of values. [...] Architecture must transcend the dichotomy of form ('what it has') and program ('what it does') to aspire the levels of experience ('what you'll feel') and identification ('who you are and what you want to be')" (Klingmann, 2007, p. 322).

It has been identified that in this day and age it is easy for people to access information as well as the abundance of design that is produced around the world. This has resulted in the experience becoming far more important than the historical/conceptual/rational/functional content of which a building is based upon. "The more information-rich our society becomes, the more people value feelings over information" (Neumeier, 2003, p. 19). In these economically focussed times it is important for the architecture to perform its functional task using architectural elements but above all to send a specific emotive experience to the customer of who you are.

Corporate architecture's purpose is to promote the companies corporate identity however this is only 
analysing the concept at face value. Corporate architecture must also involve base architectural elements such as planning, scale, context, etc to strengthen the advertisement. Corporate architecture's quality lies in its negotiation between promoting the company with efficient production and implementation of service possibly by even incorporating Sullivan's form must follow function credo. Corporate architecture can blur the lines of production or service space with public experience and the use of facades as the bridge between the programmes. And finally, Corporate Architecture must use these facades as an aesthetic that communicates the corporate identity. The concatenation of these elements ultimately becomes the experience that embeds itself into the customer's memory. 


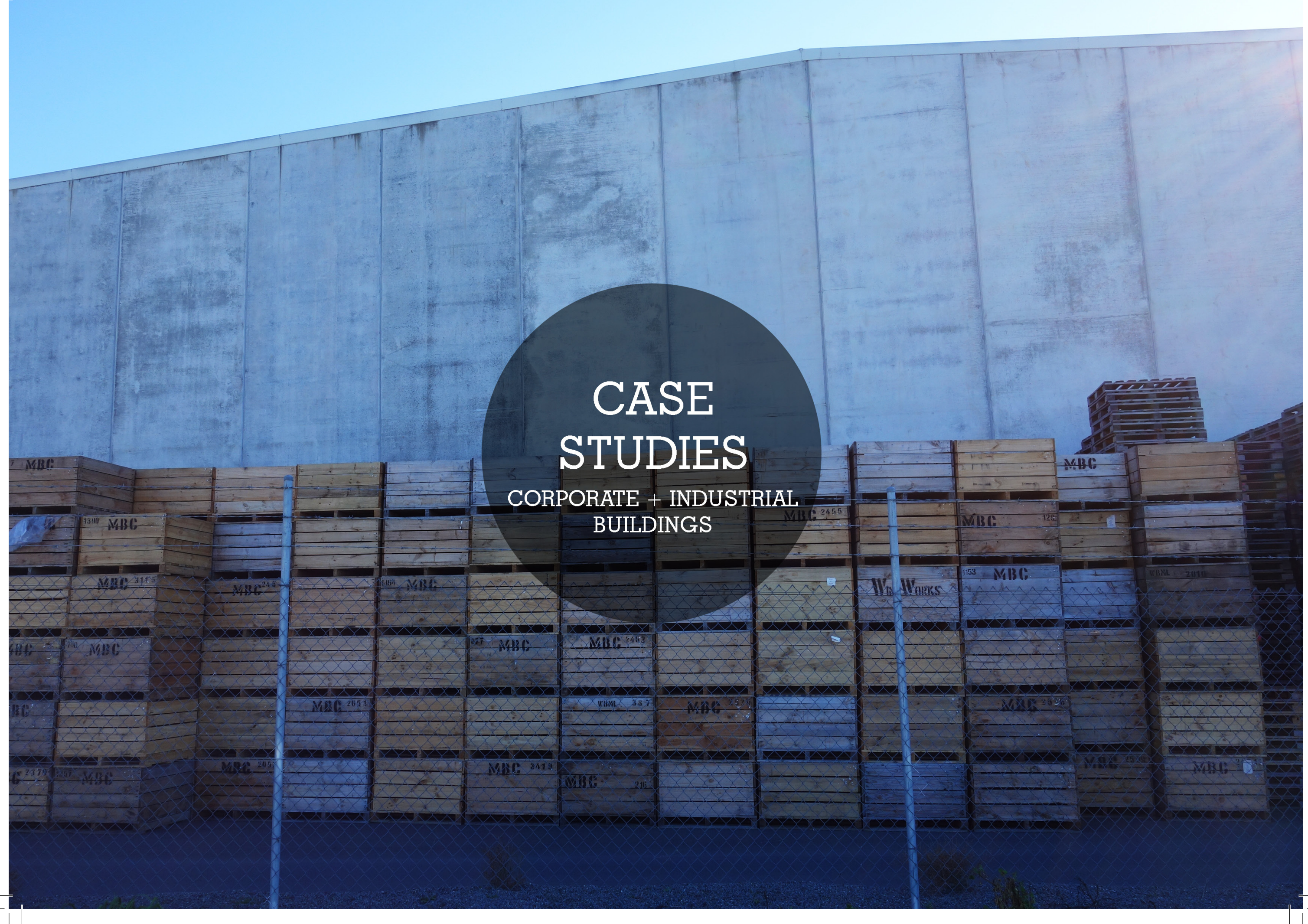




\subsection{CASE STUDIES - Corporate + Industrial Buildings}

This chapter investigates how architects have shown a companies corporate identity through a building. The case studies investigates functionalist corporate buildings, the experience provided by corporate buildings and what design elements are used to influence these. 
The ultimate goal of corporate architecture is to create designs that contributes to the goal of establishing a corporate identity. "Corporate architecture, is an integral part of comprehensive corporate identity program, conveys a firms core ideas and belief systems by simultaneously providing a symbolic dimension, an emotional experience, and an organisational structure that help strengthen corporate values on a perpetual level" (Klingmann, 2007, p. 259). The architectural solutions that communicate these elements however should not compromise the overall function of the building whether it is a production building, administration office or retail outlet.

So how has architecture been translated previously and how has it changed. Originally corporate architecture was associated with Sullivan's 'form follows function' which became linked with the functionalist movement (Raffelt, Schmitt, \& Meyer, 2013). This view was further strengthened with the emergence of architects such as Gropius and Van der Rohe who heavily promoted functionalist design. Economic changes in society was the reason that corporate architecture didn't remain in the functionalist classification. The economy moved from production to consumption into the "experience economy" (Pine \& Gilmore, 1999), as did marketing shifting from features and rewards into "experiential marketing" (Holbrook \& Hirschman, 1982) (Schmitt, 1999). What resulted was a shift from 'function' to 'form' (Klingmann, 2007) with the architecture emphasizing the brand of the company through experience rather than the functionality of the program (Bahamon, Canizares, \& Corcuera, 2009). 
These categories have the ability to speak the company's corporate identity in two different ways but what would happen if these two were to be combined in a hybrid format of corporate architecture [fig 3.1]? The pursuit of creating the corporate identity requires a balance between form and function and the key architectural elements that do this can be investigated through analysis of built examples.

There are a number of architectural focus areas/elements that a company may choose to focus on in the design of its buildings. For example an element that is at the forefront of many functionalist designs is the use of glass because of its transparent properties. The need for quality lighting conditions in specific work areas combined with a human's basic desire for natural lighting has led to manipulation of transparent properties of facade systems.

Another element is the use of representation to make connections between other marketable elements of the company and the building design itself. Representation has less of an impact on the functional and logistical aspects of a building but can be a useful tool for influencing the materiality, shape of architectural components such as structure or materiality and in particular is a vital too implementing a company's specific brand values.

\section{BUILDING CONCEPTS}

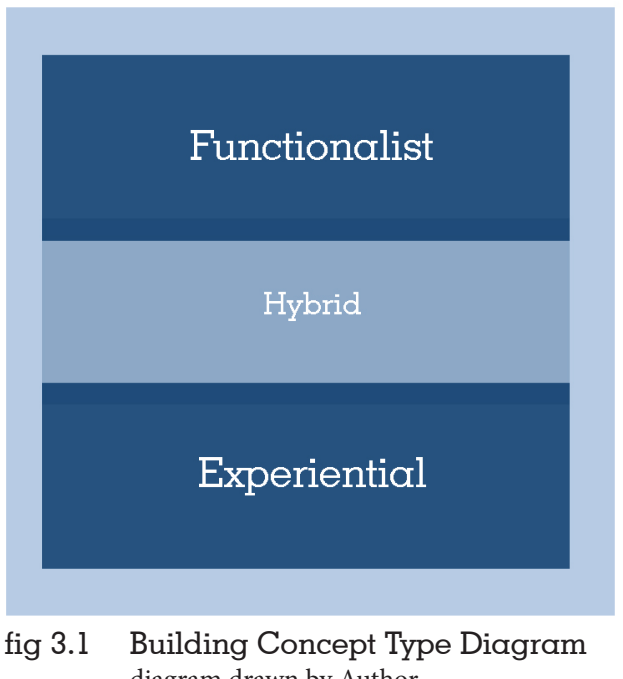

diagram drawn by Author 
fig 3.2 AEG Logo Image credit to B Dedieu-Anglade

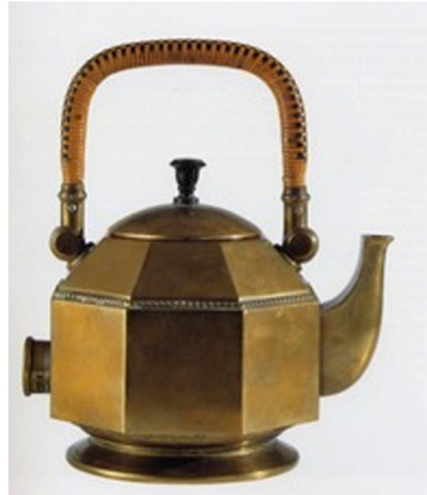

fig 3.3 AEG Electric Kettle Image credit to T, Lee

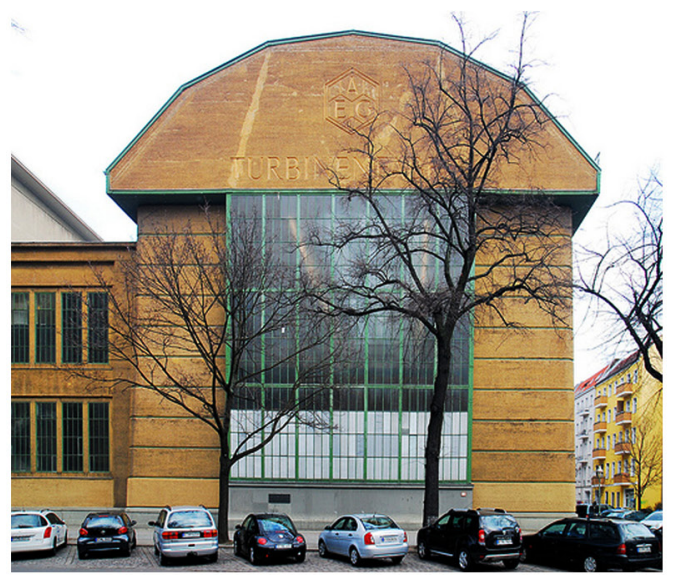

fig 3.4 AEG Turbine Factory Frontage Image credit to Wolfsraum

Behrens was the pioneer for realising the relationship between industrial design and architecture leading him to become one of the main discoverers of corporate brand identity (Guenther, 2012). Originally at $A E G$ there was inconsistency between the designs and the way the products worked so in 1907 AEG hired Peter Behrens as an Artistic Consultant (Boztepe, 2012).

Using fundamental design principles and universal elements throughout the company's portfolio Behrens created consistency to ultimately clarify the company's vision. With AEG the products spoke a similar language. His designs underlined the strength and reliability of the company, which was an important image for a company that was trying to be the leader of market domestic appliances (Boztepe, 2012). The key principle, within which architecture was included, stated the importance to "solve the conflict between the design of technical appliances and their architectural surroundings, within which they will be used" (Buddensieg, 1979, p. 38). The design of the AEG turbine factory was based on "achieving structural equality between design methods involved with the technical products and the company buildings" (Buddensieg, 1979, p. 38) [fig 3.2, 3.3, 3.4]. What this means is that Behrens was trying to translate design elements of AEG products into the architectural elements of the buildings so that AEG's products could be installed easily and aesthetically into the company buildings and factories. This essentially created a theme that was consistent throughout AEG's company. 
The turbine factory demonstrates how Behrens was able to negotiate between the architectural elements and the brand identity displayed in the products. 'Just as with the AEG products, it was his intent to introduce an artistic design idea, which went beyond the satisfaction of these requirements, into the designs" (Messedat, 2005, p. 44). Structurally Behrens modified the aesthetic of the space frame, Behrens "smoothed the structure bundling the forces in a massive system of stressed double-frames, which was visually clearly taken from the fine structures of cast iron structures" (Messedat, 2005, p. 44) [fig 3.5, 3.6]. This demonstrates a strong use of representation using the structure as a bridge between building and product. It is possible that the structure [fig 3.5] makes reference to the octagonal shape of the early AEG Logo [fig 3.2] while the materiality reflects that of the cast iron bodies [fig 3.6] of AEG's electric fans and other cast iron products [fig 3.3]. The structure he incorporated was not any old structure, rather a structure that referenced the strength and quality of AEG's cast iron formwork.

However this interplay between product properties and architectural elements could be considered as only half of the negotiation. There is much speculation from architectural critics that the turbine is a building that solely demonstrates a purist interpretation of 'form follows function'. Historian Pevsner only perceives the buildings functional devotion declaring it "the most beautiful building erected up to that time" (Pevsner, 1986), echoed by Banham who believes the design is successful due only to industrial necessity (Banham, 1978). Contemporary critic Behne describes the building as "devoted to function" free from ornament and decoration (The Modern Functional Building, 1996).
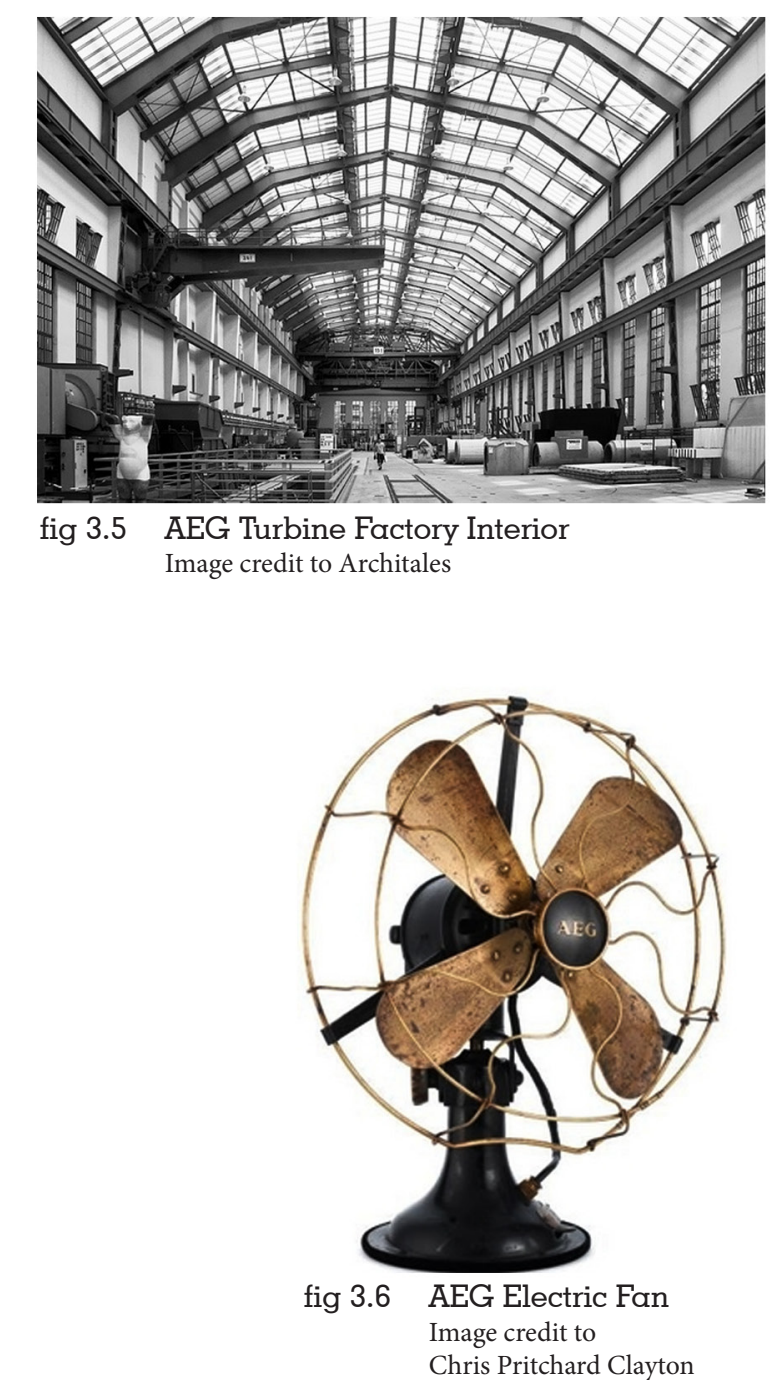
In terms of the arrangement and planning of the building the design is extremely functionalist as explained by Behrens.

"The spatial arrangement grows out of the organization of the production process. Clear layout, ease of interchange and forward movement of products and unhampered mobility of tools, machines, or trucks require open, uncluttered, well-lit halls (...) It is therefore recommended that staircases and elevators be moved to the exterior" (Quoted in Behne 1996[1920], p. 107-108).

However in terms of other architectural rudiments as explained previously the structure and form may have been designed by Behrens with an ornamental aspect that subconsciously is intended to make reference to the corporate values and brand identity of the company. "He (Behrens) did not accept the industrial manufacturing process and the constructive requirements for buildings as absolute dictators of design, but left room for artistic elements" (Messedat, 2005, p. 45). Why else would the roof form be structured as it is, why not a flat or a generically pitched roof be utilised [fig 3.3]?

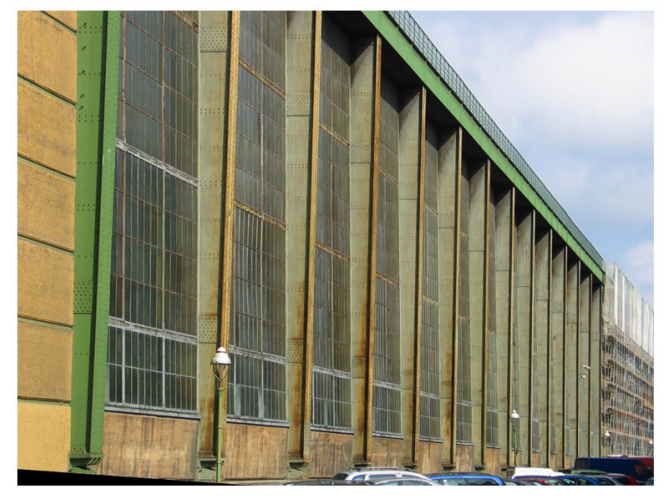

fig 3.7 AEG Turbine Factory Facade Image credit to Jose Garcia
This question raises more questions to the functionalist argument. Why pitch the transparent facades rather than have them perfectly vertical [fig 3.7]? By doing this; to a functional mind-set all that is achieved is a loss of work space. Behrens himself acknowledges a functional reason for having the facades "Since light is a prerequisite for good work, factory buildings should have large window openings; they should dominate, control the surface of building and lend support in their effect as windows" (Peter Behrens in 1920 Quoted in (Behne, 1996, pp. 107-108). But also emphasizes the 
manipulation of them as well to seem friendlier to the public. "For this reason they should not seem like large holes in the wall but appear flush with the outer wall, giving the exterior friendly appearance" (Peter Behrens in 1920 Quoted in (Behne, 1996, pp. 107-108). Glass facades were not common at the time, so these big windows were revolutionary. Behrens needed light in the factory, but he did not make the wall completely transparent or vertical as this might seem daunting and effect the public image of the company as a producer of user-friendly, reliable house hold products [fig 3.8]. This built example showcases competing aesthetic and functional elements expressed through architecture and product

$$
\text { OLIVETTI FACTORY IN POZZUOLI } 1950 \text { - } 1955 \text { (Functionalist) }
$$

The Olivetti Factory in Pozzuoli represents a story of a business owner with the help of an architect attempting to change the trend of the working class in Italy post-war. Historically workers from the south would migrate to the north and work in factories in northern Italy.

Adriano Olivetti and the architect Luigi Cosenza created a typewriter production factory using architectural elements of functionality, flexibility, technical systems and the beautiful landscape that the factory was sited in to convince workers to stay in southern Italy to work. Cosenza recognised the poor working conditions of factories in the North and how they impacted negatively on the land. "The horrible monotone constructions of the past (factories) defiled the environment wherever they were

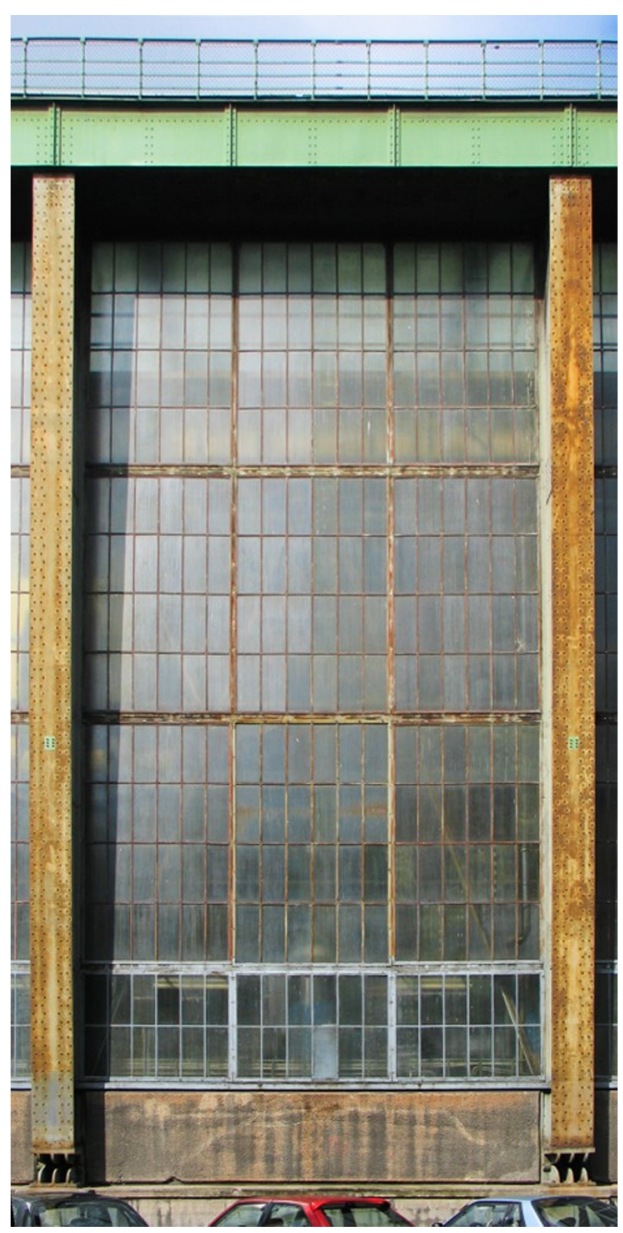

fig 3.8 AEG Turbine Factory Facade Image credit to Jose Garcia 


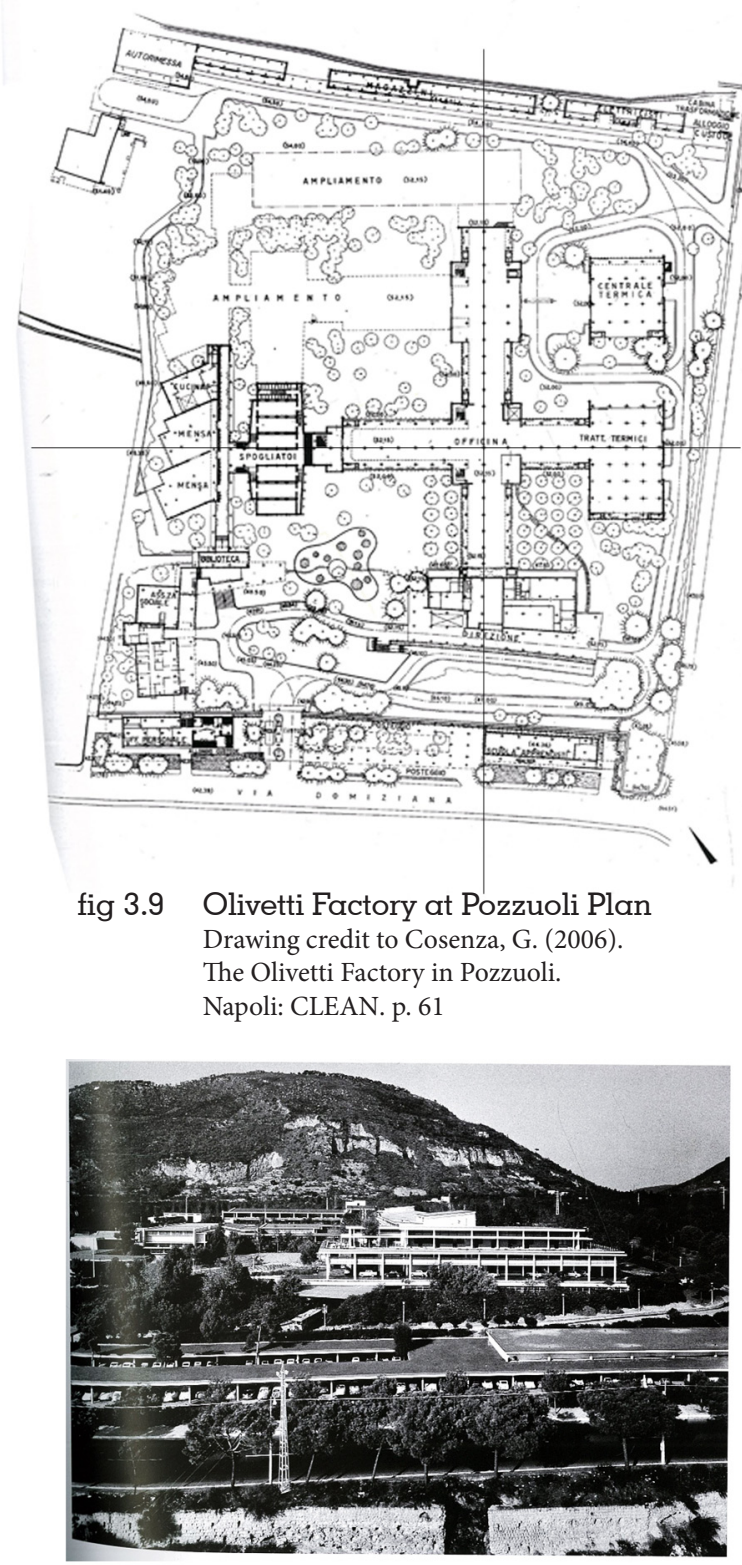

fig 3.10 Olivetti Factory at Pozzuoli Image credit to Cosenza, G, p. 93 found, and working conditions were truly inhumane" (Cosenza, 2006, p. 30). To counter this Cosenza focussed on the layout of the building to increase light and air flow through the building. Similar to Behrens, the working conditions were based around allowing for 'good work' but Olivetti further understood the concept as he recognised the relationship between a happy work place and productivity. "Modern industrial architecture tends to organise spaces to allow the maximum light and natural air in the working areas, so that dirt, the enemy of machines, can be seen and thereby increase the efficiency of the equipment and economic return" (Cosenza, 2006, p. 30). To allow for light to all workspaces Cosenza incorporated two perpendicular axis used that not only followed the functions of the factory, but ensured quality working conditions [fig 3.9].

This linear approach not only worked systematically for typewriter manufacturing but in contrast to a tall imposing factory also kept the building flat and more appreciative of landscape features [fig 3.10]. The intention of the building was to "eradicate the discrepancy between man and machine, and therefore between worker and factory" (Messedat, 2005, p. 36) and this was done by organisation of the buildings, focussing on the relationship of the buildings to the exterior and the use of usable roof surfaces and terraces [fig 3.11]. "The 'anti-industrial' appearance is above all achieved through the usable roof surfaces and terraces that are orientated towards the gulf of Naples" (Messedat, 2005, p. 36) [fig 3.11]. Fortini writes that Cosenza's success is the design is that "its modern forms fit unobtrusively into the landscape" which considering the area was noted for its beautiful open landscape and historical associations was notable (Fortini, 1958) [fig 3.10, 3.12]. Using this philosophy Cosenza was able to 
communicate his vision of the ideology the 'happy factory' by creating quality working conditions while ensuring a functional environment (Messedat, 2005).

Other additions included a programmable addition in the form of a housing settlement. Fortini writes that because of the development of the industry a small population influx occurred resulting in the need for housing (Olivetti, 1958, p. 102). To deal with these stresses an additional housing settlement was constructed at Pozzuoli as "an organic complement to the industrial plant" (Fortini, Olivetti, \& Bigiaretti, 1958). This extension to the factory demonstrated Olivetti's commitment to their company beliefs.

What the factory at Pozzuoli demonstrate is a commitment to the companies beliefs from the architect through an intense architectural examination. Cosenza employed a "quasi-cinematographic sequence of fifty-seven sketches" (Cosenza, 2006) to produce a design that was able to employ all of Olivetti's principles evenly and fairly [fig 3.13]. It communicates the importance to ensure that one aspect of the brand identity does not inhibit another and to re-design to ensure quality throughout the focus architectural elements.

\subsection{BMW HEADQUARTERS 'THE FOUR CYLINDER' 1970-1973 (Functionalist)}

BMW World in München, Germany has set the benchmark for corporate architecture in the last fifty

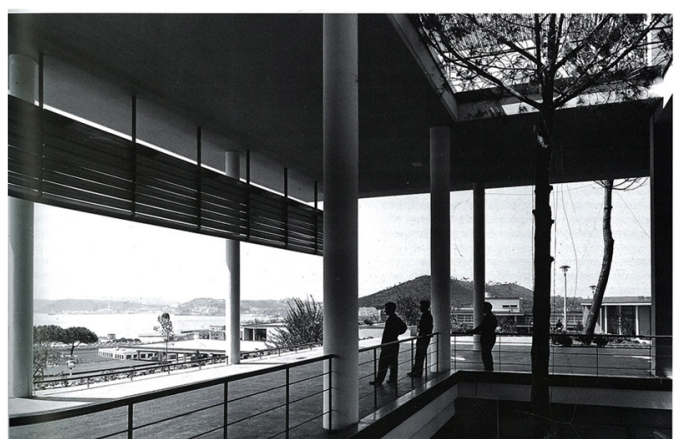

fig 3.11 Olivetti Factory at Pozzuoli Image credit to Cosenza, G, p. 145

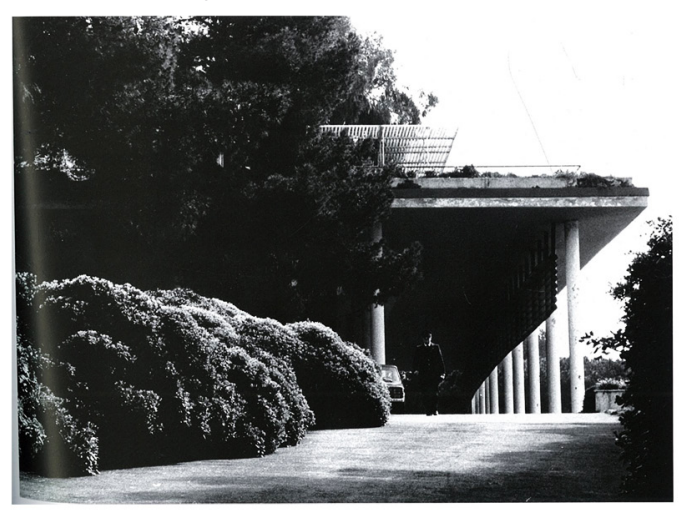

fig 3.12 Olivetti Factory at Pozzuoli Image credit to Cosenza, G, p. 187

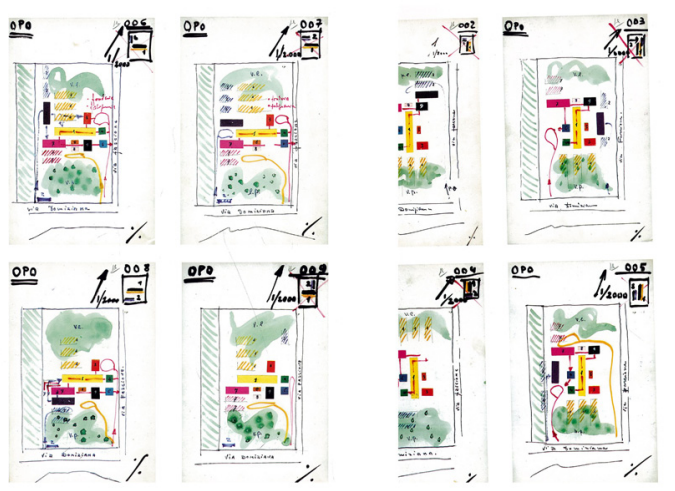

fig 3.13 Luigi Consenza's Drawings Drawing credit to Cosenza, G, p. 39-53 
years starting with the construction of their headquarters known as the four cylinder (1970-1973). The focus areas of this building was the functionality, flexibility and aesthetic of the building as well as its relationship to the other BMW constructions to come on the rest of the site.

The buildings functionality is largely involved with the plan form of the building that is reminisce of a cruciform plan with four semi-circles connected (Messedat, 2005). This layout was selected because it "not only demonstrated a very economic use of space, but also documented the then state-of-the-art method of construction" (Messedat, 2005, p. 67) where the individual floors were suspended using prestressed concrete tubes. This construction technique allowed the four areas of the 'cloverleaf' to be column free strengthening the idea of functional but mostly flexible office space aiming to encourage company transparency and a flow of ideas free from office hierarchy [fig 3.14]. Schwanzer describes his intentions of the circular office space, "The circular-shaped office spaces generate an outer skin with mental stimulation for deep, peripherally thoughts" and "concentrated polar training of concentrated ideas flowing together" in "circular space gathered together like a community" which "unites people in a circle with the same opportunities without preference" (Schwanzer 1975, p. 114). The key component of the building however is how the Architect Schwanzer was able to successfully bring together the identity of the BMW Company with the architectural elements.

fig 3.15 Extruded Plan Outcome Drawing credit to Schwanzer, Karl $\mathrm{p} .115$

The building does this through the design of the cloverleaf plan because when drawn up into a high rise the form of the building appears to visually represent connections to the cylinder's of an engine 
[fig 3.15]. Raffelt writes that the 'four cylinder' is representative of it brand core by envisioning the companies brand heritage, 'automotive engineering' (Architectural Branding as Brand Communication, 2011) while also making the connection of the building being a functionalist building while still having representational qualities. "[T]he BMW headquarters (...) is a functionalist office building, visually representing the components of automotive engines" (Marketing Form and Function, 2013, p. 202). Herbst states that the 'four cylinder' is symbolic of the core elements of a car manufacturer these being the cylinders of a motor (Herbst \& Maisch, 2009). The strength of the idea lies in the dual reasoning of the cloverleaf plan and the way Schwanzer used it to promote the company to the public while ensuring functional, efficient space for workers.

Another significant element that contributed to this representation quality of the building was the aesthetic of the exterior facade. Considering the large surface area in a high rise it was important for Schwanzer to produce something that demonstrated what values BMW as a car manufacturer intended to be known for (rather than a large simple face that may emote solidness and immovability). Raffelt writes that "on a concrete level, the architecture (BMW headquarters) may express brand values by means of its design language" meaning that the building resembles the qualities that BMW feel important in their products company identity and structure. (Architectural Branding as Brand Communication, 2011 , p. 248). To express these ideals Schwanzer developed a unique facade design that creates a texturous yet consistent facade that articulates a degree of complexity and technical expertise [fig

3.16]. "The sloping window openings and their parapets, which slope in the other direction, create a

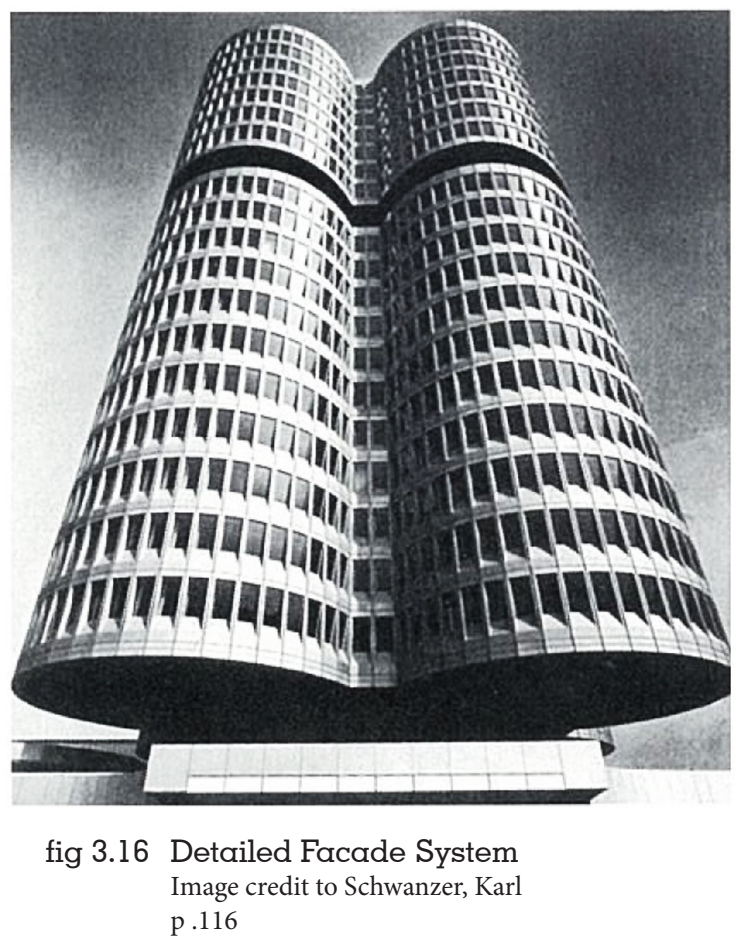




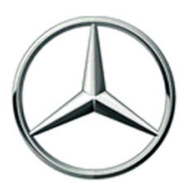

fig 3.17 Mercedes Logo Picture credit to Mercedes Benz International Website

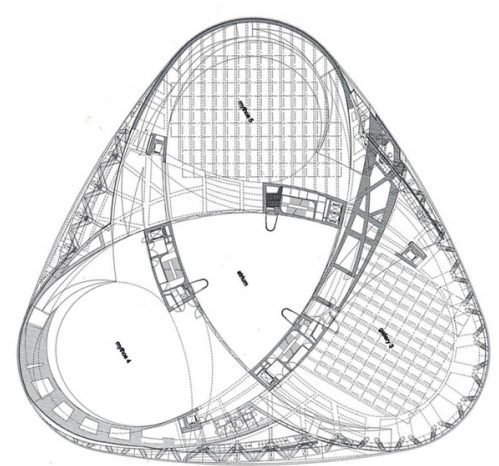

fig 3.18 Mercedes Benz Museum Plan Picture credit to UNStudio, 2007

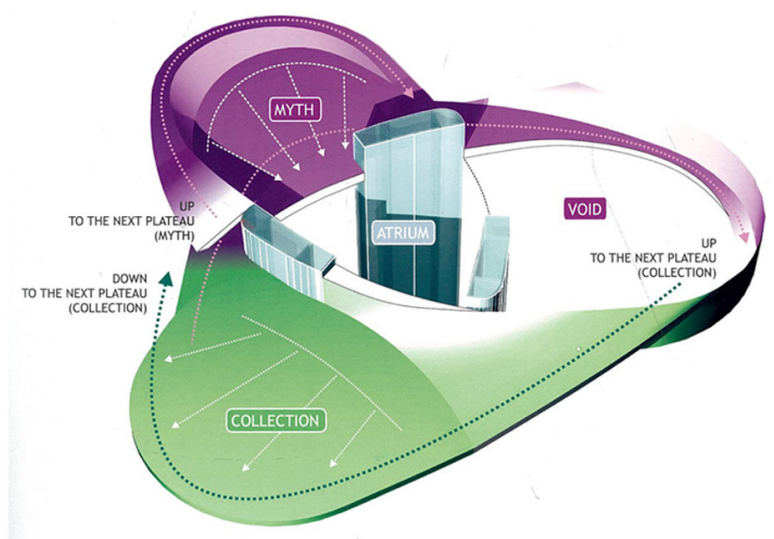

fig 3.19 Mercedes Benz Museum Plan Picture credit to UNStudio, 2007 p. 33 play of light and shadow on the plastic skin" (Messedat, 2005, p. 68). What results is an elegant facade that contributes heavily to the representation of the Four Cylinder and also the corporate identity of the company.

3.04 MERCEDES BENZ MUSEUM 2001-2006 - (Experiential)

The automobile industry predicted early the communicative potential that public buildings could have in the experiential sense of corporate architecture. This competitive environment forced manufacturers to start producing building designs that could emote brand identity and focus on an experience to distinguish themselves from other companies (Herbst \& Maisch, 2009). What resulted was an influx of strong experiential corporate designs. Of these two in particular were able to generate clear mental images associated with the company's products (Herbst \& Maisch, 2009). Another automobile company that were able to successfully employ experiential corporate architecture was Mercedes-Benz. MercedesBenz most well-known building is the Museum designed by UNStudio. The programme of the building allowed the museum to recount 125 years of Mercedes-Benz's influence on the automobile industry demonstrating their values of authenticity and fascination (Raffelt, Littich, \& Meyer, 2011).

UNStudio have designed the plan of the museum using the Mercedes-Benz logo. The three forms arranged in a triangle around a central interior space resembles the trefoil shape. Both Klingmann 
"The sense of motion extends from the urban context into the museum interior like a centripetal force, while the trefoil shape alludes to the Mercedes trademark" (2007, p. 30) and Raffelt, Littich, \& Meyer "Its shape is based on a trefoil and is similar to the logo, which is also partitioned in three parts" $(2011, \mathrm{p}$ 251) make references to the plan form being drawn from the Mercedes-Benz logo itself [fig 3.17, 3.18, 3.19]. This use of representation to inform the plan demonstrates an interesting way of incorporating the visual identity into the planning of the design. In this way of designing the building is certainly not a functionalist type of corporate architecture.

The six floors of the museum are connected via two different pathways gradually ascending up ramps in a smooth road like fashion by-passing 6 exhibition spaces [fig 3.21]. The pedestrian pathway is described by Klingmann as a "seemingly endless loop of the pedestrian promenade designed to provide a variety of viewing options" (2007, p. 30). Klingmann explains the 'double helix' as purposely designed to create shifting positioning for the visitor as they progressed through the museum by-passing interior and external viewpoints, contrasting scales of spaces and cross referencing between displays (Brandscapes: Architecture in the Experience Economy, 2007) [fig 3.20]. The design of the building is relatively nonfunctional however this appears to be intended. Raffelt explains that the challenging construction techniques and overall design of the helix is unique and demonstrates Mercedes-Benz's innovativeness (Architectural Branding as Brand Communication, 2011, p. 251).

The facade of the building as in the 'four cylinders' uses a unique system that is designed to speak fig 3.20 Mercedes Benz Museum Plan Diagram credit to

UNStudio

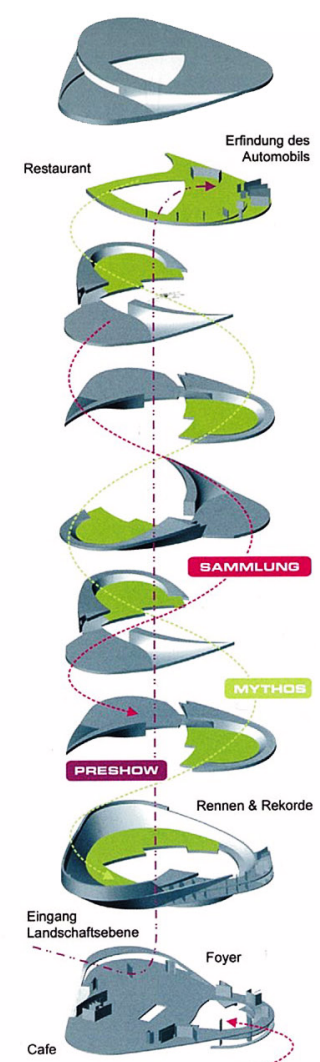

fig3.21 Mercedes Benz Museum Plan Image credit to UNStudio
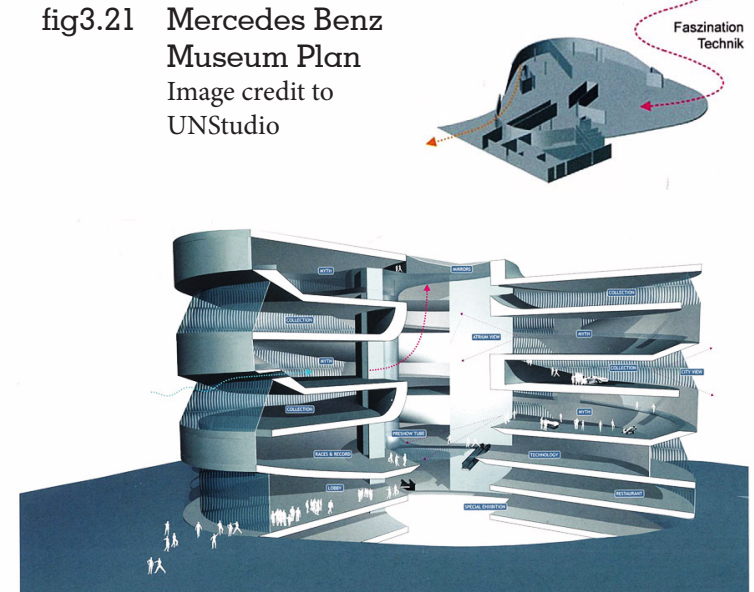


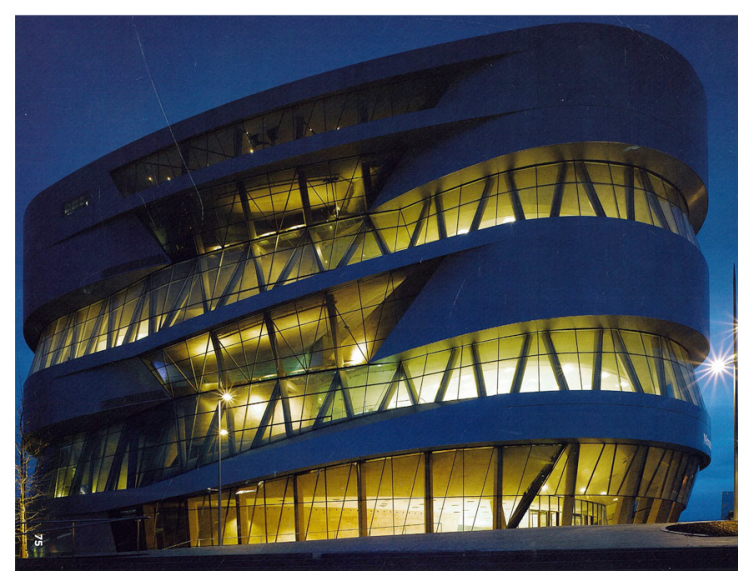

fig 3.22 Mercedes Benz Museum Plan Image credit to UNStudio, 2007 p. 74

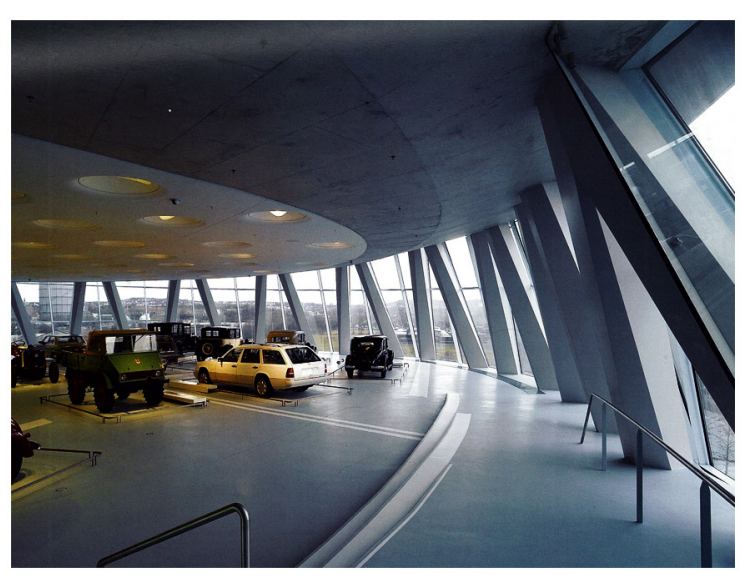

fig 3.23 Mercedes Benz Museum Plan Image credit to UNStudio, 2007 p. 43
Mercedes-Benz's brand values however demonstrates no apparent functional benefits. The continuous loop of materiality is intended to create a sense of speed and continuity. "Both in form and organisation the Mercedes-Benz Museum expresses velocity, which is conveyed by the sinuous lines defining its streamlined envelope" (Klingmann, 2007, p. 30) [fig 3.22]. The glass exterior packaging is supported by a concrete columns that like the structure in the AEG turbine building make reference to the visual identity of the company. "The columns dividing the glass facade are arranged at oblique angles, which reinforces associations with the label" (Raffelt, Littich, \& Meyer, 2011, p. 251) [fig 3.17, 3.22, 3.23]. In this case however it is to the logo not the product. Overall the facade is intended to communicate Mercedes brand values of quality, elegance and exclusivity (Raffelt, Littich, \& Meyer, 2011, p. 251).

\subsection{BMW WELT - 2007 (Experiential)}

The most recent addition to BMW world is the BMW welt designed by Coop Himmelb(l)au and built in 2007. The building experience itself is supposed to be an expression of BMW's brand values. The Welt is a form of experiential corporate architecture that demonstrates a clear expression of the brand's values (Raffelt, Littich, \& Meyer, 2011). These values although different to the 'Four Cylinders' are concurrent with BMW's strive to 'shape the future' of car design and maintain its image as a provider of premium products and services for individual mobility. "Dynamic is conveyed by the tornado-like shape of the building, challenging by the deconstructivist, cutting-edge architectural style, and cultured by the idea 
of cultural space" (Raffelt, Littich, \& Meyer, 2011, p. 251). To achieve this the architectural elements focused on are the aesthetics, functionality, product display, technical systems, energy consumption and the site which the Welt is a part of.

Himmelb(l)au has selected an analogy of a tornado to express dynamics. The visual analogies of a tornado covered by clouds is intended to stimulate customer perception of dynamism and challenge - the core brand values of BMW (Feireiss \& Kwinter, 2007) [fig 3.24, 3.25]. A definition of dynamics makes it easy to understand why BMW and Himmelb(l)au selected it as a design driver because of its association with positive, ever changing qualities.

The changing shapes of the glass window panes held between the steel mesh expresses variable speeds of movement and a contrast of tenseness and relaxation of the twisting form [fig 3.25, 3.26].

"The network of heavy steel sections with constantly changing mesh sizes, shifted as if in a twisting movement, really does create a dynamic that cannot be felt anything as powerfully anywhere else in the building" (Werner, 2009, p. 11). The analogy of something known for rapidly spinning, fierce, fast moving and powerful movement is a strong way to express the dynamism of the company, their products as well as the harshness of the industry environment and the struggle it requires to remain top of the market.

The statement by Raffelt, Littich, \& Meyer mentions using deconstructivism to create discomfort and

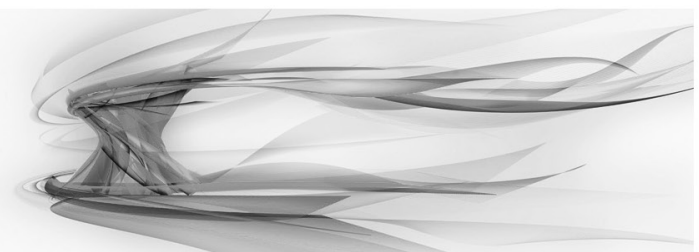

fig 3.24 BMW Welt Image Image credit to BMW Group

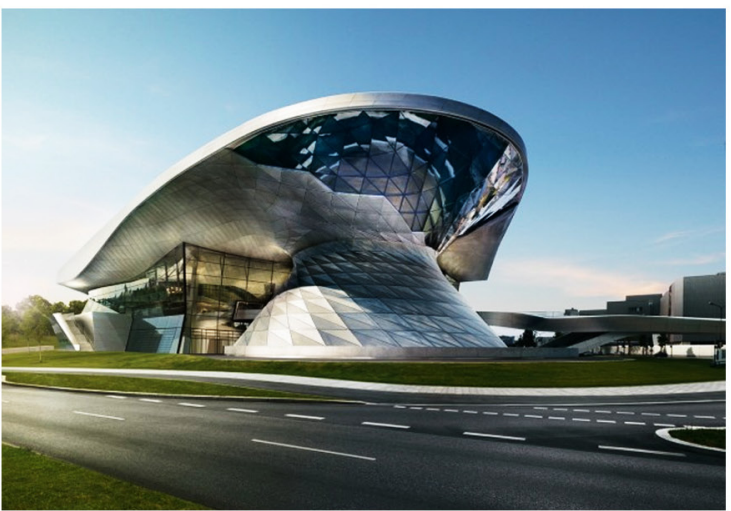

fig 3.25 BMW Welt Tornado Image credit to Morfae

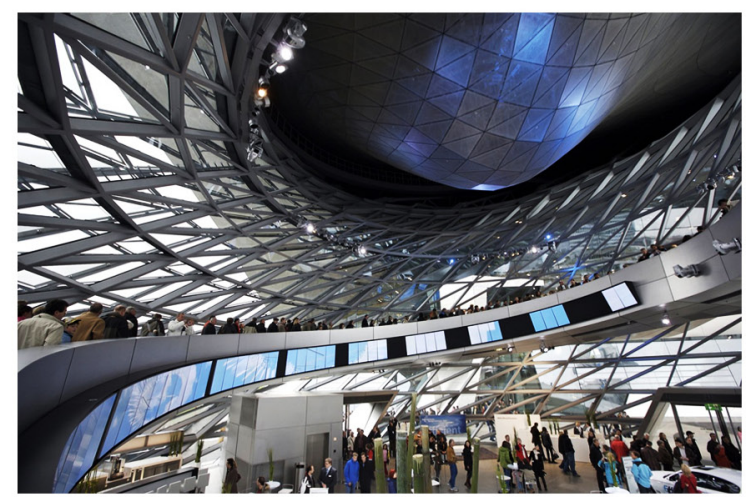

fig 3.26 BMW Welt Interior Tornado Image credit Coop Himmelb(1)au 


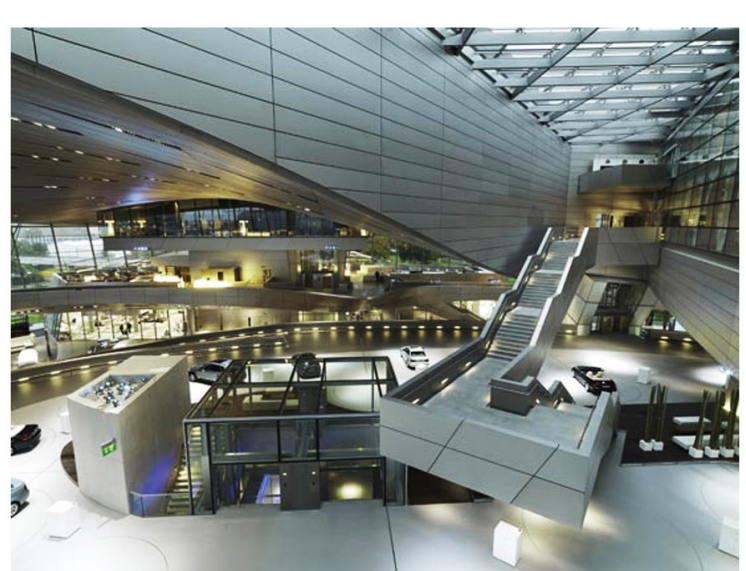

fig 3.27 BMW Welt Deconstructivism Image credit Tom Williams, BMW

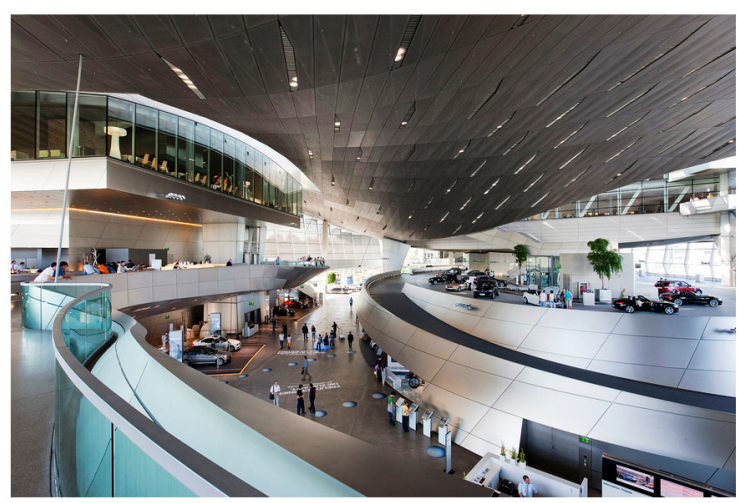

fig 3.28 BMW Welt Vehicle Collection Image credit Neccesary Indulgences confusion. The relationship between the deconstructivist approach with the analogy of the tornado makes reference to BMW's slogan; power is nothing without control. BMW in the exhibition space of the building uses it to create a 'challenging' space that epitomises what BMW faces and overcomes in the search for new and improved vehicle technologies. Werner describes the interior space touching on the challenge of bringing together humans with vehicles.

"The inserted buildings with their sheet-metal planning populate the enormous hall like archaic landmarks [fig 3.28]. They are focused on the holy of holies, that is to say the place for the solemn union of man and car, which seizes the central point under the clouds" (Werner, 2009, p. 13)

The use of deconstructivism as a design style creates an experience that at times seems to work together extremely well and at other times disjointed [fig 3.27].

Within the gigantic hall of the interior disjointed buildings work together to create a symbolic relationship between the car and the person. The central idea of the exhibition of the space is the vehicle collection handover where using experience the building attempts to tie together the owner and the brand [fig 3.28, 3.29]. "The central feature is the staging of vehicle collection: the handover to their new owners of around 45,000 cars annually is transformed into a highly emotional and sensory experience through the symbiosis of architecture and service, which binds the customer to the BMW brand long-term" (Herbst \& Maisch, 2009, p. 7). In this case BMW have realised the potential of experiential architecture as a marketing ploy. Purchasers of BMW's at the Welt are not likely to forget such an impressive experience 
and are far more likely to inform other potential buyers.

The vehicle collection provides an excellent experience to BMW vehicle purchasers however the Welt has not stopped there. The idea of creating a "cultured by the idea of cultural space" (Raffelt, Littich \& Meyer, 2011) [fig 3.30] has been used to entice people who may not be intending to buy a car rather experience the many other activities and services such as a Michelin Star Restaurant that the building provides. Werner describes the building as a 'modern hybrid' because of its flexibility surrounding program despite its focus goal of selling cars (Werner, 2009). The flexibility of the program is not only dictated by the spaces but also the time frames that the different programs operate at.

"[I]n future the most of the building is to be open day and night, in other words freely accessible without charge for admission or fear of entering for all those who want to enjoy the diverse cultural and communicative palette offered by the building over and above solemn vehicle handovers" (Werner, 2009, p. 11).

The program of the BMW Welt is designed to bring in the public as well as people coming to purchase cars. "In addition to its primary function as a delivery centre, BMW World is a tourist destination" (Klingmann, 2007, p. 27). The way the exhibition room works with the car presentation platforms above the mall space puts an emphasis on a consumers purchase leaving the visitors with a taste of what it would be like to purchase a BMW.

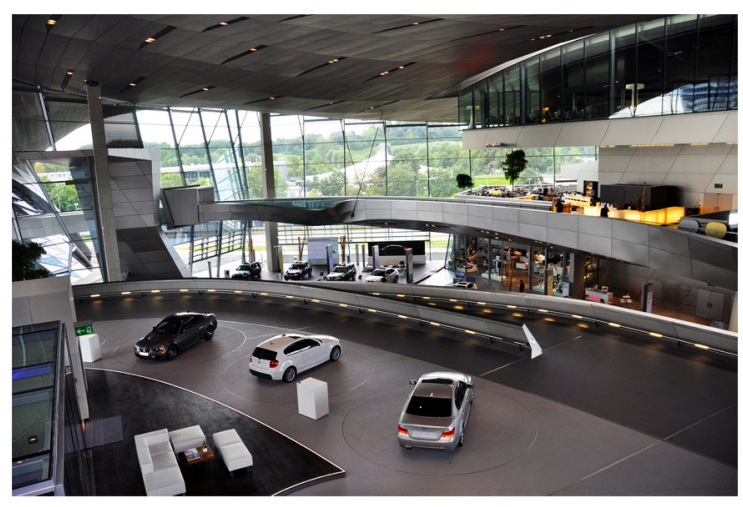

fig 3.29 BMW Welt Vehicle Collection Image credit Neccesary Indulgences

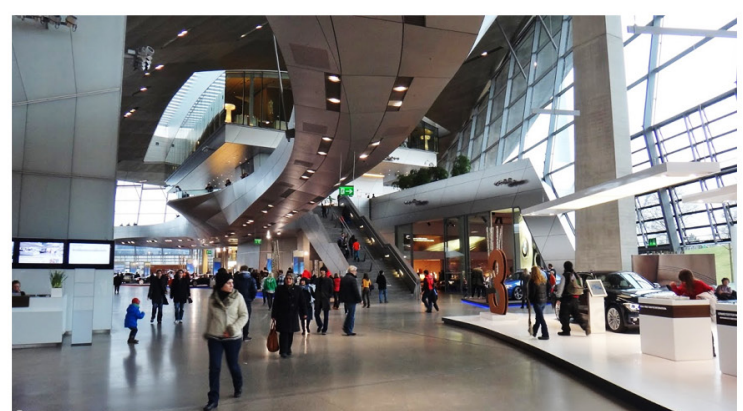

fig 3.30 BMW Welt Cultural Space Image credit Matt van Vuuren 
3.06 AUTOSTADT - (Experiential)

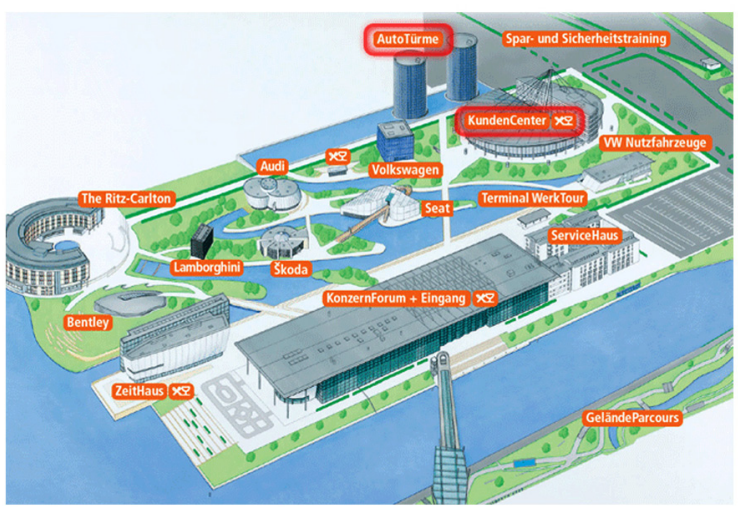

fig 3.31 Autostadt Masterplan Image credit Hot Water Drive

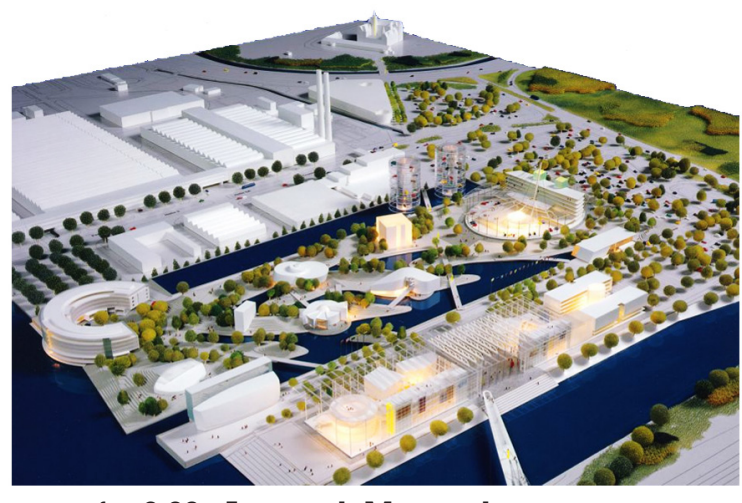

fig 3.32 Autostadt Masterplan Image credit Henn, Gunter

The Autostadt was designed by Gunter Henn for Volkswagen in partnership with Wolfsburg. The reason for Wolfsburg's involvement was that the city is working on re-branding its city to promote its qualities as a tourist destination rather than as an industrialised city (MacKeith, 2005, p. 57). The 25 Hectare vehicle 'theme-park' complex is located directly adjacent to the VW factories and was drawn from American branded theme parks Patton explains how the connection came about.

"A top Volkswagen executive Otto Ferdinand Wachs, visited Las Vegas and Disney World in 1997 to examine the two current American specialities: theme parks and branding. What resulted from Wachs' trip was a corporate city revealed in 2000 under the name Autostadt" (2000 p.124) [fig 3.31, 3.32].

Herbst and Maische outline that at the time Volkswagen perceived a lack of brand awareness due to the companies multiple brands owned (2009). Skoda, Seat, Audi, Bentley, Bugatti and Lamborghini are among the car companies owned by Volkswagen. What resulted was confusion of what the Volkswagen brand stood for (Herbst \& Maisch, 2009). With the backing from the city Volkswagen had the chance to bring together the brands into a large urban tourist setting focussed on 'Automotive Mobility'.

The urban scheme of the Autostadt along with use of pavilions and buildings was designed to emote four key values. "The Volkswagen Group's goal in the Autostadt is to enable its customers to experience the 
brand values through spatial representation; these values include quality, performance, sustainability and customer proximity" (Herbst \& Maisch, 2009, p. 5). The buildings house a museum, showrooms, corporate forum, car delivery centre, theatres, restaurants, luxury hotel, shops and pavilions dedicated to each of the companies sub brands to emote these specific qualities (Klingmann, 2007).

Through these programmes and architectural imagery the idea of the Autostadt is it leaves a unique experience on the customer that leaves fond memories particularly those who purchase a car from the 'place of birth'. The collection occurs at "one of the two 48 metre high towers, which can be seen from afar and have become a landmark of the Autostadt" (Herbst \& Maisch, 2009, p. 6) [fig 3.34]. The towers can be explored in a panoramic glass lift that also transports vehicles to the ground to be test driven or bought [fig 3.33]. The lift provides insight into these high rise parking garages and the building also has a viewing platform on the 20th floor that looks over Wolfsburg and the rest of the Autostadt (Autostadt, 2014). The handover occurs on a representative stage intended to make the experience all the more special. (Herbst \& Maisch, 2009).

To communicate the sub-brands eight pavilions were constructed at the Autostadt each representing their own brand values. "In addition to exhibitions and events on all aspects related to cars and mobility,

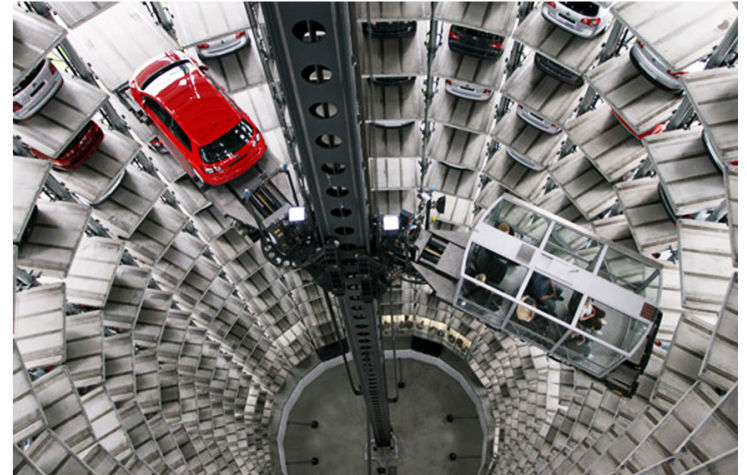

fig 3.33 Autostadt Car Garage Towers Image credit AUSmotive

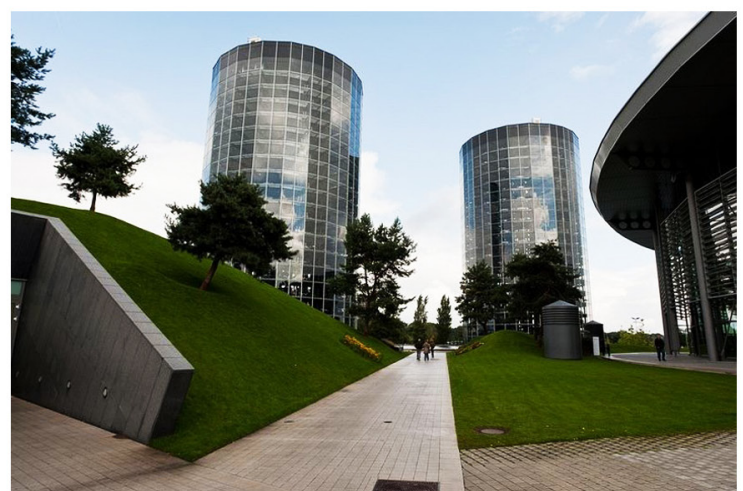

fig 3.34 Autostadt Car Garage Towers Image credit Piximus visitors are introduced to and familiarised with every brand belonging to the Volkswagen Group in a separate dedicated pavilion" (Herbst \& Maisch, 2009, p. 6). Allingham describes the impressiveness of the Autostadt pavilions "the brands are embedded in, and speak through, the elegant design of the 


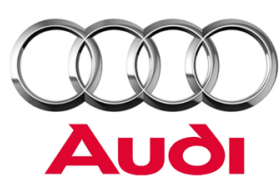

Alumium Facade representative of innovative materials use by Audi in car design, Exhibitonal spaces inside

Vigorous Masculinity, Display of strength through dark

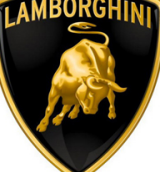
Italian temperament, Strength

cuboid form
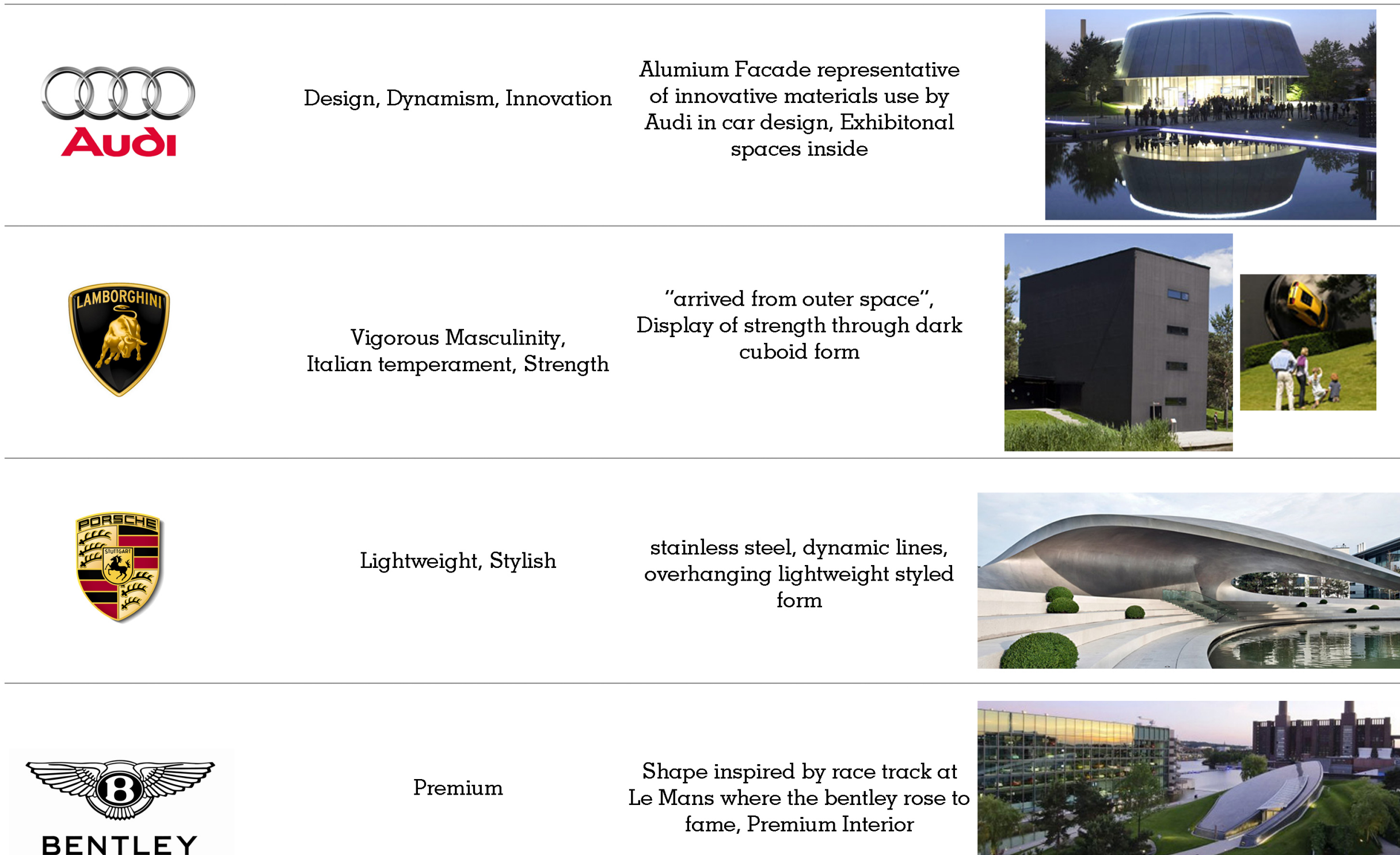

Lightweight, Stylish

stainless steel, dynamic lines, overhanging lightweight styled

form

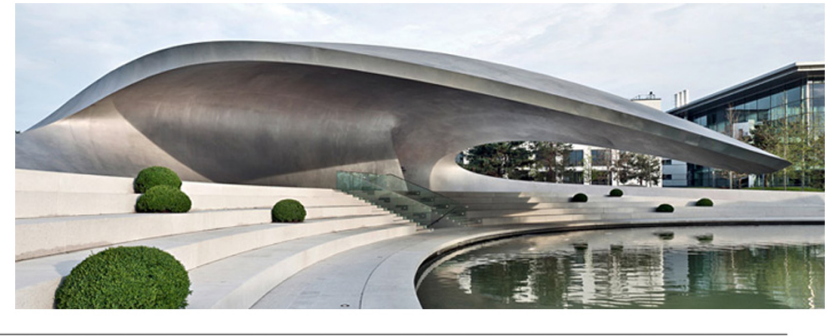

Shape inspired by race track at Premium Le Mans where the bentley rose to fame, Premium Interior

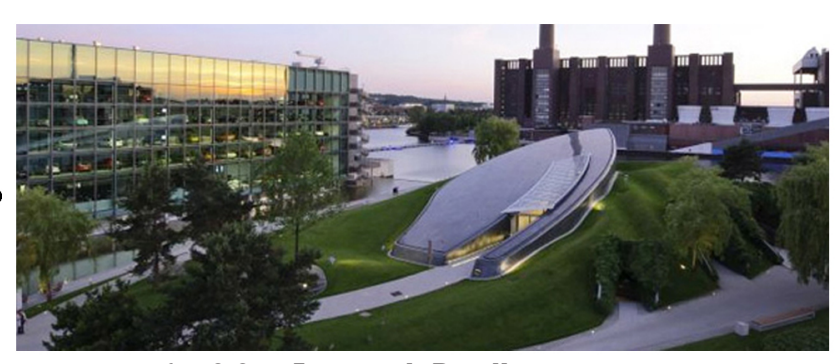

fig 3.35 Autostadt Pavillions 


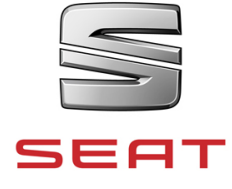

Mediterranean Vitality, Temperament, Passion,

Strength, Athleticism

Bounded by land and water imitating the geography of

Iberian peninsula, sensuously curved sculpture

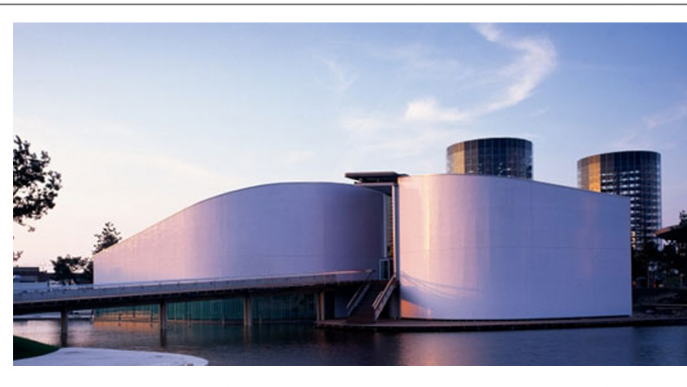

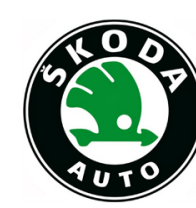

Human Touch 'Simply Clever'
Embraces the brand values of "Human Touch" and "Simply Clever". Inside four experiential spaces

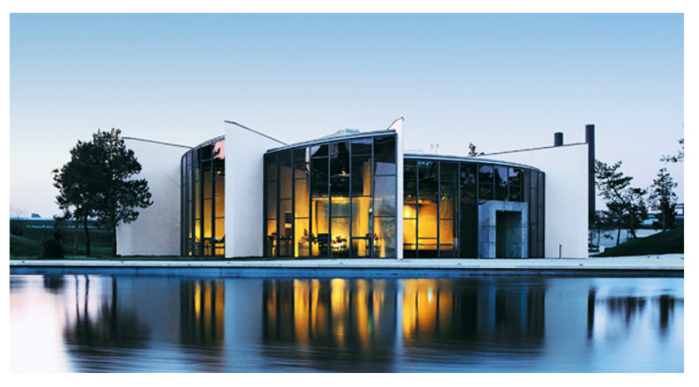

700000 LEDs on its outer skin wraps itself around the sculpture and illuminates it in every conceivable colour.

\section{Volkswagen}

\section{Diversity}
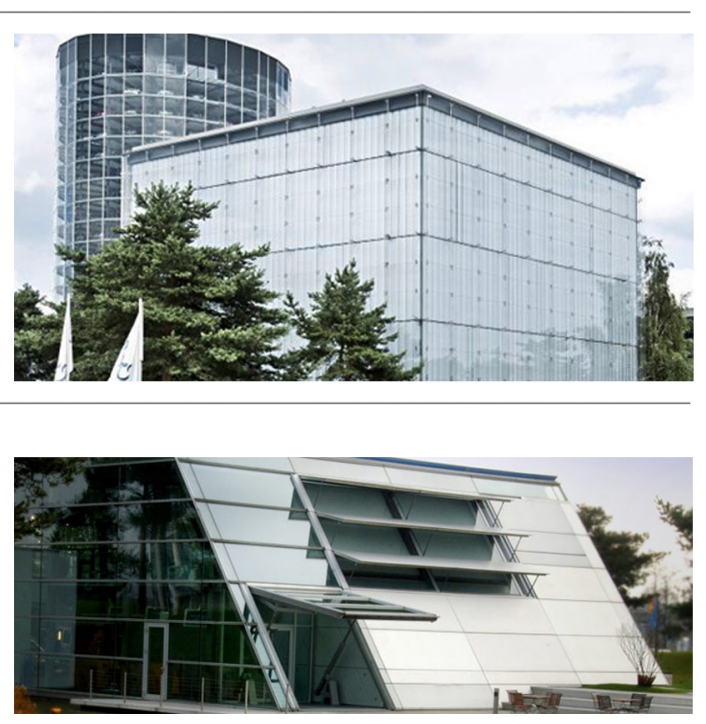

fig 3.36 Autostadt Pavillions Images Credit to Autostad 
interior and exterior of each pavilion" (2009, pp. 917-918) going on to mention the absence of any logos or other visual identity that could signal what brand is associated with which pavilion.

From the table above it is clear to see the many varying brand values working against one another resulting in various architectural forms. Klingmann is extremely critical of the Autostadt's pavilions.

"While the architecture reflects the symbolic value of each automobile brand in a very mundane and prosaic manner, it hardly seizes the opportunity to engage people through the kinds of unique, evocative, multidimensional messages that are prevalent in many of VW's advertising campaigns" (Klingmann, 2007, p. 263).

Klingmann feels the connection is merely visual and does not represent Volkswagens overall brand identity as a 'people's brand' with a lack of interactional experience involved with most of the pavilions. "Similarly, the theme parks pavilions are completely detached from the surrounding landscape; they are self-referential logos that neither engage the visitor on an experiential level nor connect to the surrounding context of the city" (Klingmann, 2007, p. 263). In fairness it is not easy for some of the luxury brands to interact with all demographics. It is also possible that this lack of connection with the city scape was intentional by the architect along with Wolfsburg intending for the Autostadt to step away from the production side of the automobile industry and glamorise the trade into a tourist friendly environment. 
Klingmann continues to criticise other architectural forms within Autostadt in particular the Konzernforum designed by Henn himself. "The monumental Konzernforum, belongs to the expression of a bygone era, one based on corporate expansion and unequivocal corporate power distancing itself from the local environment and, (...) from the human scale of its visitors" (Klingmann, 2007, p. 263) [fig 3.37]. Klingmann goes on to describe the building as a "corporate cathedral" that through the use of glass and monumental spaces speaks of a "self-contained atmosphere of sterility and aloofness" which in turn dwarfs visitors and makes them feel uninvolved with the company (Brandscapes: Architecture in the Experience Economy, 2007, pp. 263-264) [fig 3.37, 3.38]. These values of power and lack of connection that the buildings emote is far from what a company that identifies itself as a 'peoples brand' wants to be associated with

With the Autostadt it appears to be a thought-provoking design project by attempting to translate so many different values to the public through buildings. There appears to be a split between critics to whether this is a successful example of corporate architecture. Gobe understands the Autostadt as a stepping stone to further branded worlds designed for customer experience and marketing purposes.

"The examples of VW suggest the degree to which the concept of corporate identity is moving

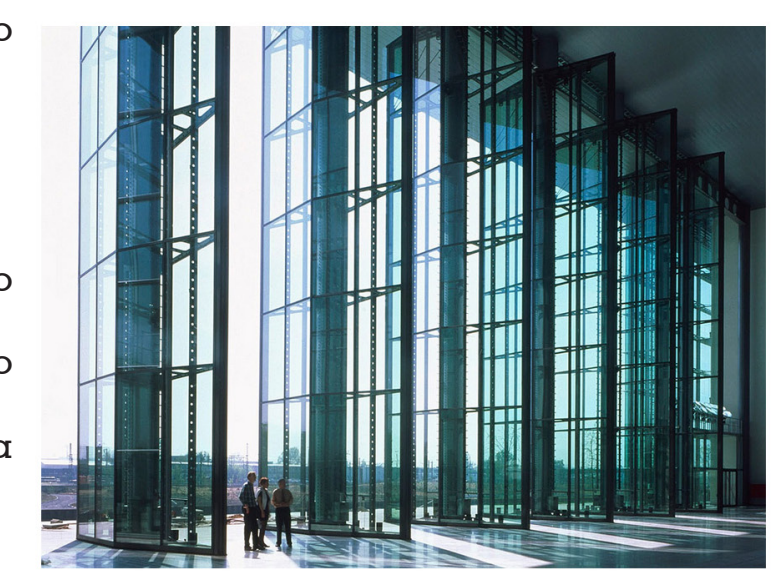

fig 3.38 Konzernforum Image Credit to Henn, G away from the 'dictated' visual identities of the past (corporate-centric identities that 'tell' us the unconditional values they represent) to the 'personal' visual identities (those designed around an emotion and whose interpretation is often different from one consumer to the next) of the present and the future" (Gobe, 2001, p. 122). 
Klingmann's argument suggests however that the Autostadt has taken this too far and Volkswagen has compromised their brand by incorporating so much different architecture to speak varying values. On one hand, the Autostadt would definitely leave a lasting impression that does promote the company, but on the other hand because of the diverseness of the architecture the company values are muddled in the visitors mind. In a sense it is successful as a promotional tool but fails to register any of Volkswagens key values within a customer due to an overload of different architectural complexities.

\subsection{SUMMARY}

Within corporate architecture there have been two main design drivers. Functionalist starts with the function and attributes company values while the experiential design starts with the corporate identity, empowers the customer experience through the architecture and adds programs. Functionalist corporate design has a rich involvement with facades because of the working conditions that this has an effect on.

In recent times there appears to be a shift towards this experiential corporate architecture. Klingmann writes that in the past corporate identity was understood as a tool to communicate a cohesive corporate expression through a straightforward, identifiable visual image. Companies nowadays must provide an experience involved with the framework of the visual identity (Brandscapes: Architecture in the Experience Economy, 2007). Representation is at the forefront of many of these designs and provides a 
proven tool to linking emotive interaction with corporate values and often provides an interesting and unique interpretation.

This interactivity however in some of these larger 'theme park' experiences seems to demonstrate $a$ lack of connection with the actual function or values of the company. "By adding theme parks, museums, and leisure venues to their car factories, automobile companies are trying to entice customers into taking a more interactive role in the production process of the merchandise" (Klingmann, 2007, p. 30). The multiple buildings appear to be spoiling the corporate identity of these large instalments. What needs to happen in these larger scale operations is a clearer style of architecture that demonstrates the values but maintains some architectural linkages throughout to ensure a cohesive corporate statement. 


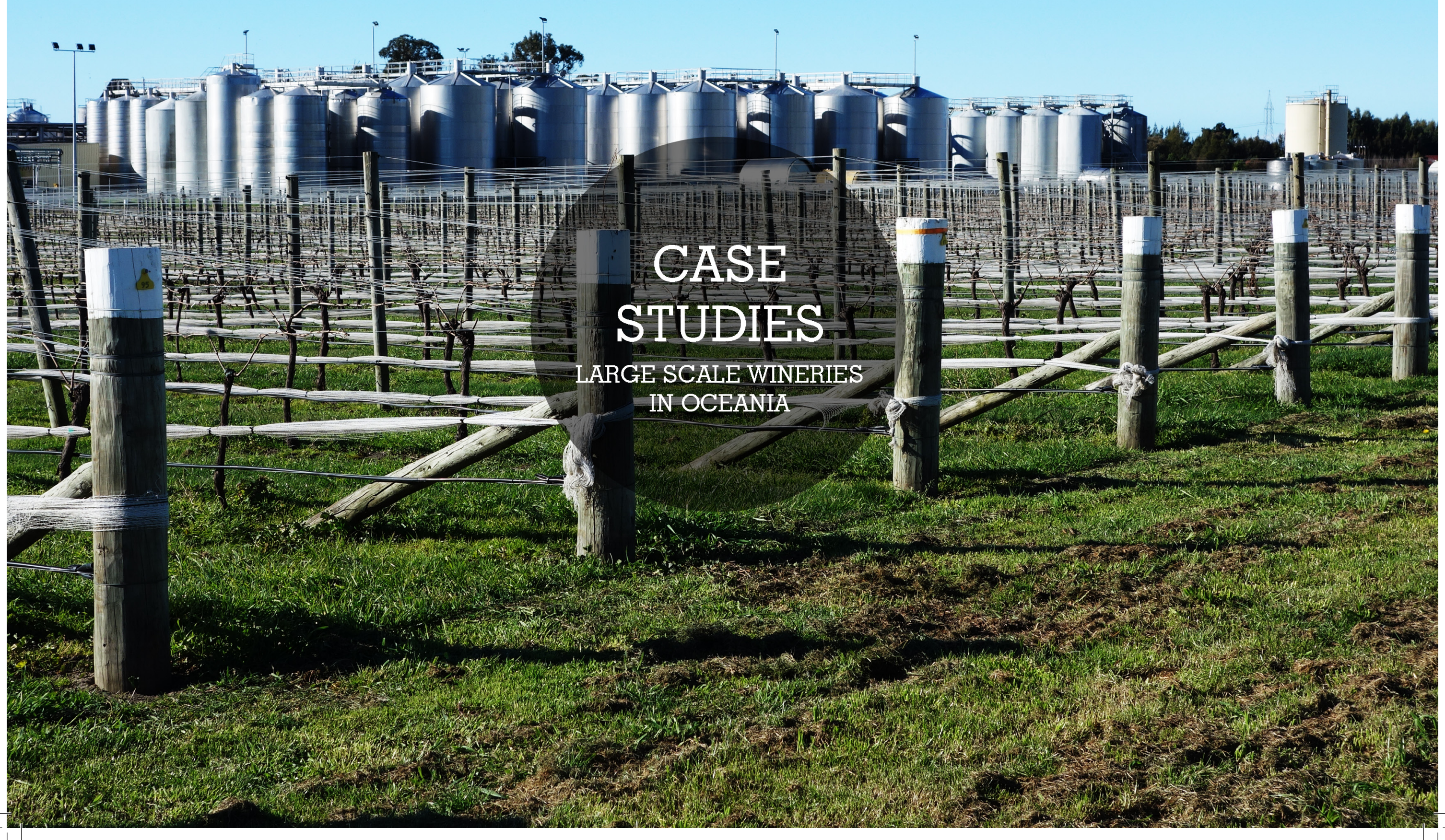




\subsection{CASE STUDIES - Large Wineries in Oceania}

This chapter analyses wineries of similar scale to Pernod Ricard and how they have decided to market themselves through their production facilities. 
Sometimes larger wineries are owned by a father company who is involved with the distribution and production of the product. Van Agtmael explains that this is because in the current wine industry to become recognised as a world class winery it requires more than, "a favourable climate, experienced vinologists, good grapes, and cheap labour; scale, sophisticated branding, good publicity, and global distribution are equally important" (Emerging Markets Century, 2007, p. 80). Examples of this in Oceania include Penfolds and Yellowtail who are owned by Treasury Wine Estates and Casella Wines respectively both based in Australia.

Both these, but particularly the example of Treasury Wine Estates with Penfolds show similarities with Pernod Ricard and Brancott Estate Wines. Treasury Wine Estates has a similar company structure to Pernod Ricard NZ. They both own a number of wineries of which one is a stand out and is far more well known. This requires a decision whether to filter in the father companies corporate values into the established wine brand. Yellowtail is significant because of the massiveness of the operation in which it functions. There are no winery production facilities that operate at this scale in New Zealand. Generally at these type of wineries that have large exports the majority of grapes are grown, produced and packaged far from the public winery experience. 
Treasury Wine Estates owns 36 wineries in Australia and New Zealand and another 16 globally (Treasury Wine Estates, 2014). Of these 36 the most prestigious is Penfolds, one of Australia's oldest wineries and named Australian Wine Producer of the Year in 2014 but also 22 other times by the International Wine and Spirit Competition (IWSC) (Treasury Wine Estates, 2014). Penfolds consists of 13 vineyards totalling approximately 1500 Hectares (The Penfolds Vineyards, 2014), although they also get grapes from over 220 vineyards and grape growers across Australia (About Our Vineyards, 2014). Penfolds operates out of two wineries. Penfold's Chief Winemaker Peter Gago (2014) describes the Magill Estates Cellar door as "the spiritual home" where Penfold and his wife first settled in 1844 (Penfolds Winemaking Philosophy). The 'Grange Cottage' uses stacked stone masonry walls with a consistent orange trim around openings and is nestled amongst the original Grange vineyard [fig 4.1,4.2]. The winery has developed over time and visitors are able to explore the historic winery on a tour. The winery features underground tunnels, historic bluestone cellars and also the Grange cottage

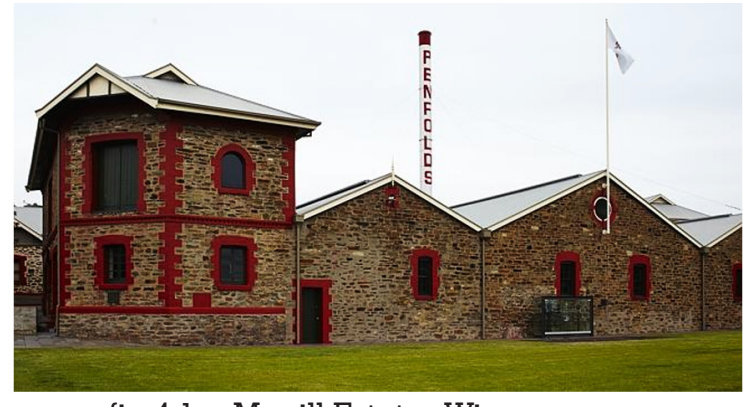

fig 4.1 Magill Estates Winery Image Credit Grant, $\mathrm{S}$.

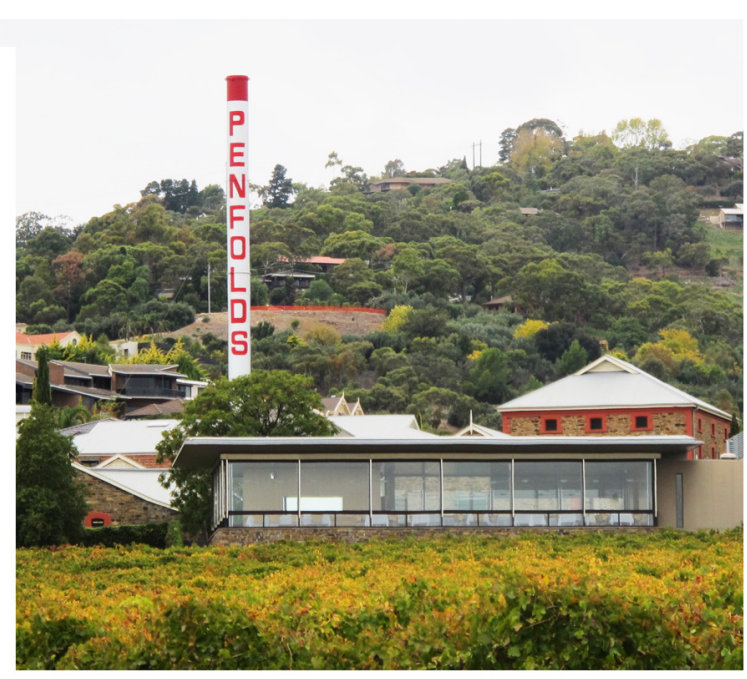

fig 4.2 Magill Estates Restaurant Image Credit to Double Dutch Oven where the founding Penfolds first lived. A contemporary extension was added in 1996 that incorporated new offices, further wine storage, revamped tasting room, and an entirely new structure housing a warehouse and restaurant [fig 4.2]. 


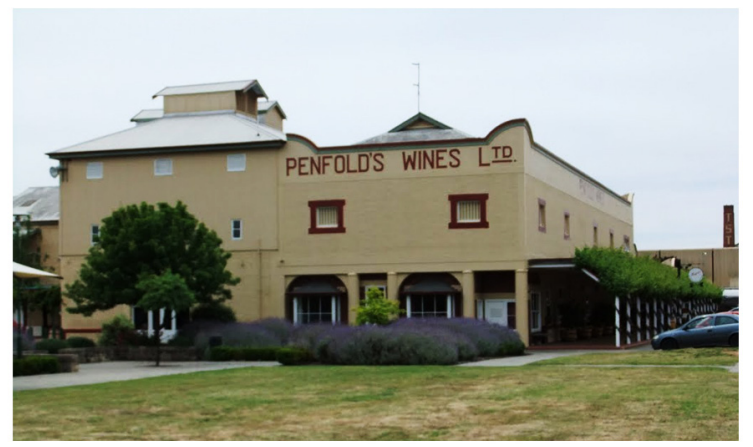

fig 4.3 Barossa Valley Winery Image Credit to Bongers, R.

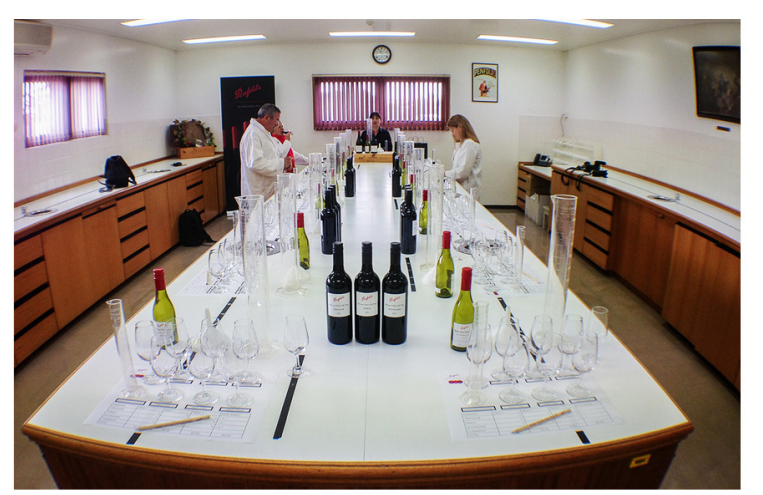

fig 4.4 Barossa Valley Winemaking Image Credit to Bouskill, D. \& Corbell, D.
4.02 PENOLDS - Barossa Valley

The Barossa Valley winery was originally built in 1911 for the purpose of expanding the Penfold business. However this site became the focal point for winery production in the 1970's as more vineyards were planted in the Barossa valley region (Penfolds, 2014). "The Barossa Valley Nurioopta winery is certainly the engine room of all things Penfolds from a wine production perspective" (Gago, 2014) [fig 4.3] Visiting this winery provides a far different experience to the Magill Estates as it provides an insight into the engine room of the Penfolds winemaking and the extensive wine barrel storage room. One of the experiential features of the winery is that guests are able to try blending their own wine from Grenache, Shiraz and Mourvedre, etc. within the Winemakers' Laboratory where upon leaving it is presented to them in a bottle (South Australia Government, 2014) [fig 4.4]. This winery is far more production based and to market this has introduced a programme that people can take part in. The experience is far more interactive and due to this is more likely to leave an impression on visitors.

\subsection{YELLOW TAIL - Yenda Production Facility}

The second example is Casella Wines located in Yenda, New South Wales. Casella Wines owns three brands most notably Yellow Tail. The total amount of vineyard hectares owned by Casella recorded in 2010 was approximately 1060 Hectares (Senior Lifestyle South Coast, 2011, p. 66). Yellowtail makes 
entry level wine which originally focussed on international sales. Within the winery in Yenda there appears to be no glamorised winery experience at all advertised [fig 4.5], the winery's sole purpose is for production and this seems to be echoed by the founder's son John Casella. "People can't be bothered by all the hype and nonsense of wine. They just want to drink it" (Yellow Tail, 2014). The winery has over 730 stainless steel fermentation tanks and storage tanks, the capacities ranging from 110,000 Litres (100 of them) to 1094 Litres [fig 4.5, 4.6]. Along with these is a barrel room that houses 5000 barrels, 4 bottling lines and 4 fruit crushers (Senior Lifestyle South Coast, 2011, p. 66). "It is Australia's largest family owned winery, Australia's largest single wine processing facility and one of the biggest wineries in the world" (Senior Lifestyle South Coast, 2011, p. 66). The architecture speaks as an industrial building with no room for an experience [fig 4.5, 4.6]. In this case it makes sense for Yellowtail to represent themselves like this because Casella originally targeted the American market and therefore an experience is irrelevant to selling the wine to overseas locations.

\subsection{SUMMARY}

These two examples represent two very different ways of marketing a company and how this has affected the design of the wineries. With reference to Pernod Ricard's vineyard area in Marlborough, a wine production facility would be required to cater for 15,000 Hectares, 10 - 15 times larger than that

of Penfolds Estate and Casella Wines respectively. Pernod Ricard who market themselves as a quality

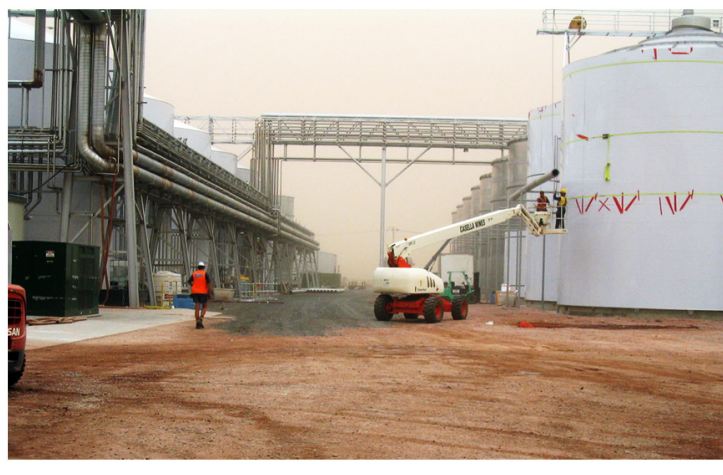

fig 4.5 Casella Winery

Image Credit to Cultivate Construction

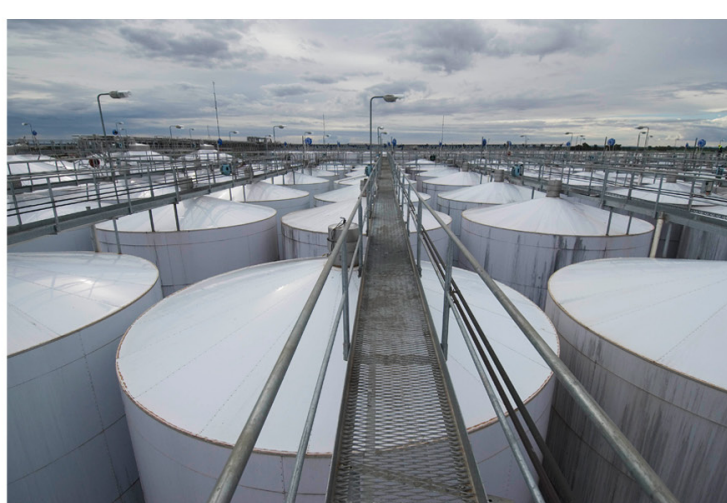

fig 4.6 Casella Winery Image Credit Truong Anh Wines and Spirits Distribution 
Wines and Spirits producer and distributor company would be more likely to present themselves in the Barossa Valley fashion attempting to involve the production with the customer experience. The Brancott Estate Heritage centre connects with the past comparable with Magill Estates already, which leaves an opportunity for Pernod Ricard to market themselves using a Barossa Valley like experience whilst incorporating the industry and scale of Casella's production facility at Yenda. 


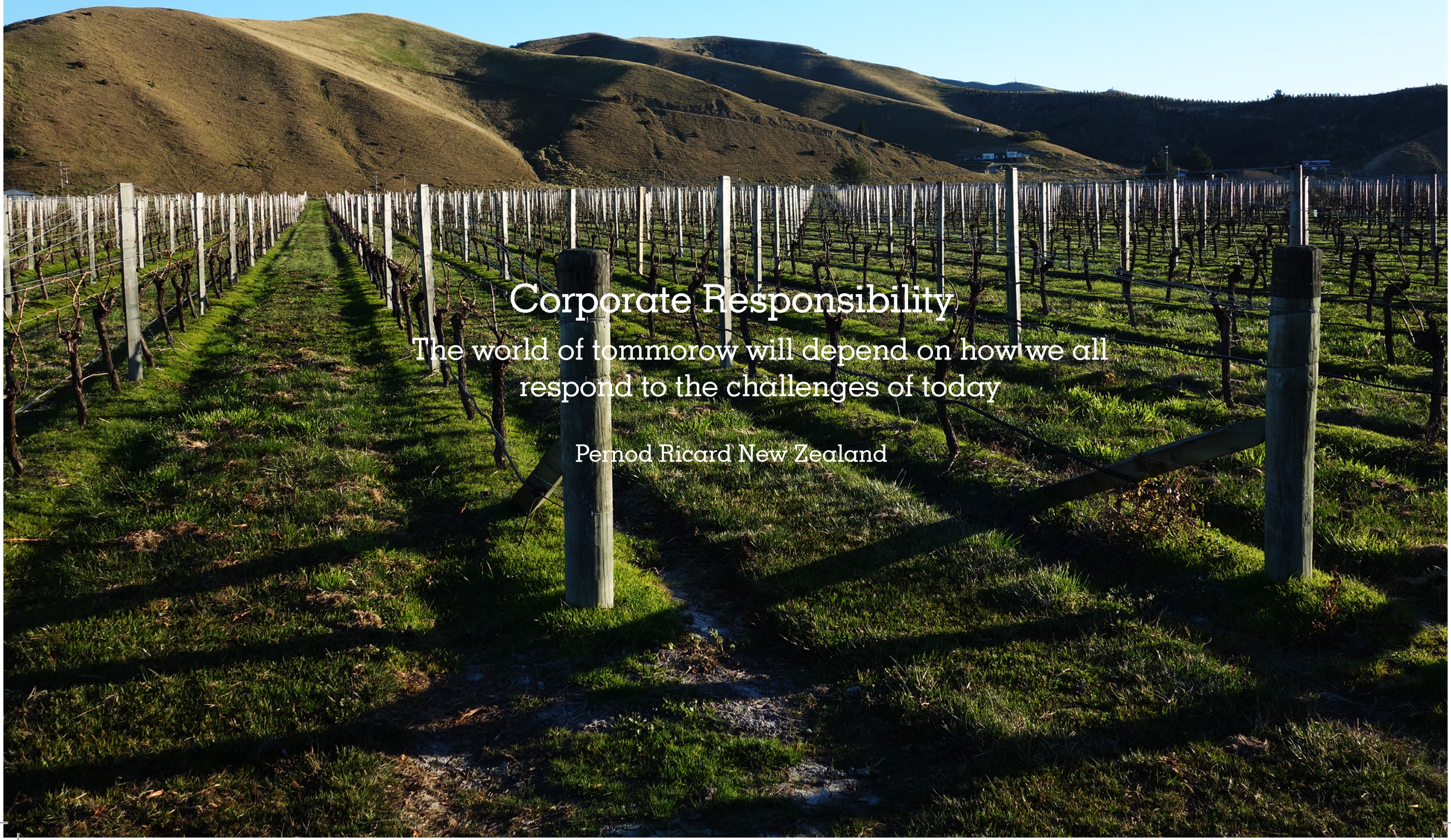




\subsection{THE CLIENT - Pernod Ricard}

The chapter introduces the client, their corporate identity and their company structure. It also investigates the site which they currently own in Marlborough. 


\subsection{COMPANY STRUCTURE}

Pernod Ricard was created in 1975 and has grown globally to become the co-leader in Wines and Spirits production and distribution.

Pernod Ricard has an extremely complex company structure to market its many wines and spirits that already have their own brand identity. To distinguish its wine range as its own category Pernod Ricard have split its five premium wines into a single unified entity; Pernod Ricard Winemakers. These five wines are Jacob's Creek (Australia), Brancott Estate (New Zealand), Campo Viejo (Spain), Graffigna (Argentina) and Kenwood (America) and are marketed by 4 companies, Pernod Ricard Australia, Pernod Ricard New Zealand, Domecq Bodegas and Pernod Ricard Pacific Travel Retail. Pernod Ricard New Zealand manages eleven wineries of which Brancott Estate formerly Montana is the most notable.

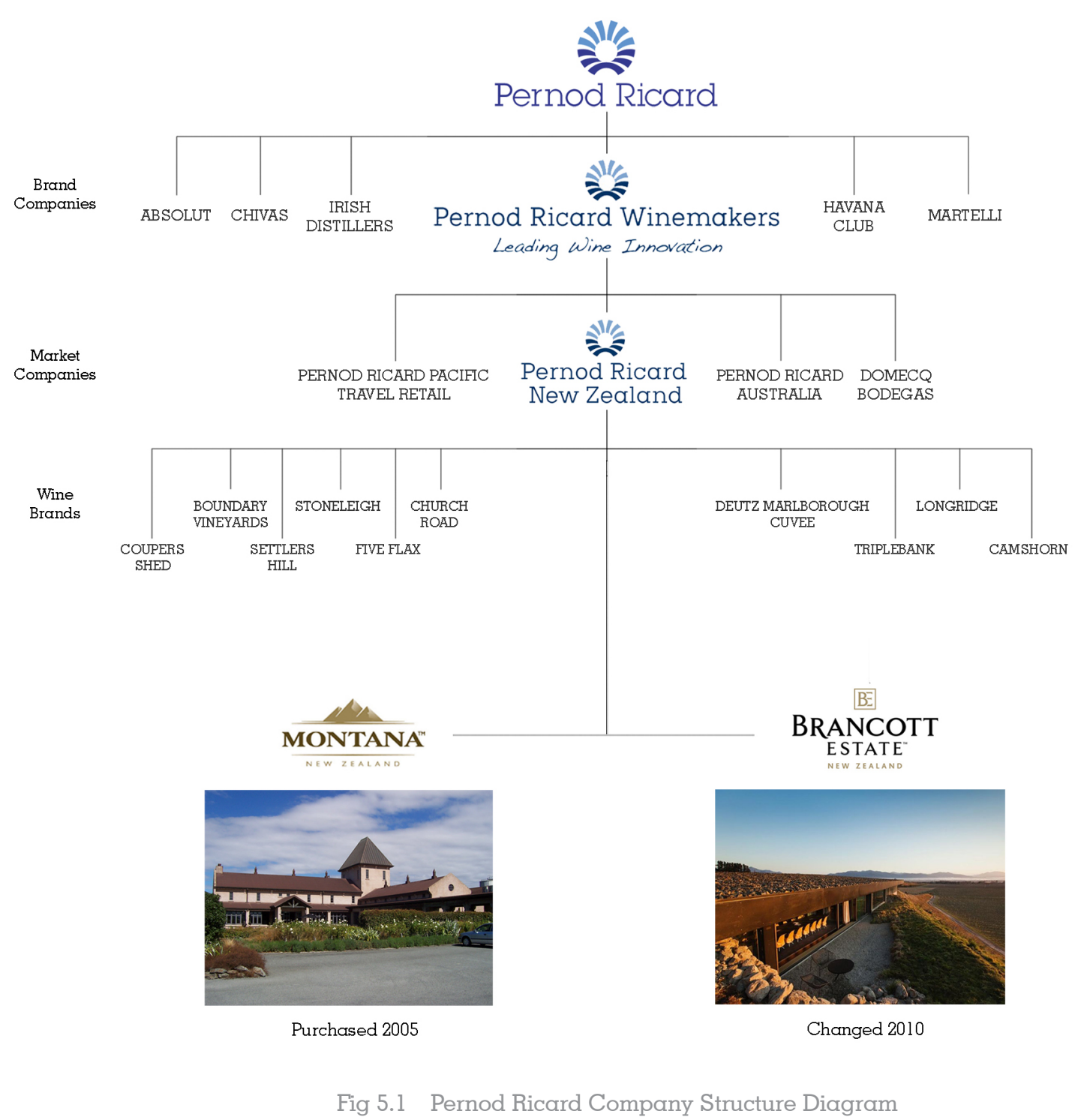

Fig 5.1 Pernod Ricard Company Structure Diagram 


\subsection{CORPORATE IDENTITY}

Pernod Ricards corporate identity filters down through Pernod Ricard Winemakers and Pernod Ricard New Zealand. Although the brands themselves may be marketed differently to maintain a strong corporate image Pernod Ricard New Zealand ought to ensure that the management of its vineyards, offices and production plants correlates with its corporate values of focussing on product, planet and people. Since these values are not embedded in the current Pernod Ricard production plant in Blenheim (formerly Montana), the design research proposes to investigate a re-development that expresses these values.

Fig 5.2 Pernod Ricard Corporate Values 


\subsection{SITE AND LOCATION}

The site on which this lies is located in Marlborough at the top of the South Island. The region is known for its Sauvignon Blanc and is the regions most produced wine (83\%), this is also Pernod Ricards flag ship wine, Brancott Estate. The former Montana winery site itself is 26.2 hectares located on State Highway 1 between Blenheim and Seddon. The site currently consists of around 40\% buildings and driveways, 30\% vineyard and $30 \%$ grass paddock. Situated against a backdrop of hills directly next to an industrial development to the west, the site

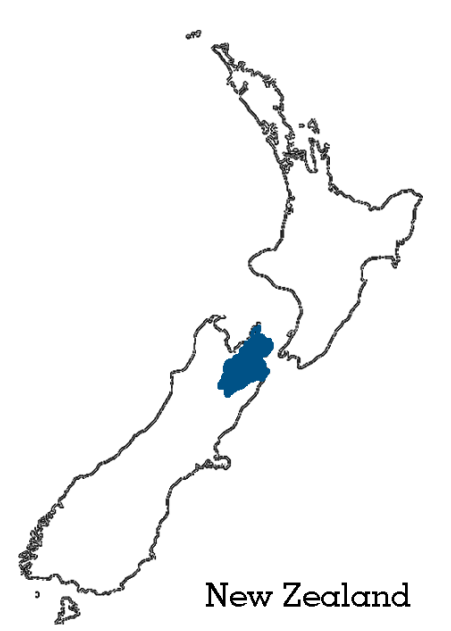

New Zealand
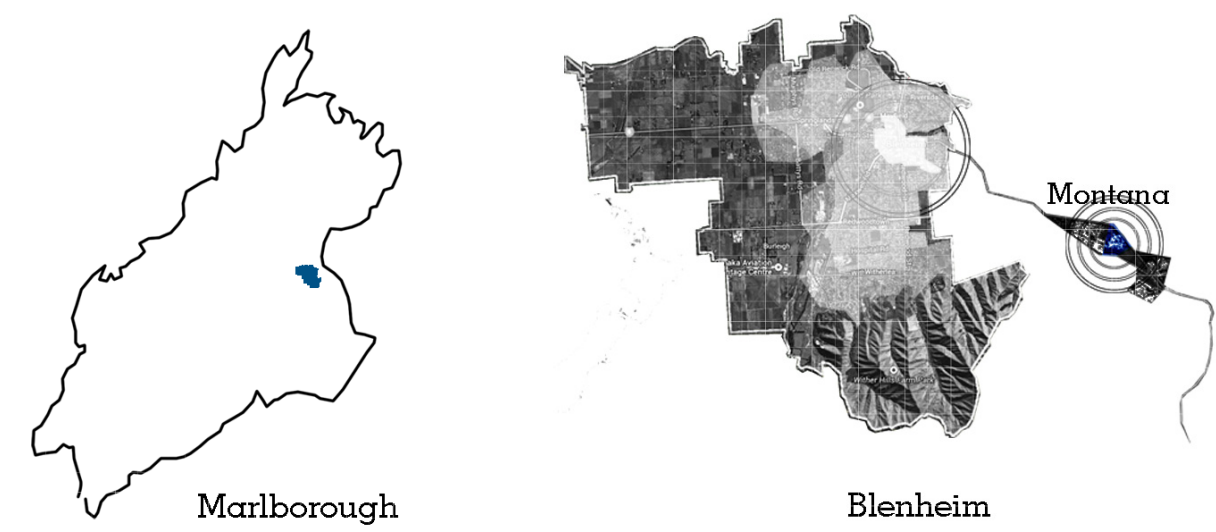

Blenheim

is flat with a small river running along the southern boundary. The site does not mostly flat however the large industrial area to the south provides a challenge to either exclude or soften. 
REGIONAL MAP

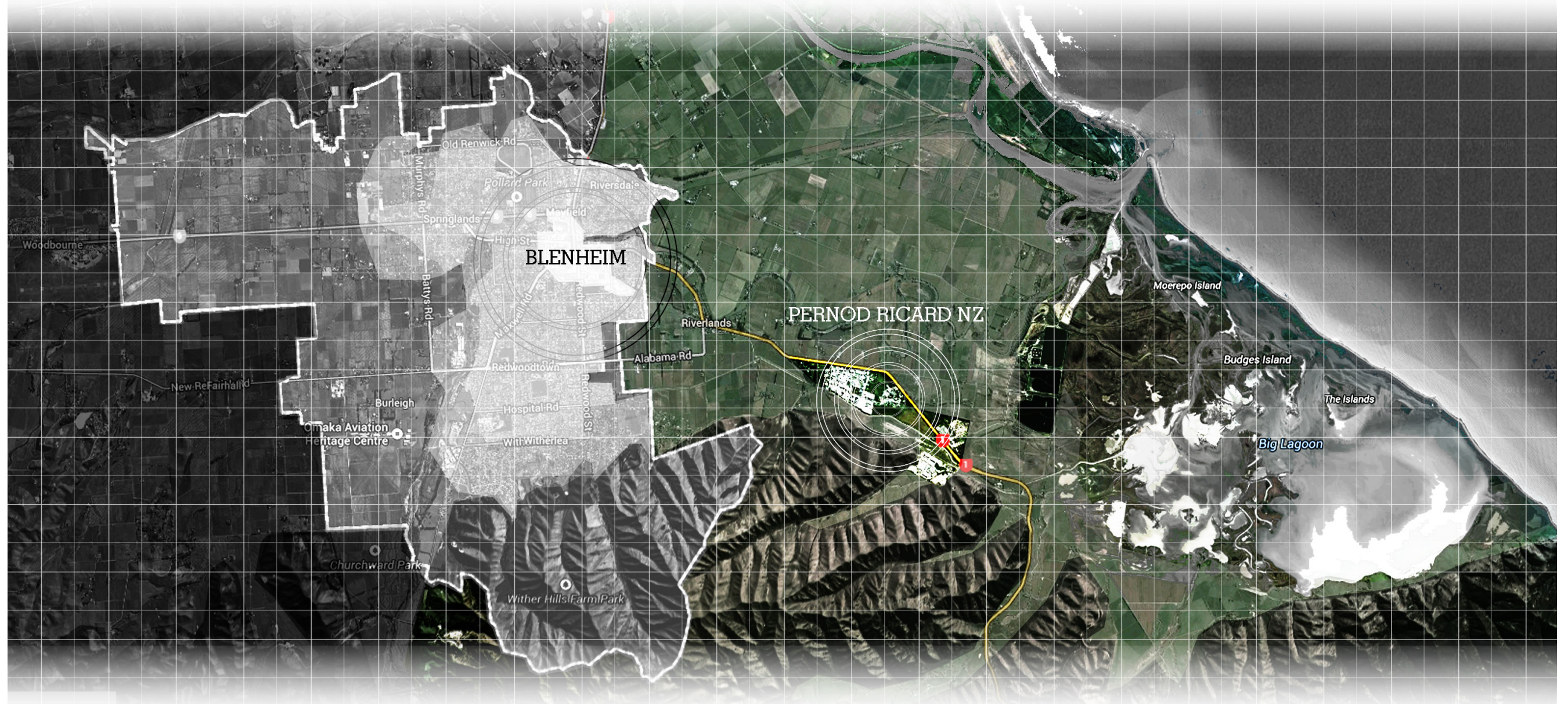

Fig 5.4 Regional Map + Pernod Ricard Winery 
SURROUNDING AREA MAP

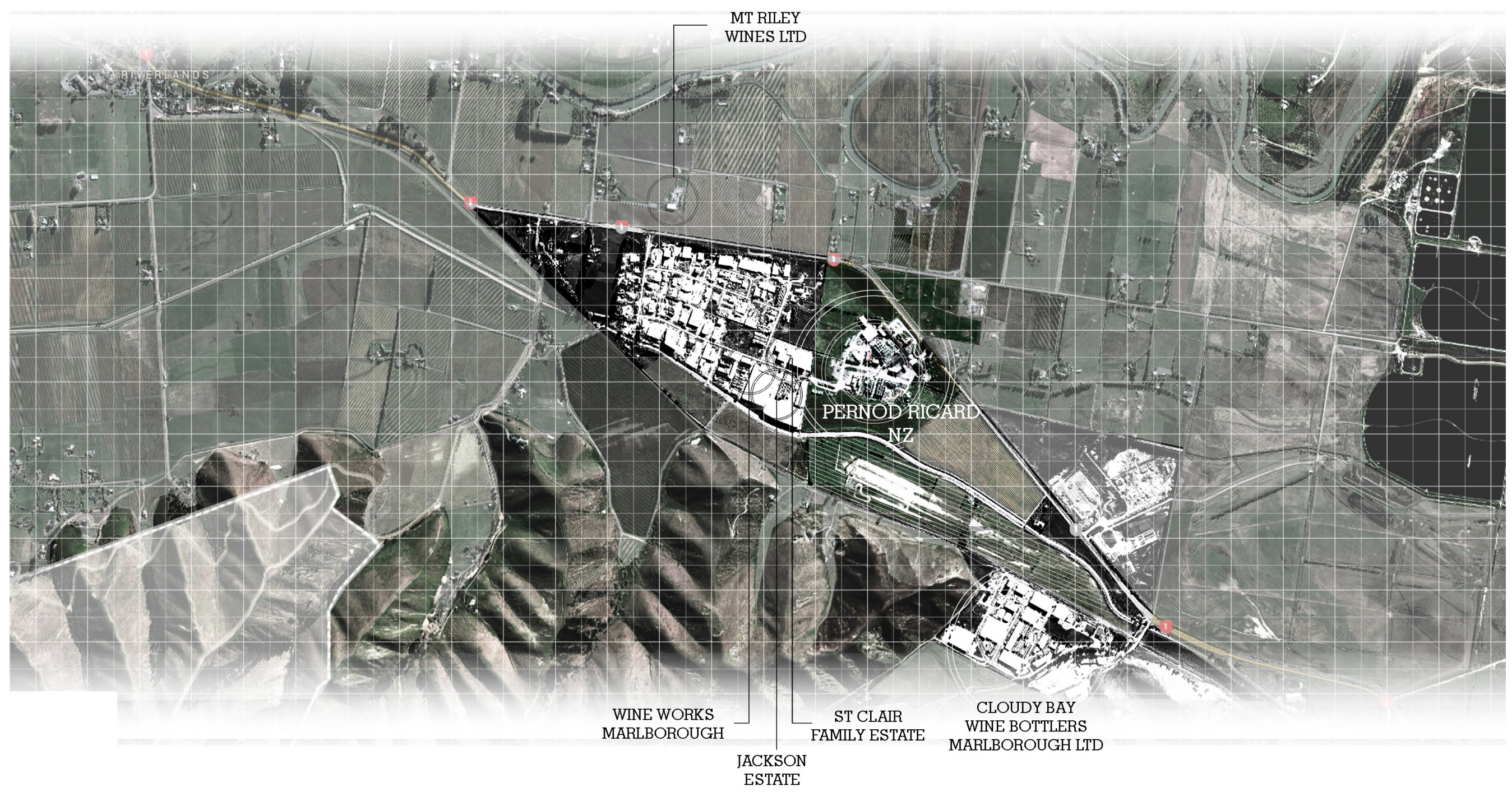

Fig 5.5 Surrounding Area of Pernod Ricard Winery 
SITE AXONOMETRIC

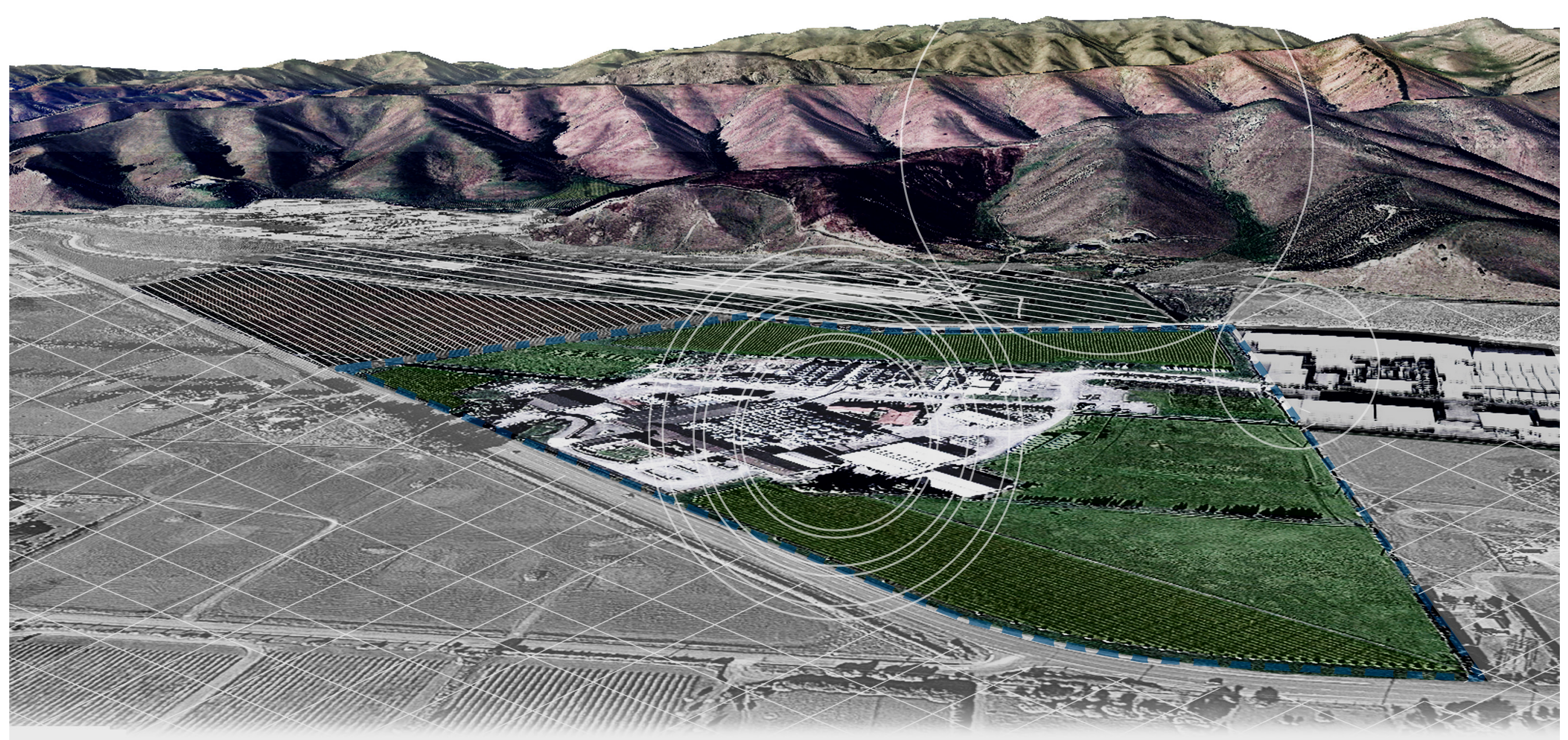

Fig 5.6 Site Axonometric of Pernod Ricard Winery 


\subsection{BOUNDARIES $(1,2)$}

To enhance the site experience the large buildings to the south west of the site must be hidden to preserve the vistas and improve the experience. This will require an architectural feature that is between 8-12 metres high.

The empty subdivision to the north west in future could inflict the same problem however it provides an excellent viewpoint towards the hills of the start of the Marlborough Sounds. By using the built form on the site the winery should look to frame this view while concealing the neighbouring site.

The space between the buildings on the boundary will be best utilised as a service driveway for trucks and work vehicles.

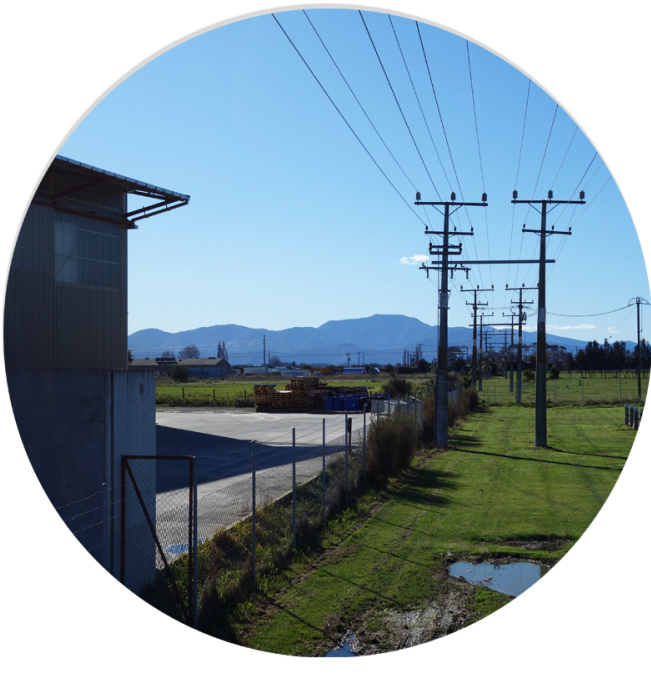

Fig 5.7 Boundary 1

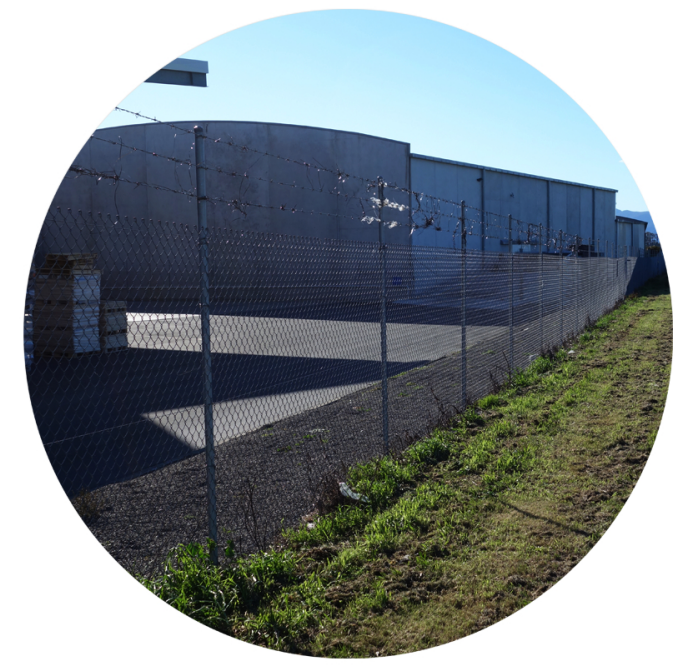

Fig 5.8 Boundary 2

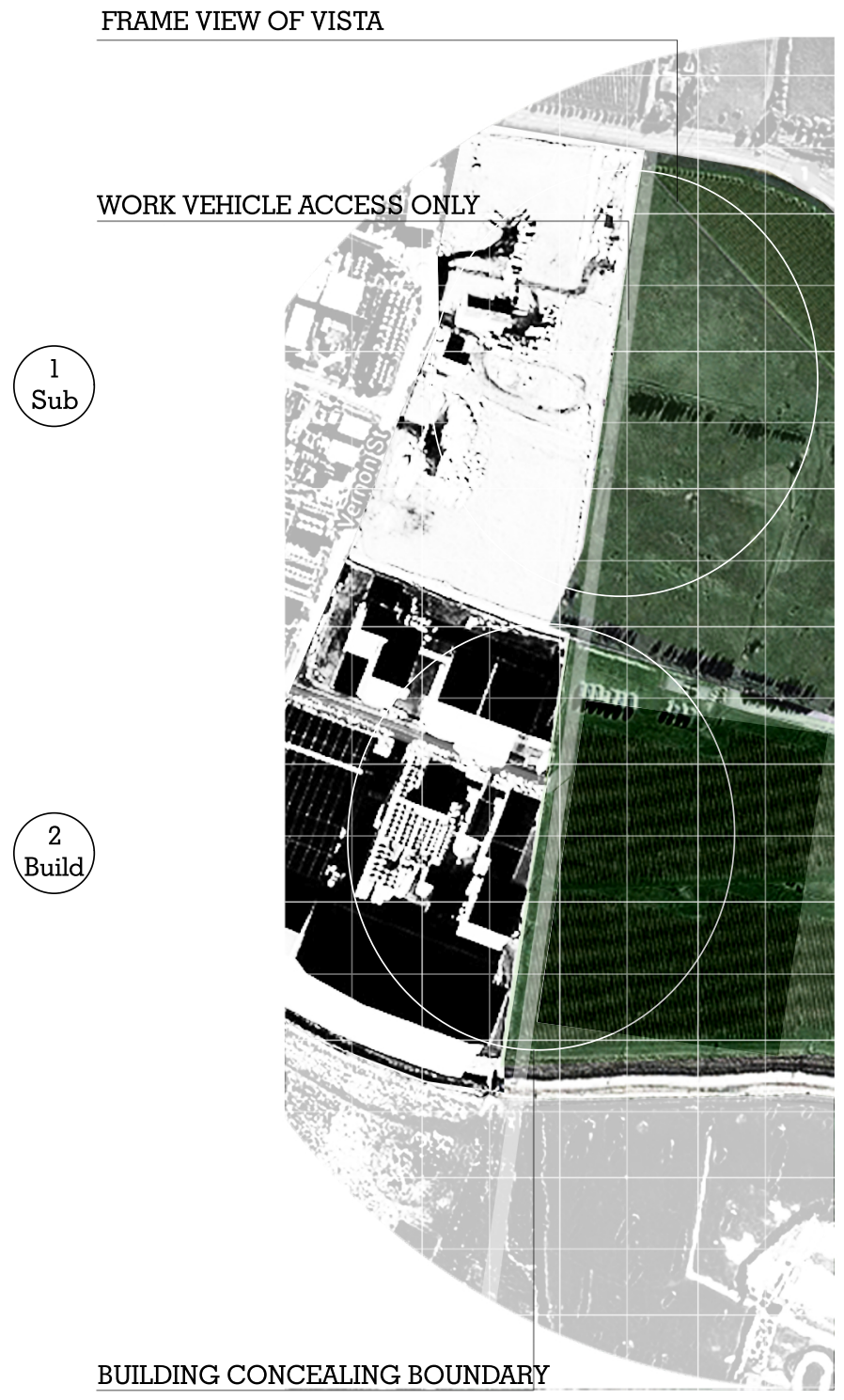

Fig 5.9 Boundary Diagram 



\subsection{VISTAS}

(1) The main vista to be seen from the cellar door or restaurant looks onto the stream and farmlands backdropped by the hills to the south. The railroad passes parallel to the hills where a train passes occasionally expressing the industry of the Marlborough region.

(1) Another viewpoint in this vista is further west looking to the cliffs that fall into the sea past blue lagoon. In the distance an industrial building from Wineworks Marlborough stands out against the surrounding hills.

(2) This viewpoint is designed for the approach. The view is framed by one of the buildings in the industrial area and contrasts the bushy green characteristic of the Marlborough

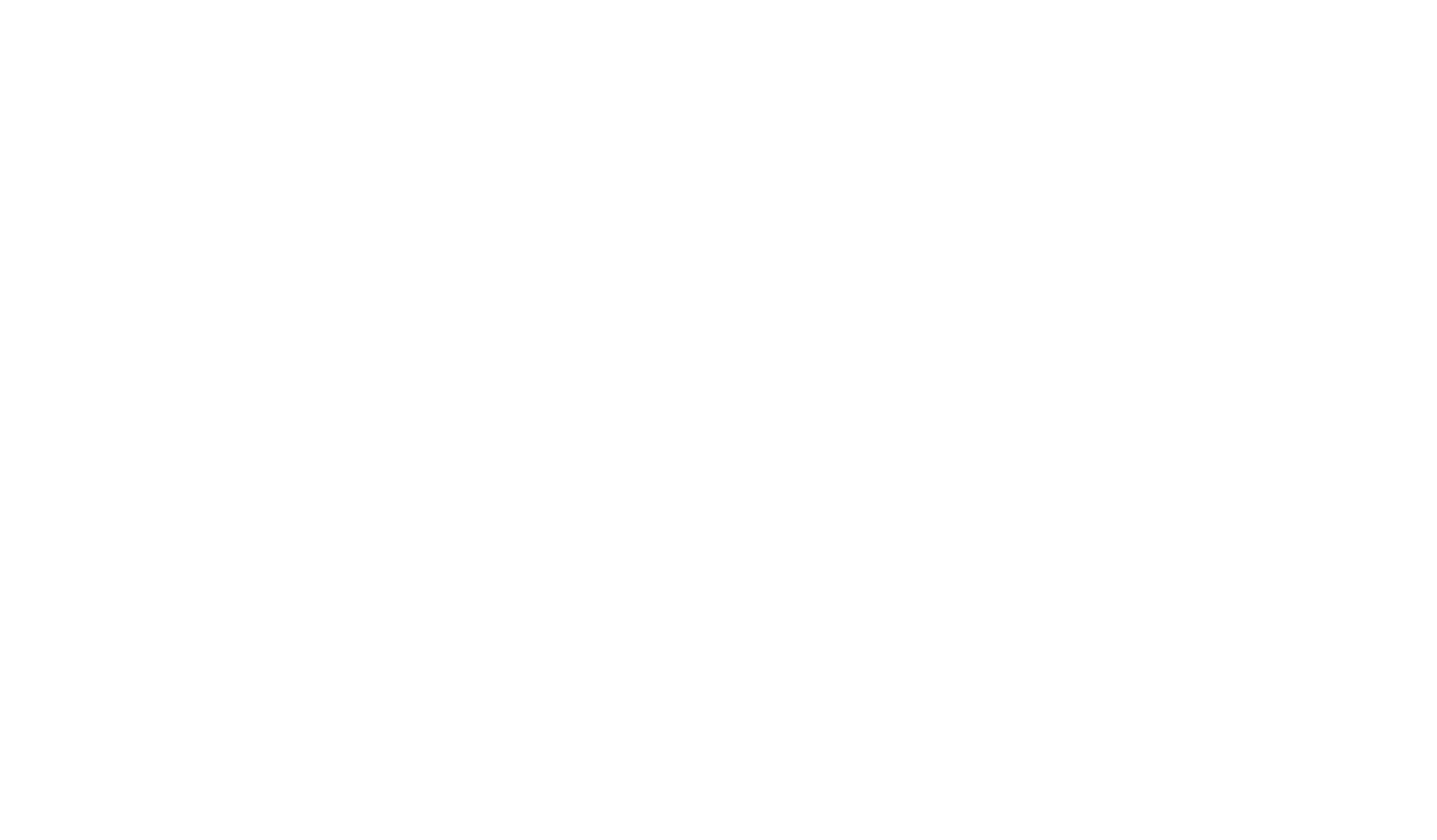

Fig 5.13 Vista Diagram

Sounds with the bareness of Blenheim's surrounding hills. 


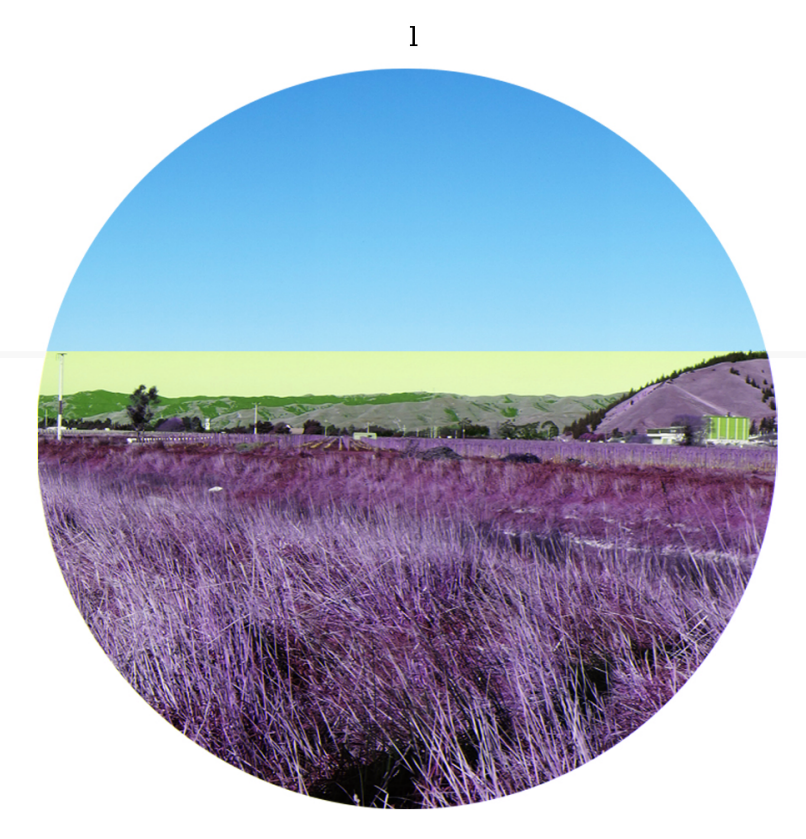

Fig 5.14 Vista

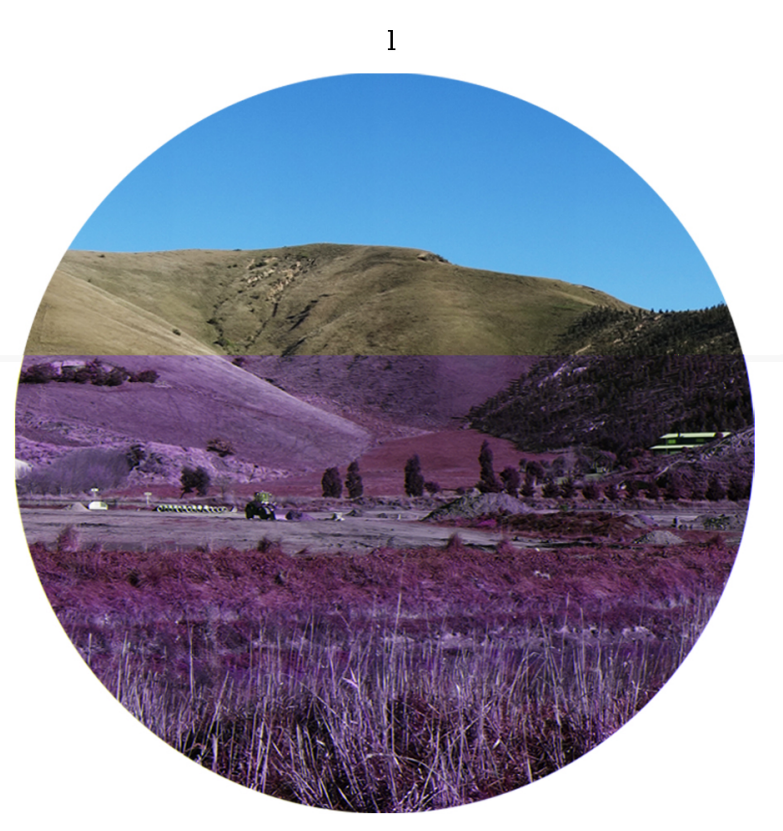

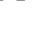

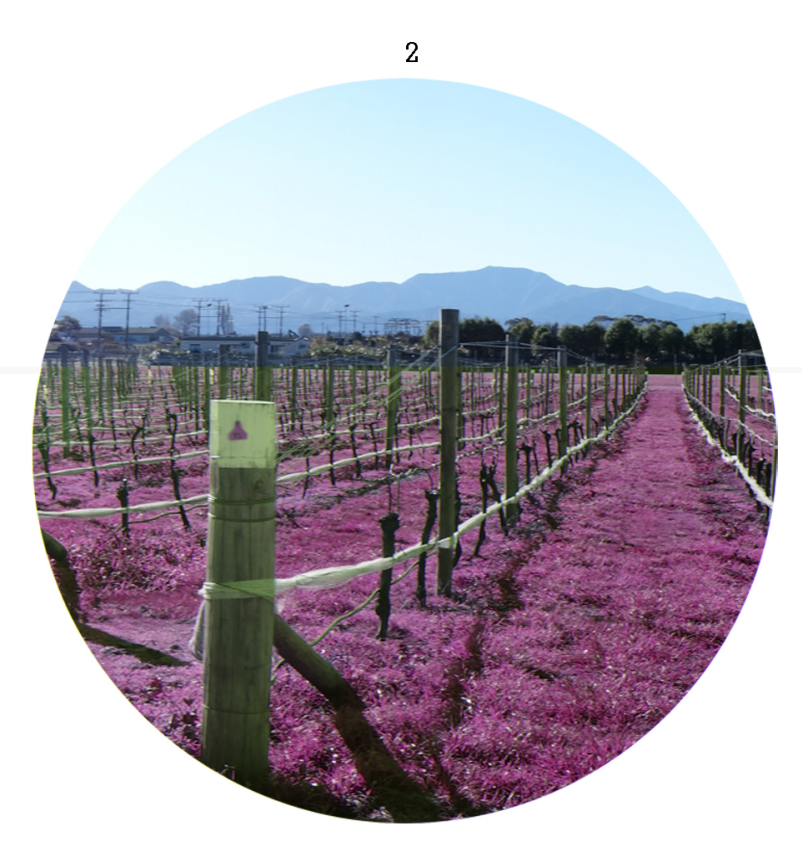

Fig 5.15 Vista 2 


\subsection{APPROACH AND ENTRY}

To ensure a quality experience is realised analysis of four wineries was undertaken. The approach and entry to a winery are subtle but important aspects involved with the design of a winery. The approach and entry is "where first impressions are formed and customer expectations are developed" (Carlsen 2011, p. 284). Generally speaking there is a physical statement that suggests a sense of arrival. This can be as simple as a sign or as extravagant as an archway or sculpture.

Landscaping of the driveway by use of trees or other elements can suggest an axial directionality and understanding that leads one to the winery. "The long winding treelined driveway gave the impression that the estate was well planned and designed" (Carlsen 2011, p. 279). Often in wineries the use of vines growing perpendicularly to
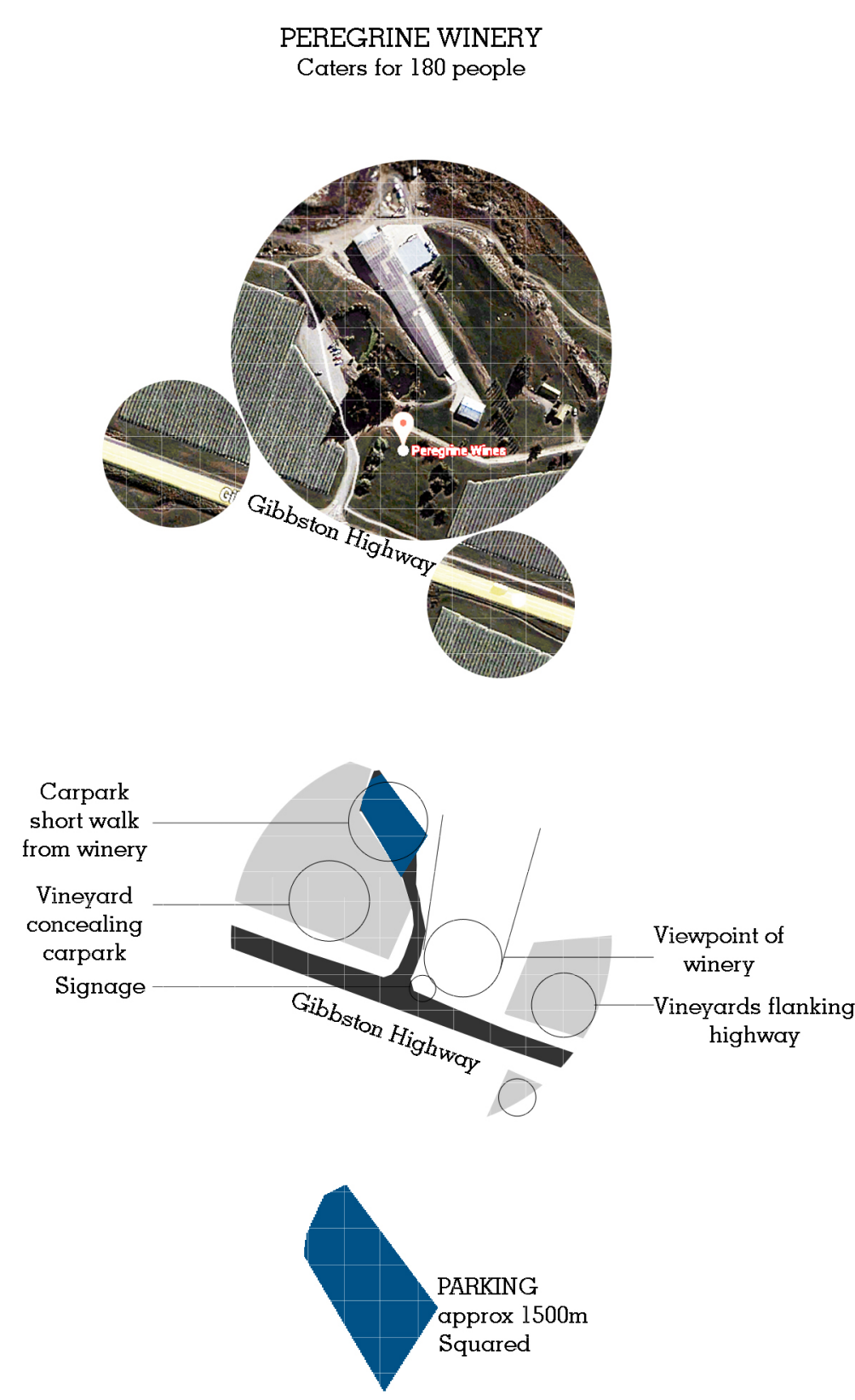

Fig 5.16 Peregrine Approach Anclysis
CRAGGY RANGE

Caters for 120 people

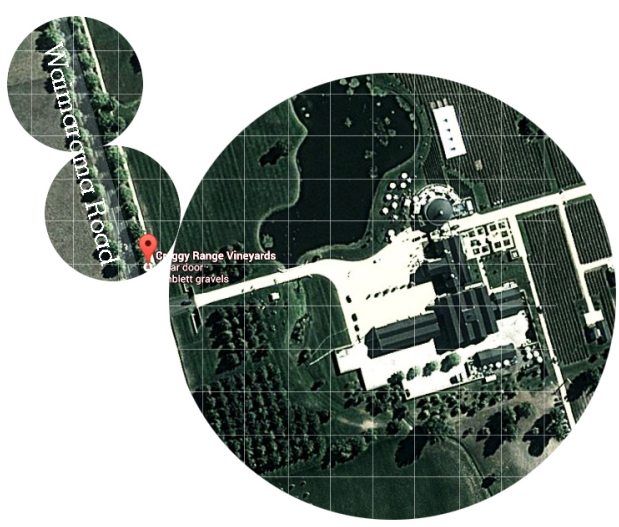

Planted

Trees Vineyard Lake

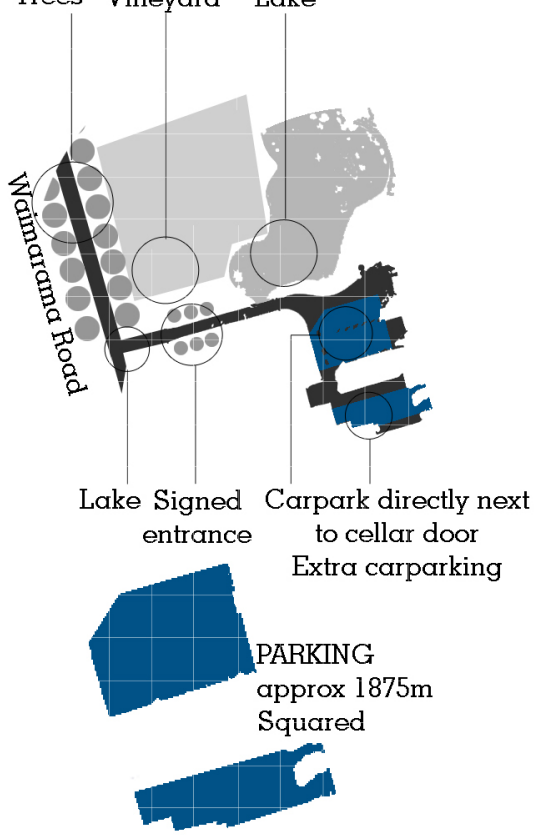

Fig 5.17 Craggy Range Approach Analysis 

PERNOD RICARD WINERY

Caters for 160 people

PARKING $2500 \mathrm{~m}$ Squared

- TREE/BUSHES

— SEALED DRIVEWAY

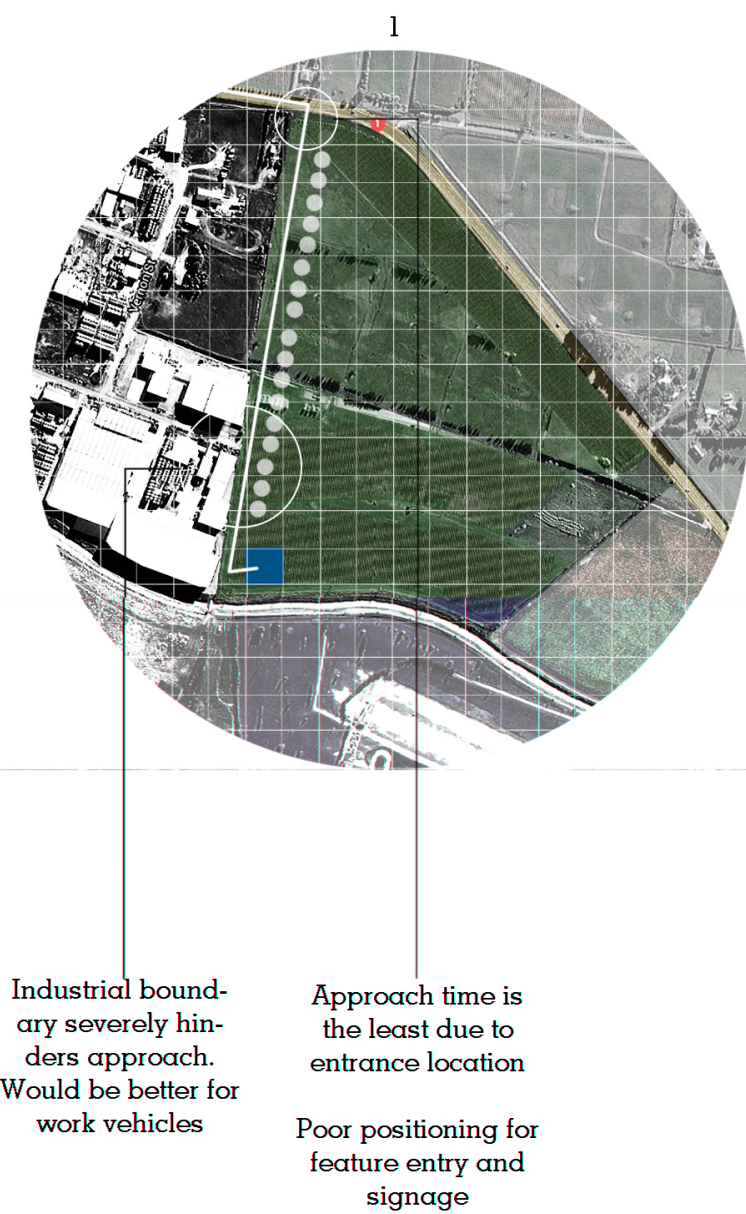
signage

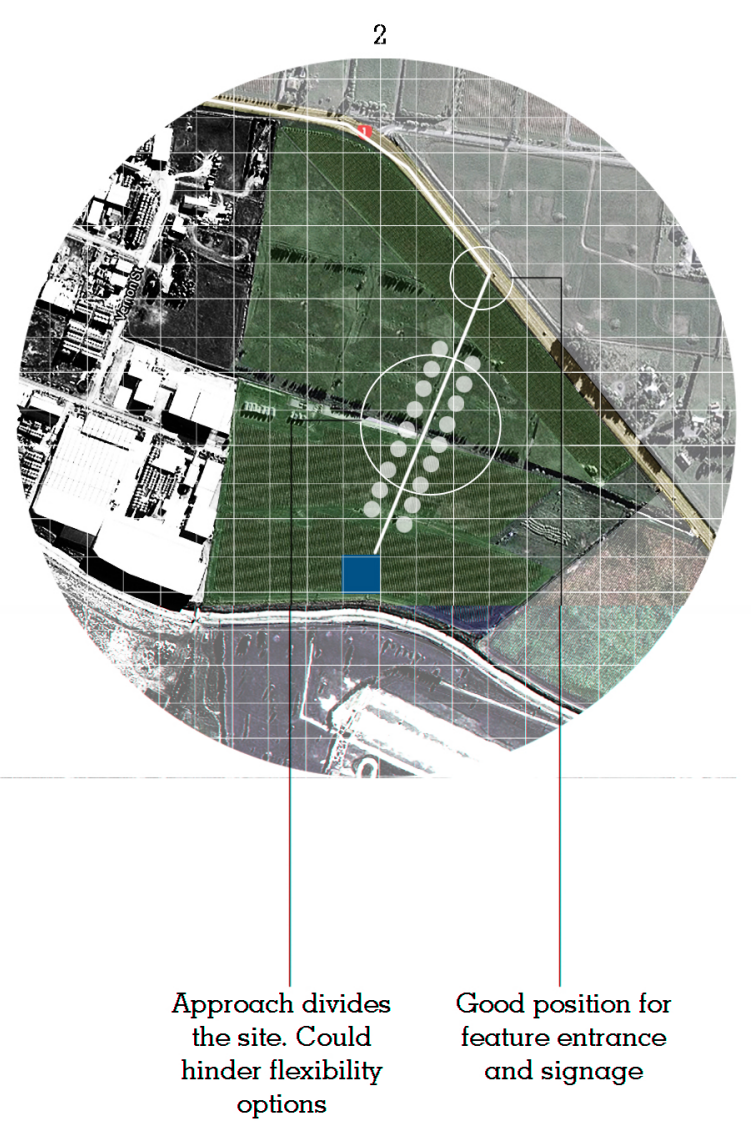

Strong possiblity

for planting of trees

to add to approach

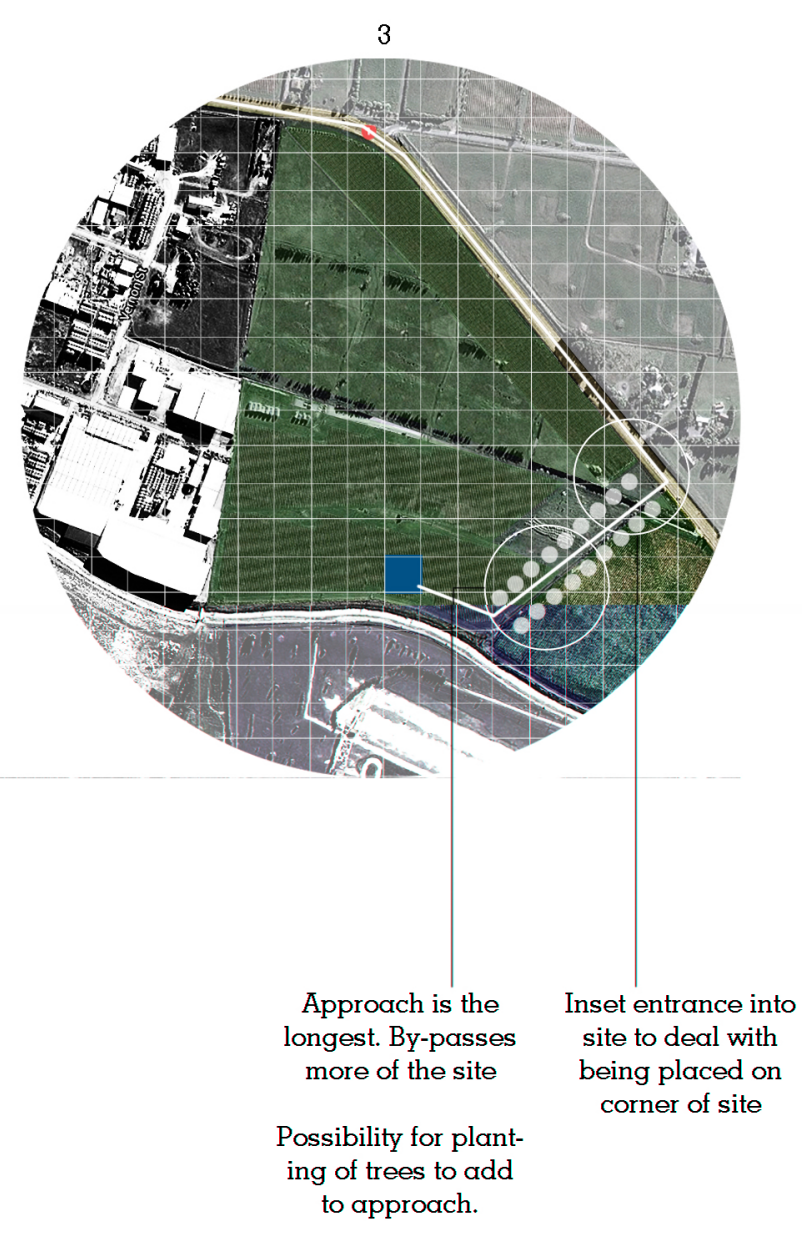

Purchase of neighbouring vineyard? 
SEGMENTED LAYOUT

$3 \times 20$ car parks

90 DEGREE LAYOUT

64 car parks

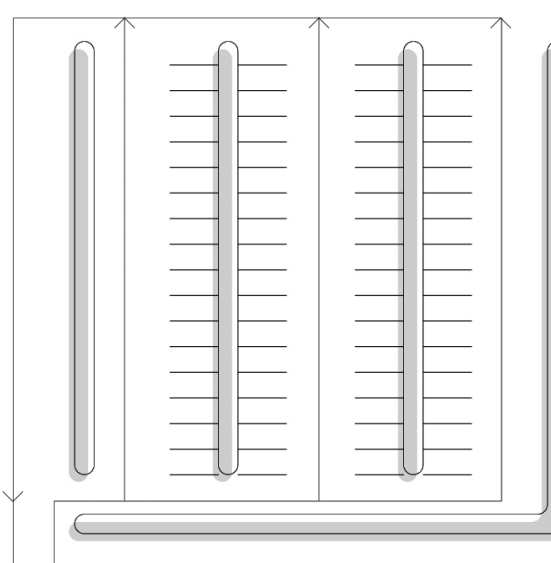

$1: 1000$ $50 \mathrm{~m} \times 50 \mathrm{~m}$

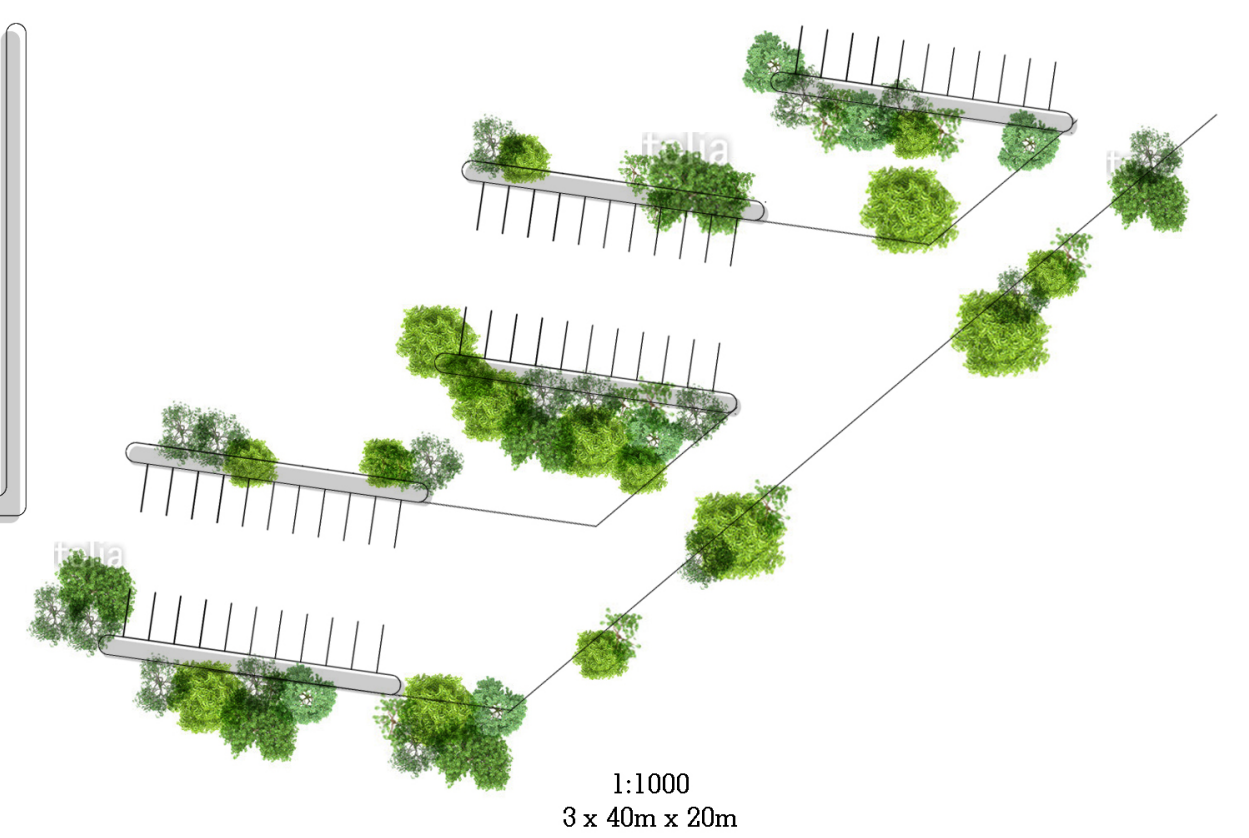

\subsection{CAR PARK LAYOUT}

The car park must be arranged so that it has sufficient spaces for a wedding of 150 people plus the 20 - 30 people that are working. The car per person ratio for a wedding is about 1:3 people therefore a suitable number of carparks for an event this size would be approximately 60.

To avoid the feeling of driving into the country side to find a massive carpark by segmenting the carparks into smaller areas would improve the experience. 


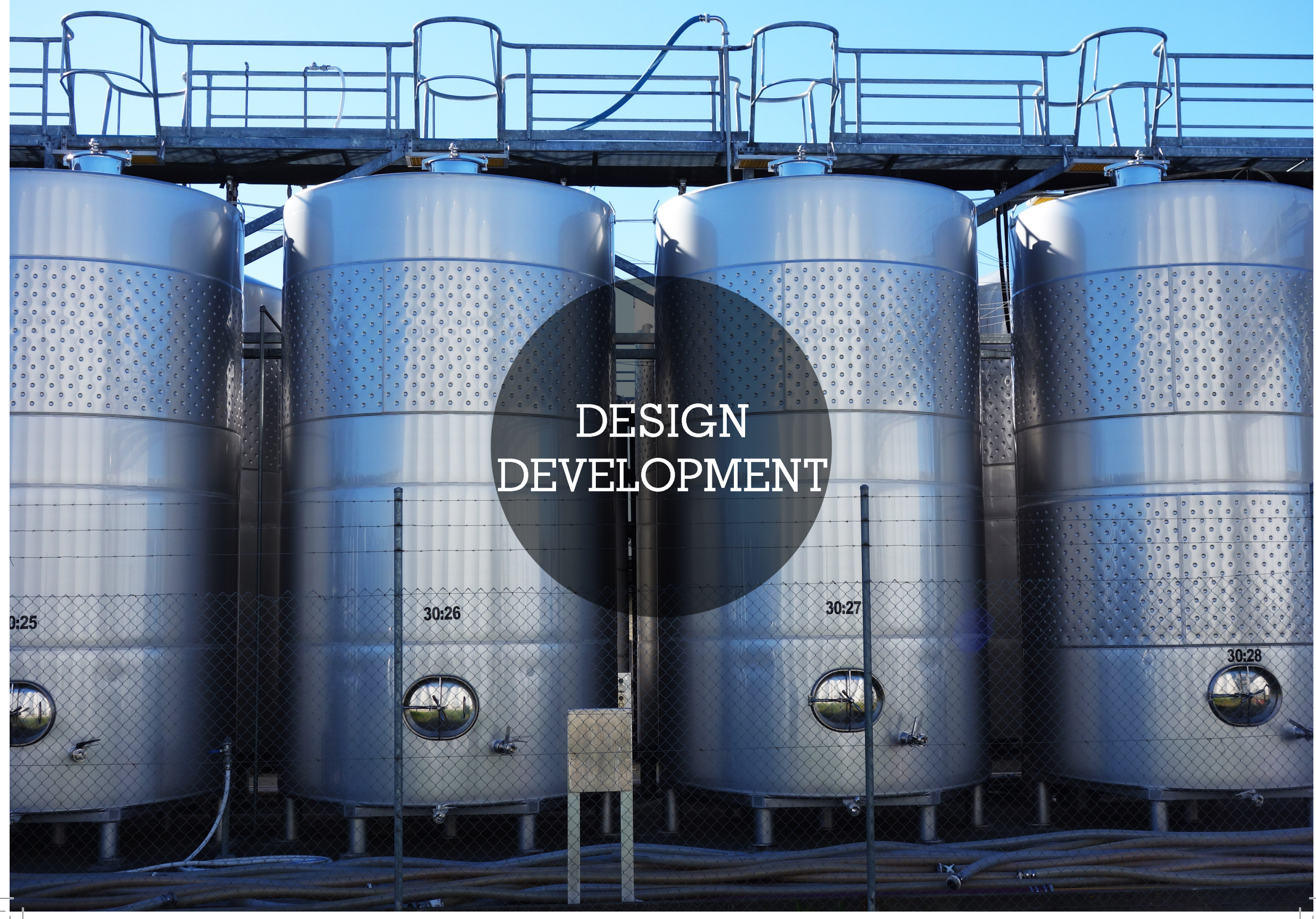




\subsection{DESIGN DEVELOPMENT}

The section timelines the design process undertaken, early planning and massing studies and diagrams the masterplan of the design. 


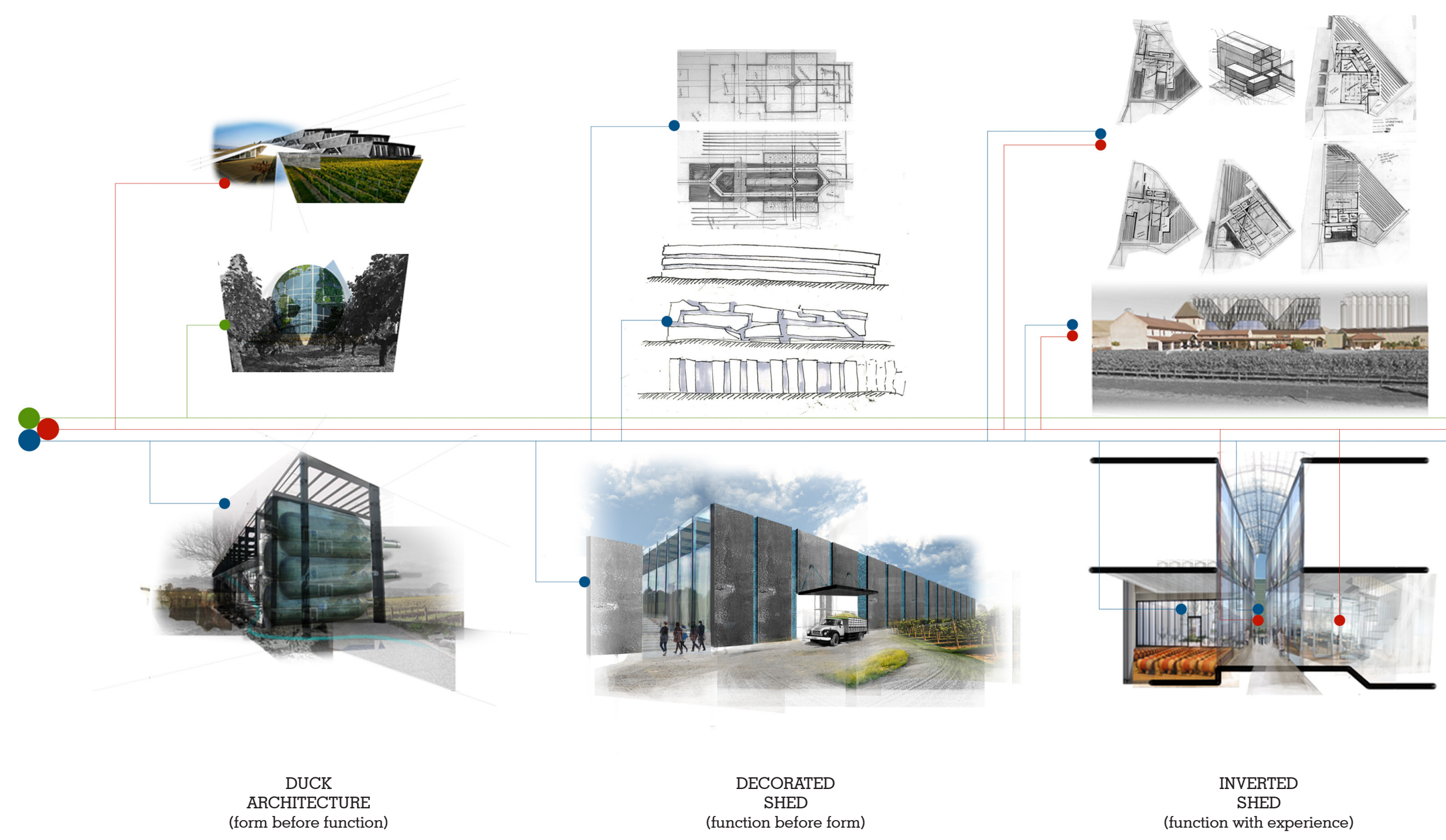

Fig 6.1 Development Timeline 



\subsection{EXPERIENCE STRATEGY}

Worked investigations into the duck, decorated, and inverted sheds revealed a failure to comply with all parts of Pernod Ricards corporate identity particularly due to the scale of operation of the wine production and the way it affected the landscape.

\section{Further design strategies investigated the use of buildings as landscape} features. Initially this affected the functionality and therefore the product. This lead to beginning with the winemaking process and attempting to bring together building and landscape which resulted in a less effective experience.

Finally by applying a corporate value to each building and beginning the planning with the product buildings layout the values could be communicated effectively and clearly without affecting the process. 


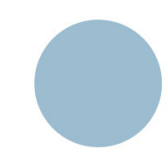

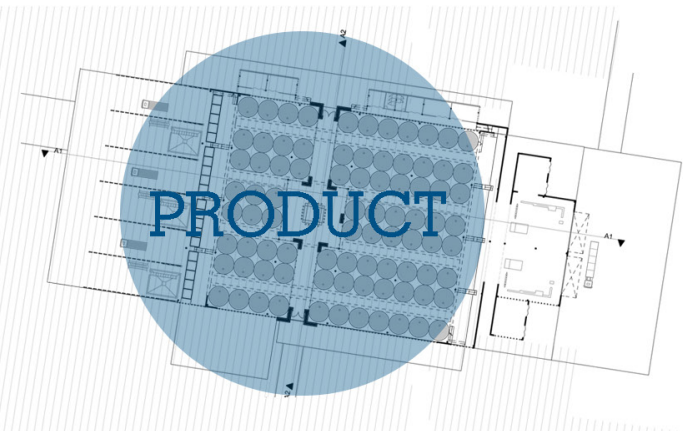
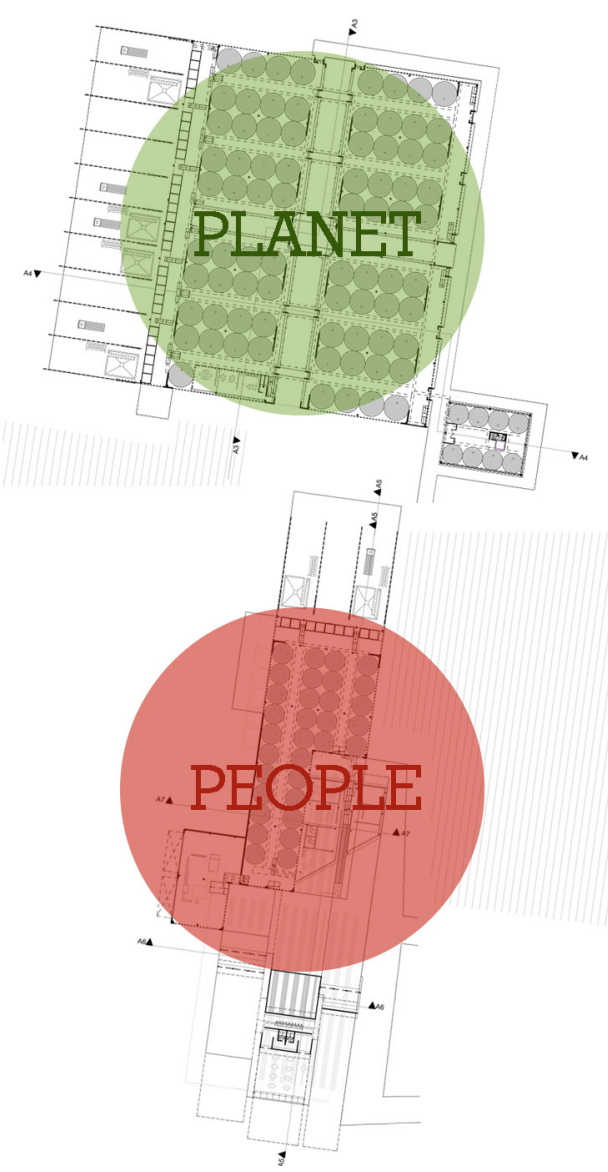
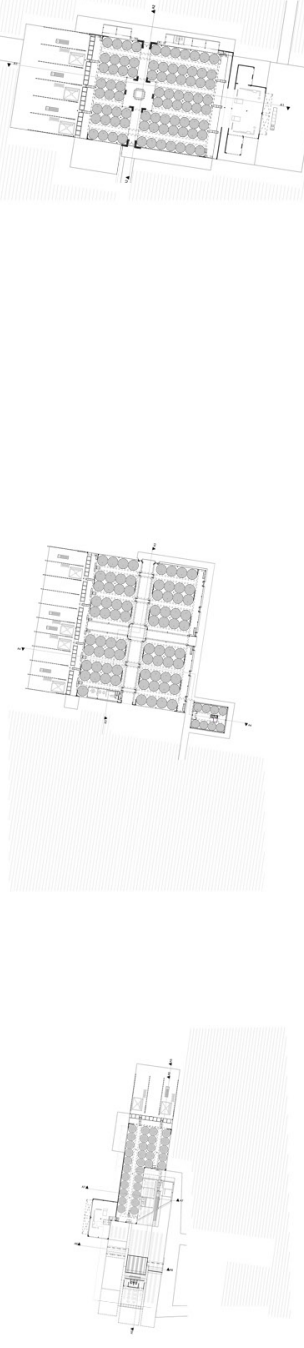

Fig 6.3 Experience Strategy Diagram 


\subsection{GRID STUDIES}

Similar to Consenza with the Olivetti factory by using a series of drawings it is possible to cater for many elements such as vistas, troublesome boundaries and circulation, etc.

The following grid studies take into account these elements and are manipulated until a layout reveals itself that is suitable for the site.
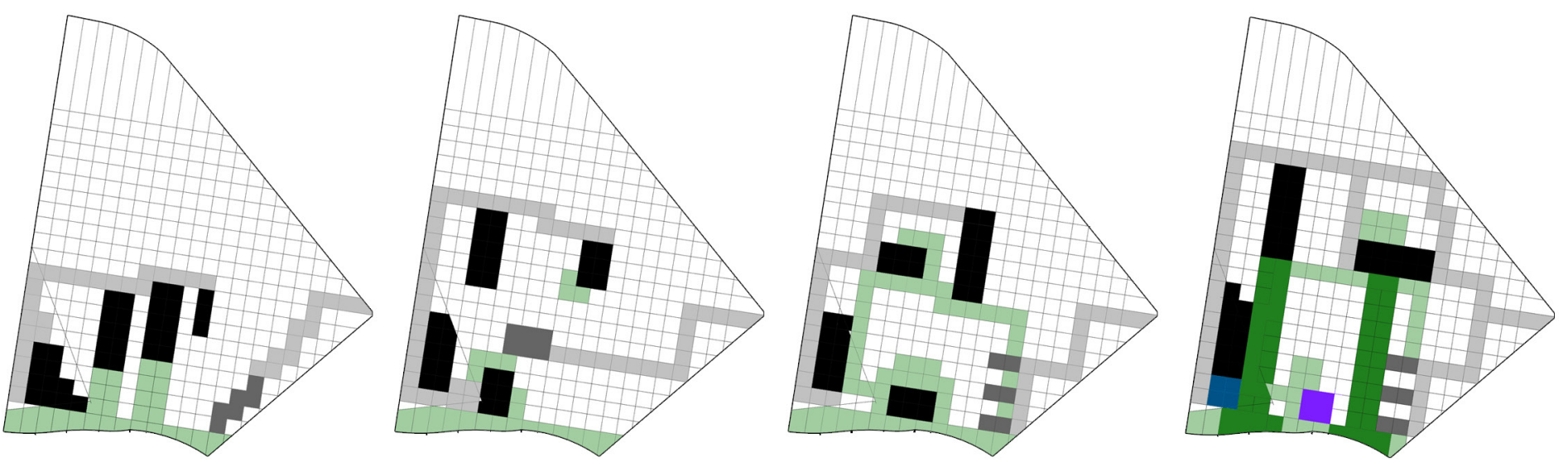

Production Buildings

Walkways/Outdoor Spaces

Carparking

Driveways
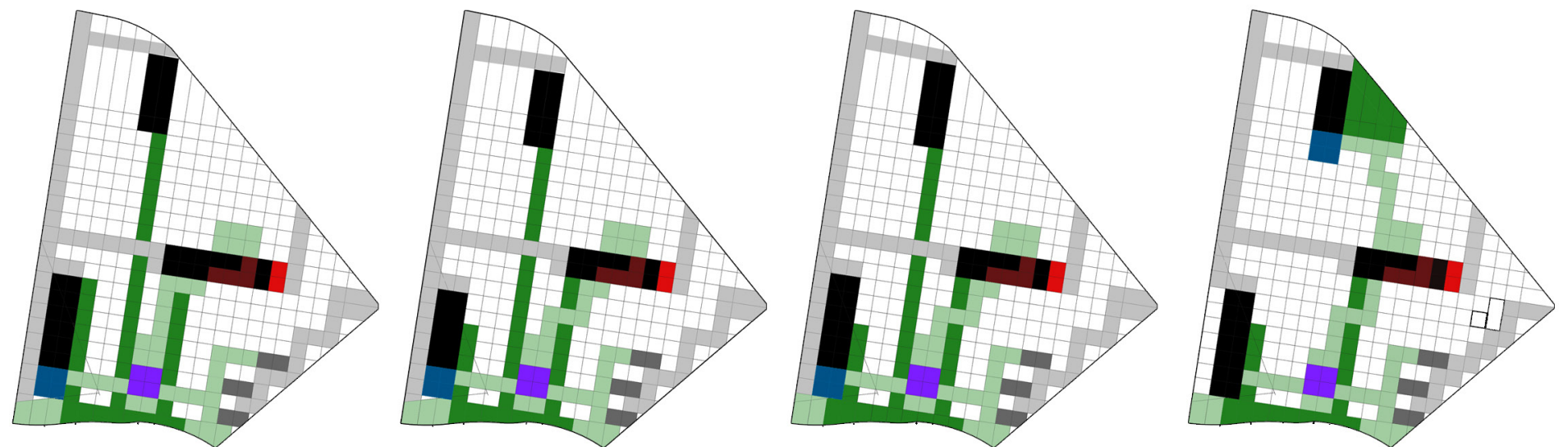

Fig 6.4 Grid Study Diagram 

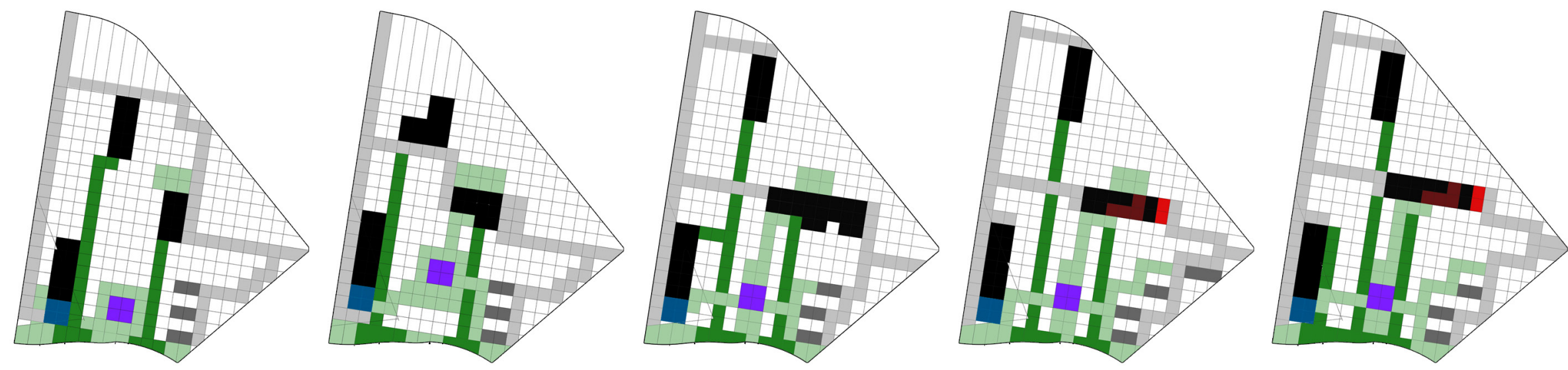

Wetlands

Restaurant/Function Room

Tower Tasting Room

Process Experience/Tasting Room

Bottling
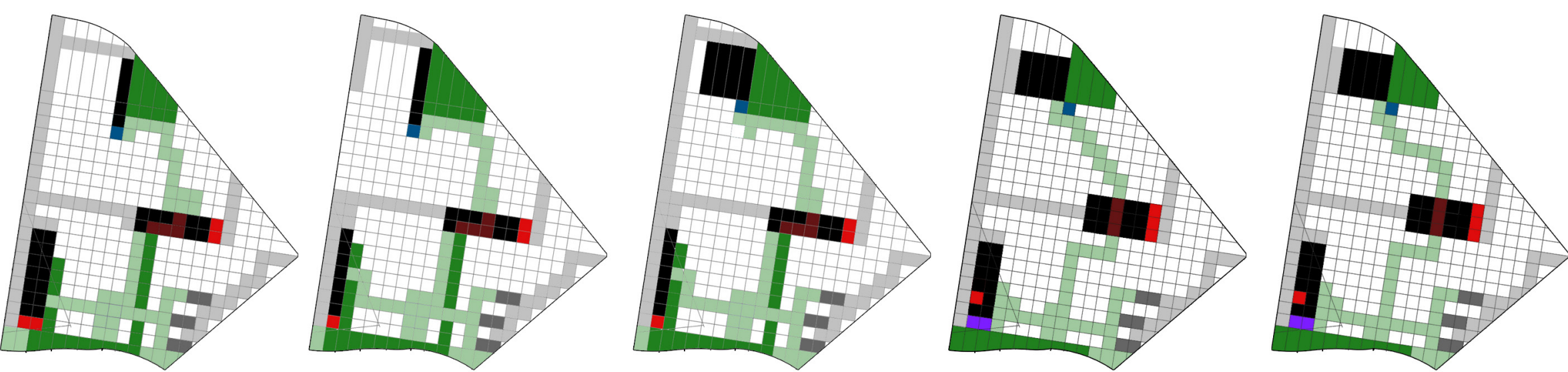

Fig 6.5 Grid Study Diagram 


\subsection{MASSING STUDIES}

With the addition of a tower the height of the surrounding buildings are critical to the image of the tower. The height of the production buildings are drawn from the selection of fermentation tanks as these are the highest piece of equipment involved in the production.

\section{In most cases the tanks are kept below ground} by five metres not only to make the transition

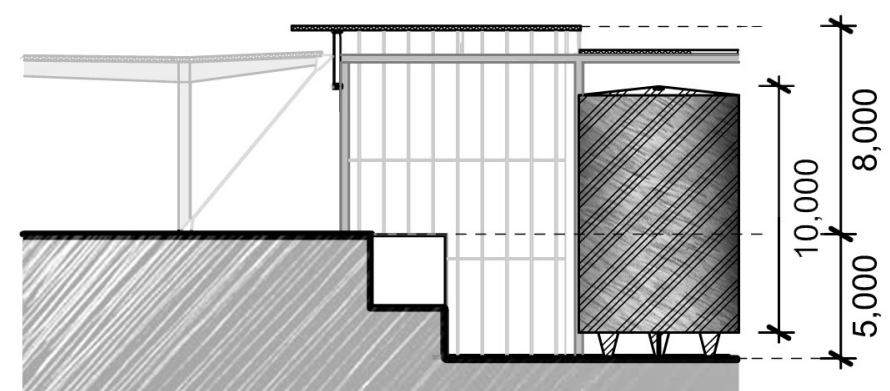

between fruit handling to open fermentation

to closed fermentation easier but also for the thermal properties that the earth has which will keep the closed fermentation tanks cool.
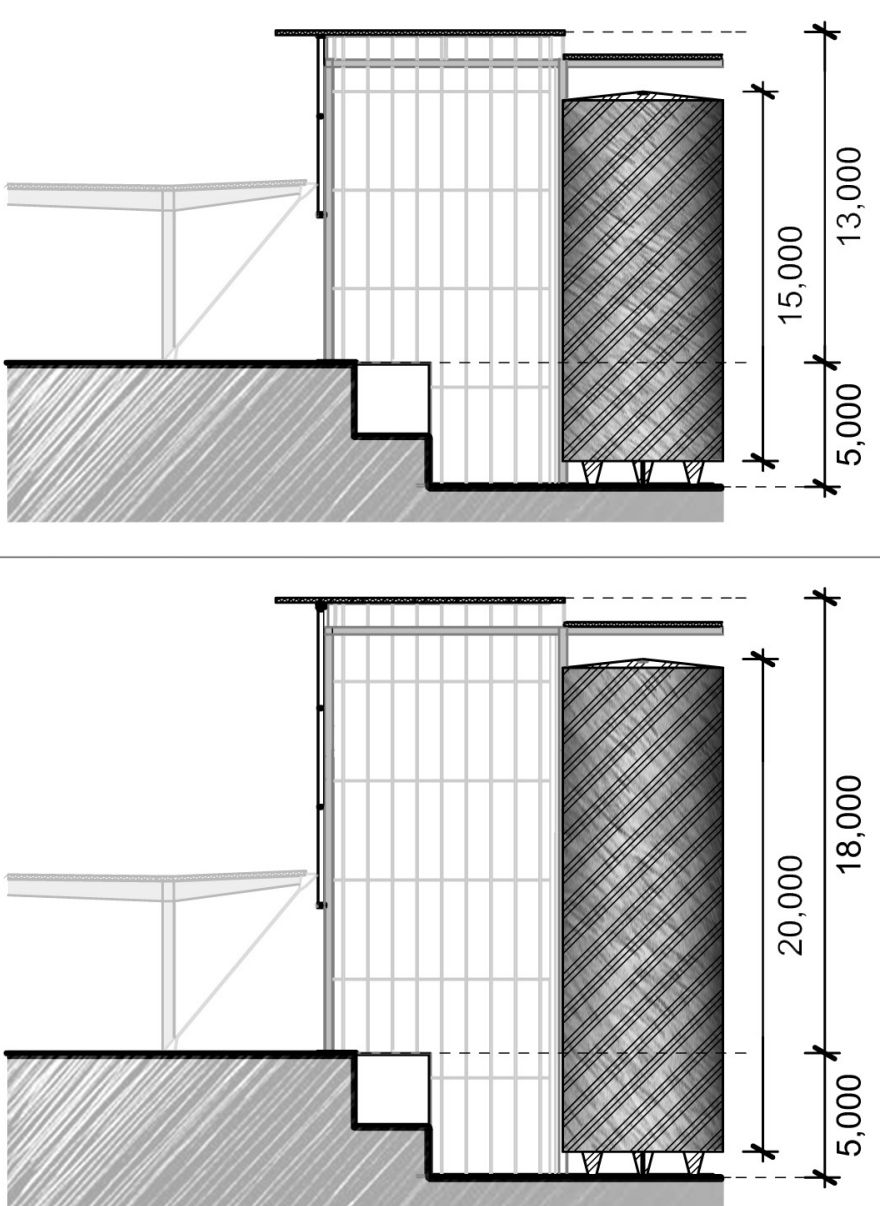

Fig 6.6 Massing Study Diagrom 

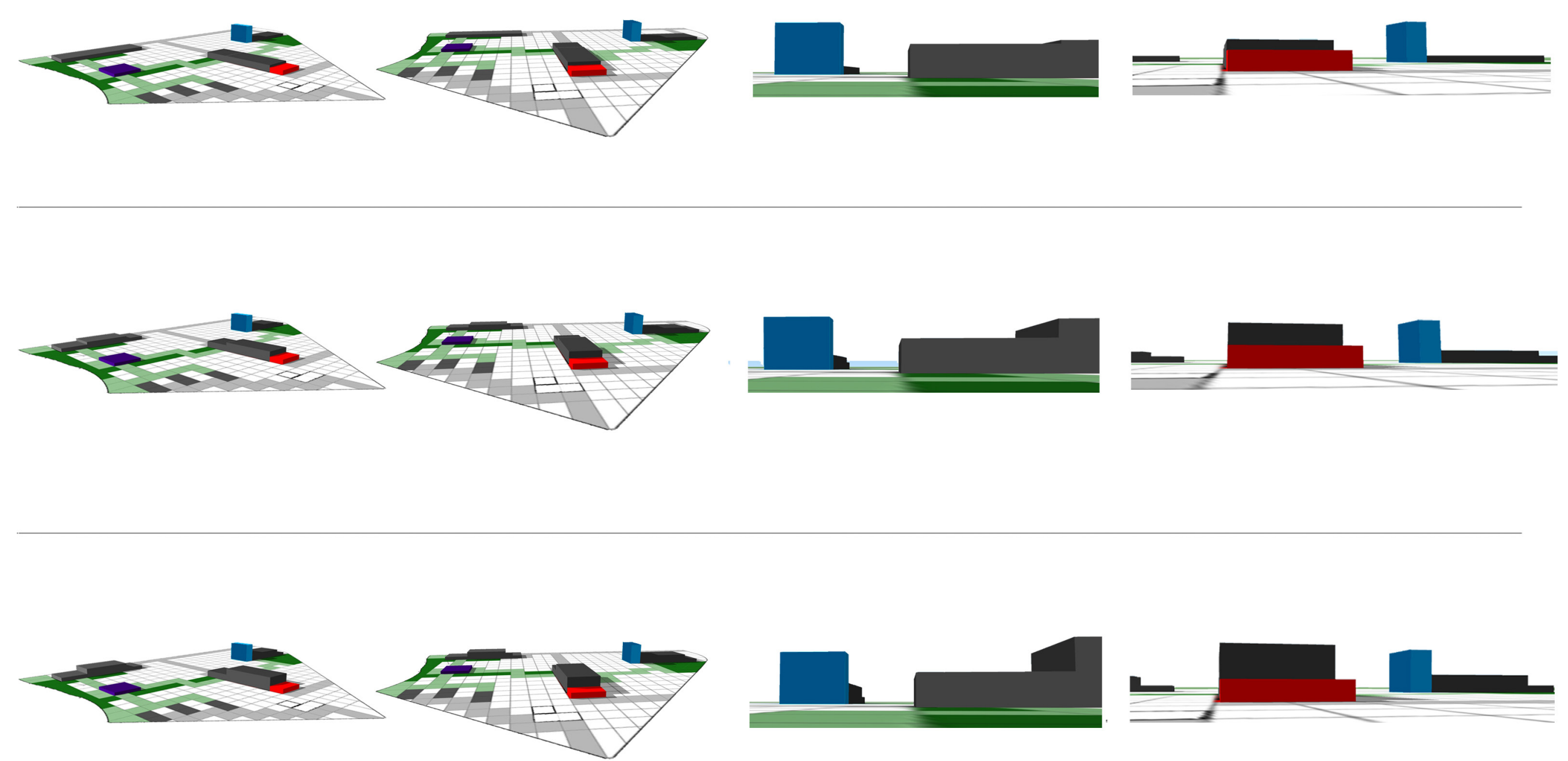
6.5 SITE PLAN

1. Entrance

2. Signage

3. Split carparking

4. Neighbouring vineyard

d Ricard symbol

7. Vineyards

8. Product experience winery

9. Wolkway to planet experience

10 . Planet experience winery

1 . Wetlands

2. Solar panel field

3. Park for visitors

River boundary

5. People experience winery

17. Neighbouring buildings

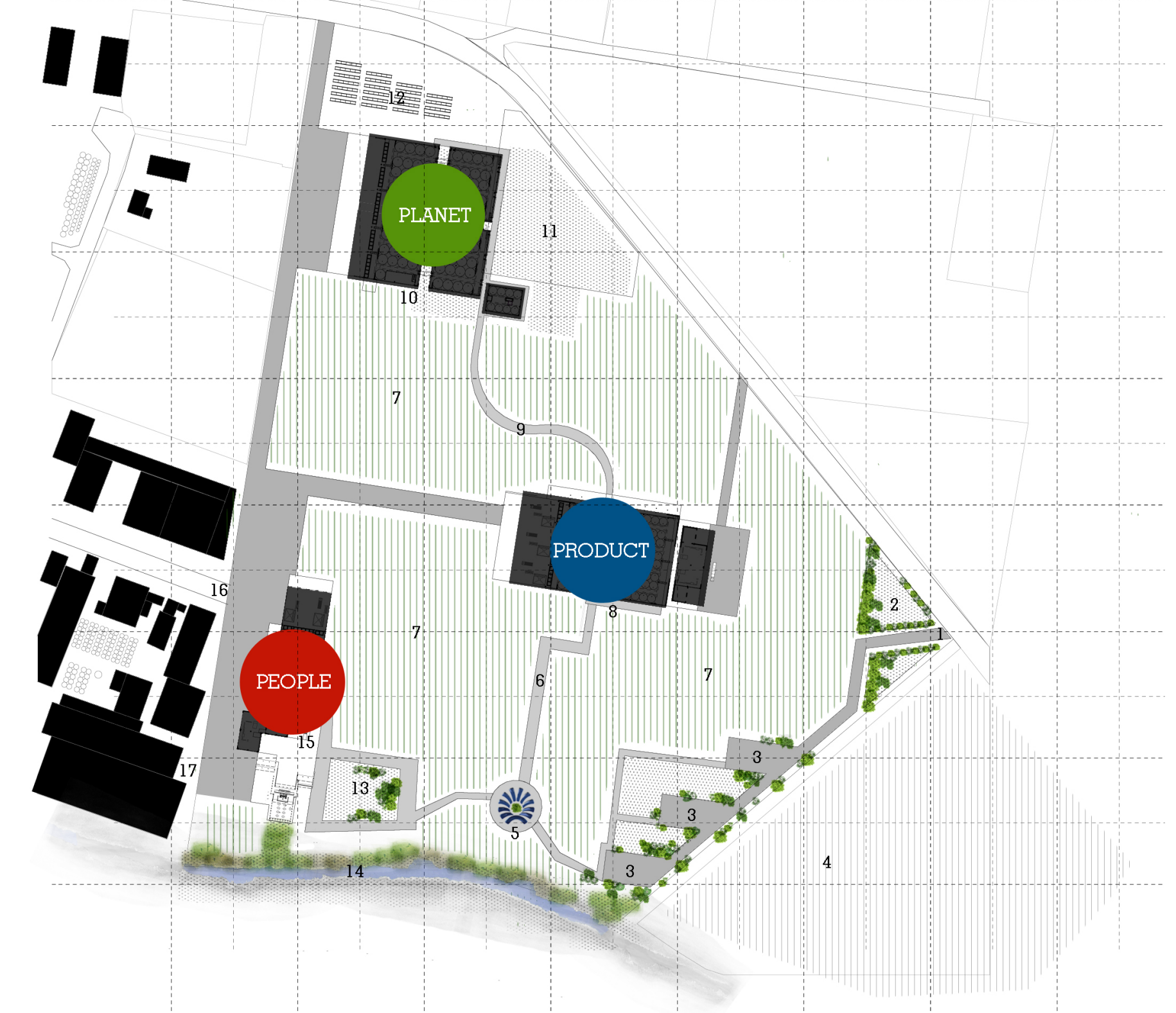




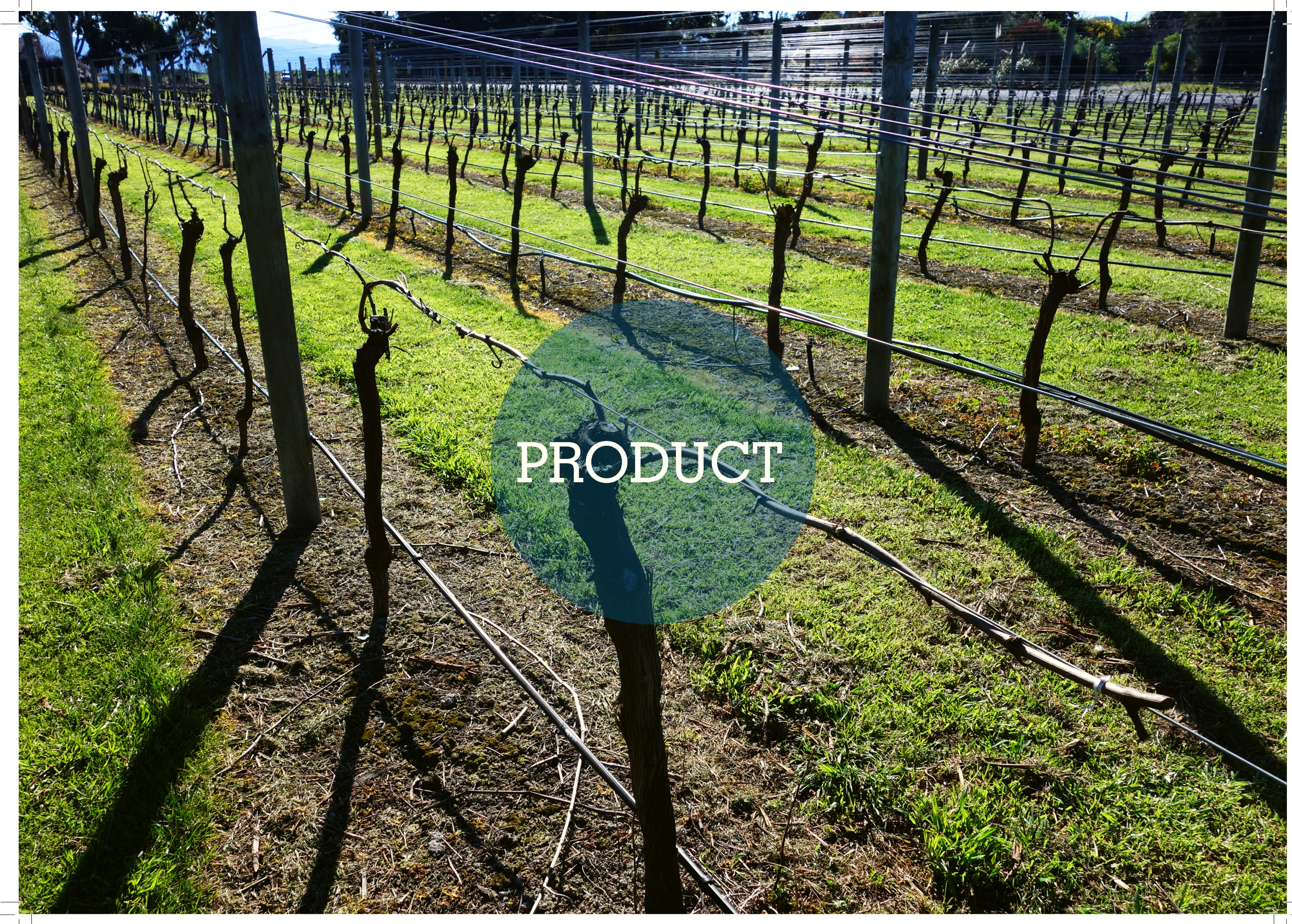




\subsection{COPORATE VALUE ONE - Product}

The section showcases key features of the product experience using images and diagrams to explain how the product corporate value is communicated. 


\subsection{WINEMAKING PROCESS}

To ensure quality of product the winemaking process must be as efficient and streamlined as possible. The winemaking process has five main steps:

1. Raw Fruit Handling

2. Fermentation

3. Maturation

4. $\quad$ Finishing

5. Warehouse \& Dispatch

Oaked Wines

Un-oaked Wines

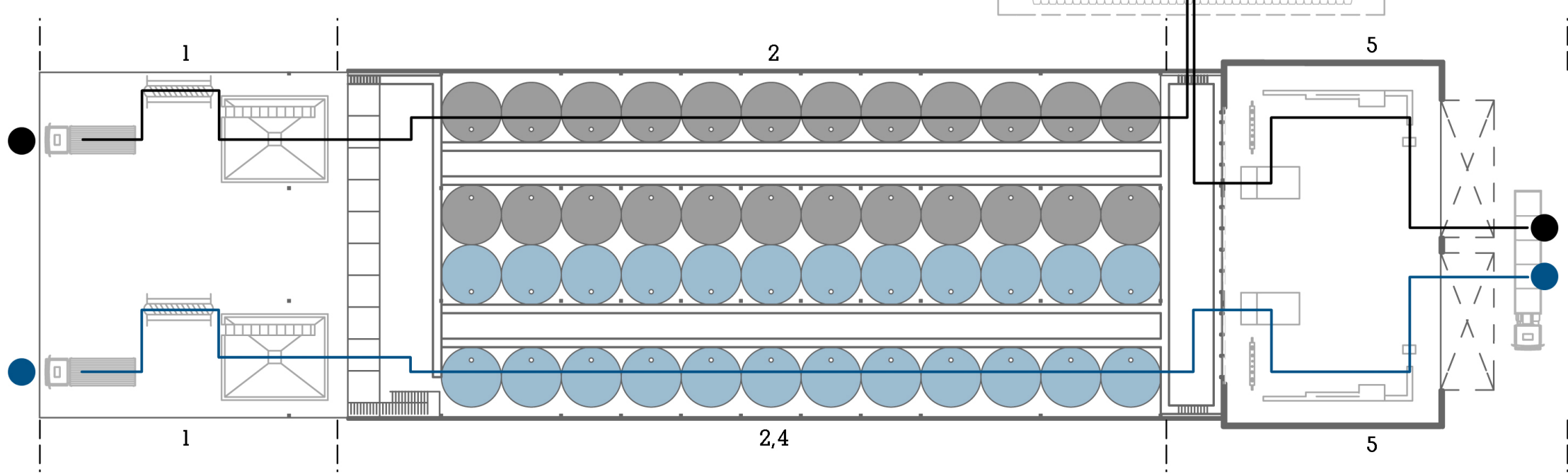

Fig 7.1 Winemaking Process Diagram

Because the building is focussed on ensuring efficiency of process and quality of product this building should adopt a 'decorated shed' like strategy where the process takes priority over the form. The incorporation of an architectural experience should be second to the process and if possible work together. Because Pernod Ricard's Sauvignon Blanc is their most well known and most exported wine the 'Product' production facility produces $100 \%$

Sauvignon Blanc which means that an oaking room is not required. 


\subsection{WINEMAKING EXPERIENCE}

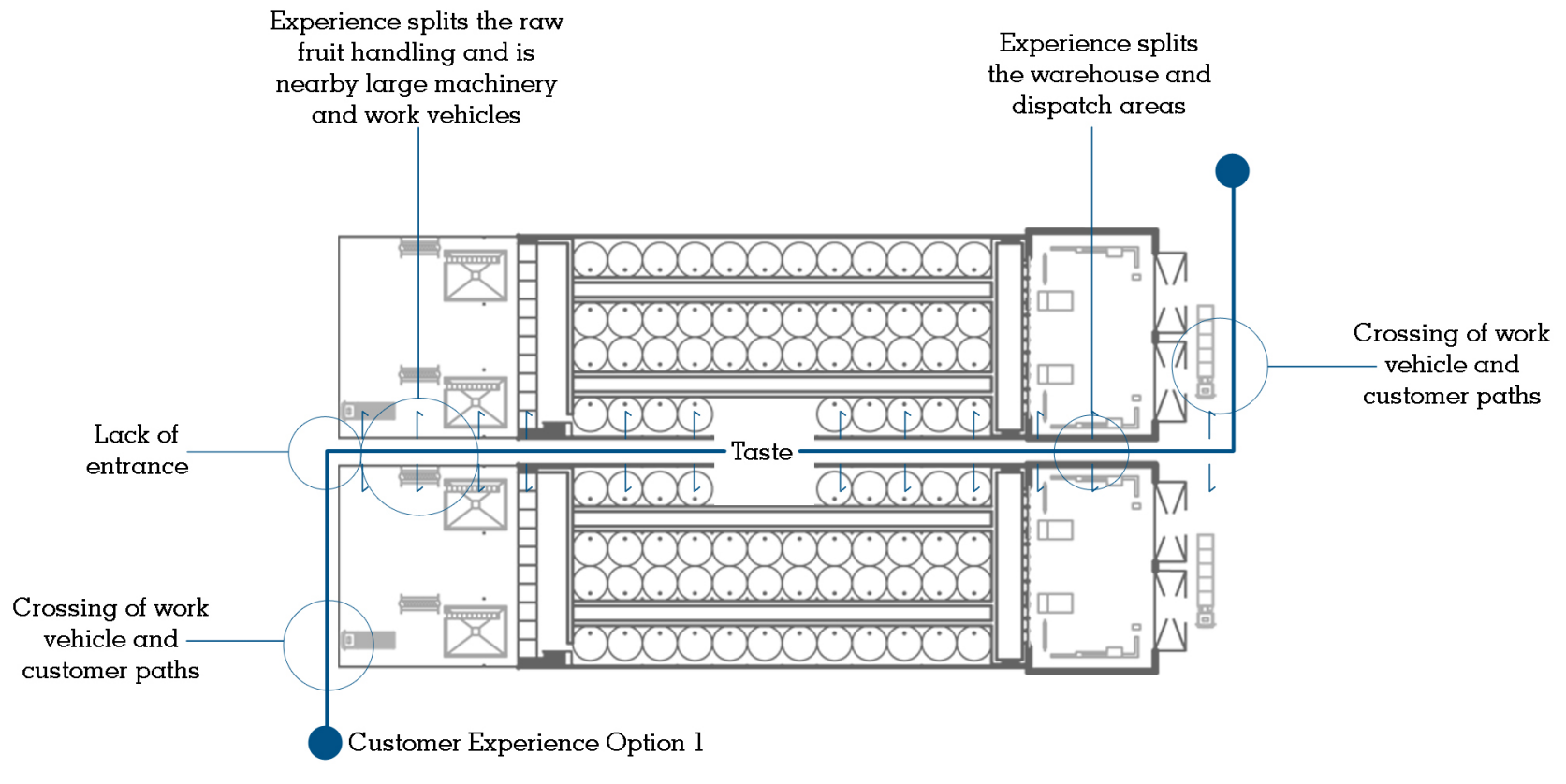

Fig 7.2 Parralel Experience Diagram

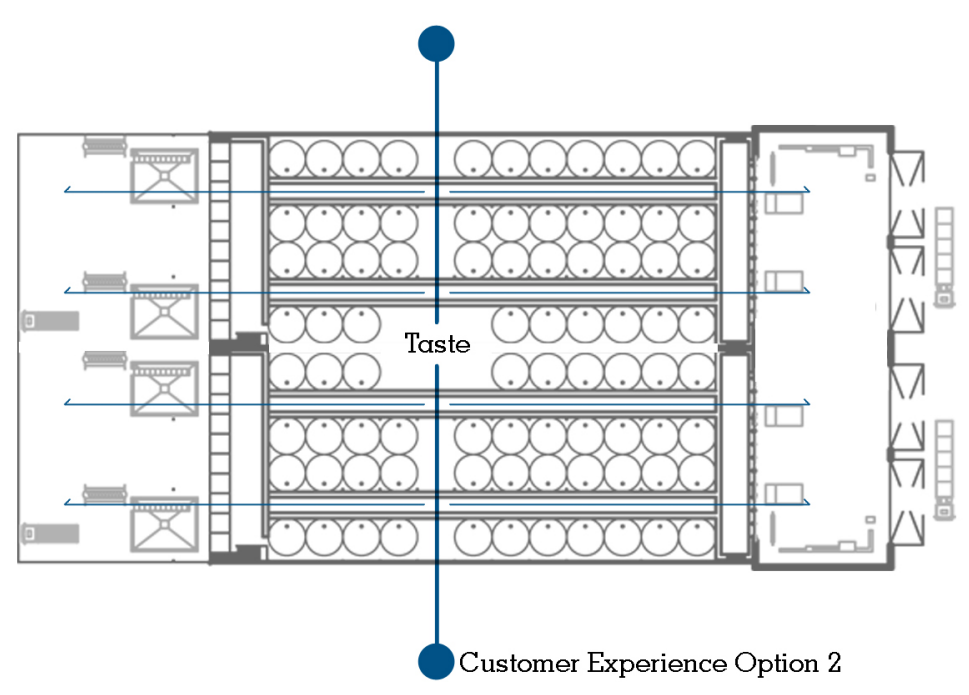

Fig 7.3 Perpendicular Experience Diagram
There are two main options with form the basis of incorporating the winery experience into the process.

(1) The experience runs parallel with the process meaning that the customer gains a more up close experience with each of the parts of the process however risks hazards from crossing paths with large machinery and work vehicles. The experience would also split parts of the process in turn effecting the efficiency of the production facility.

(2) The experience runs perpendicular to the process meaning that the customer does not effect the process at all. Experience is not as close up but possibly more interesting passing between fermentation tanks that frame viewpoints to the fruit handling and warehouse and dispatch areas. 


\subsection{EXTERNAL EXPERIENCE}

There are two main exterior features that the public see on arrival to the Product Experience. However these architectural features are not driven by the experience, more so by the functionality of the building. The process requires access from the raw fruit handling to the fermentation five metres down and this is done through a ramp (1).

This in turn exposes the full size of the tanks and gives an insight into the huge size of the production scale that Pernod Ricard are operating with (2)

To retain the soil caused by the hole a use of a gabion wall filled with Wairau river stones not only holds the soil but makes reference to Marlborough's terroir. The gabion wall continues into the building essentially connecting the land with the production facility (3).

90
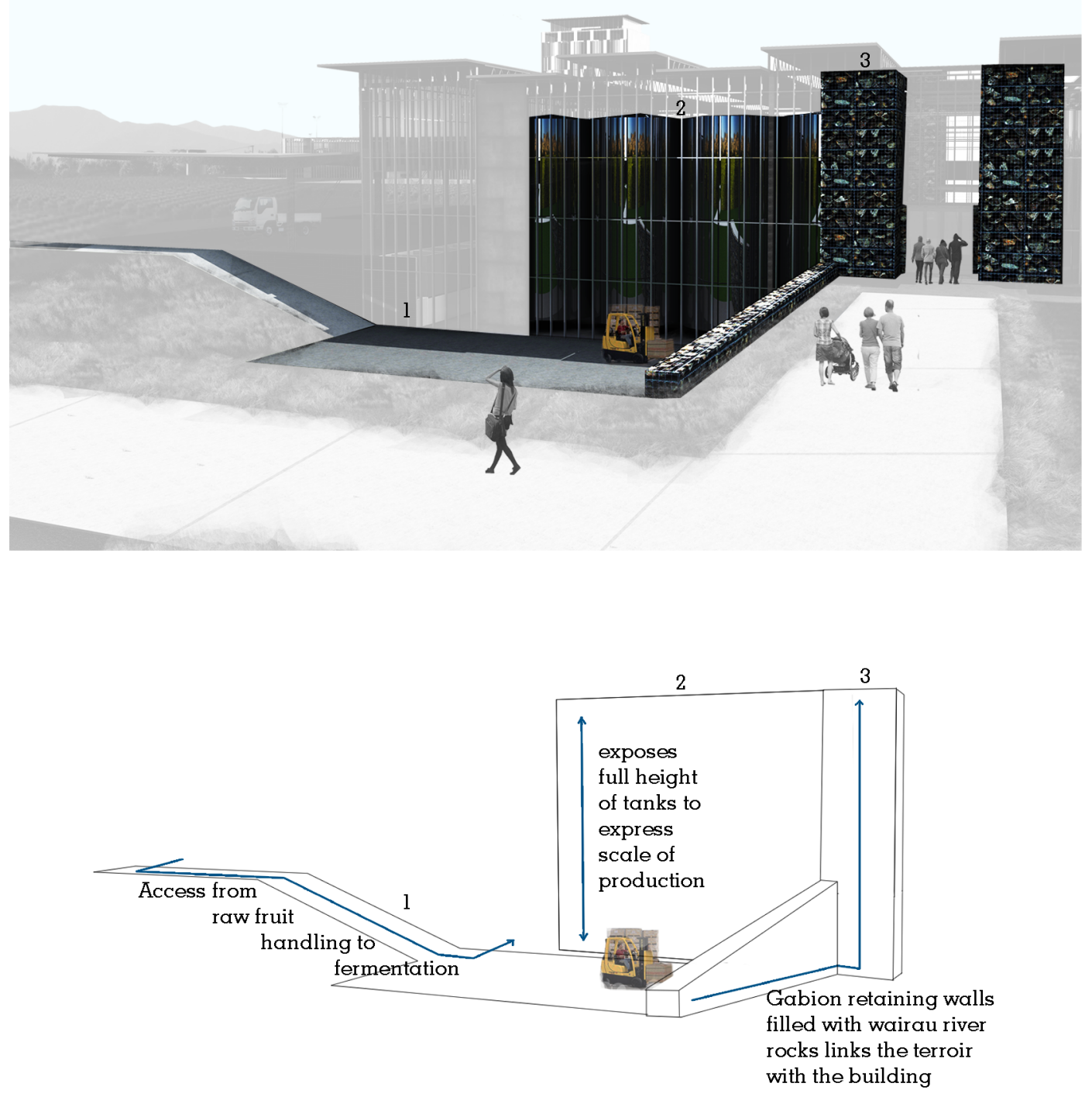

Fig 7.4 External Product Experience Diagram 


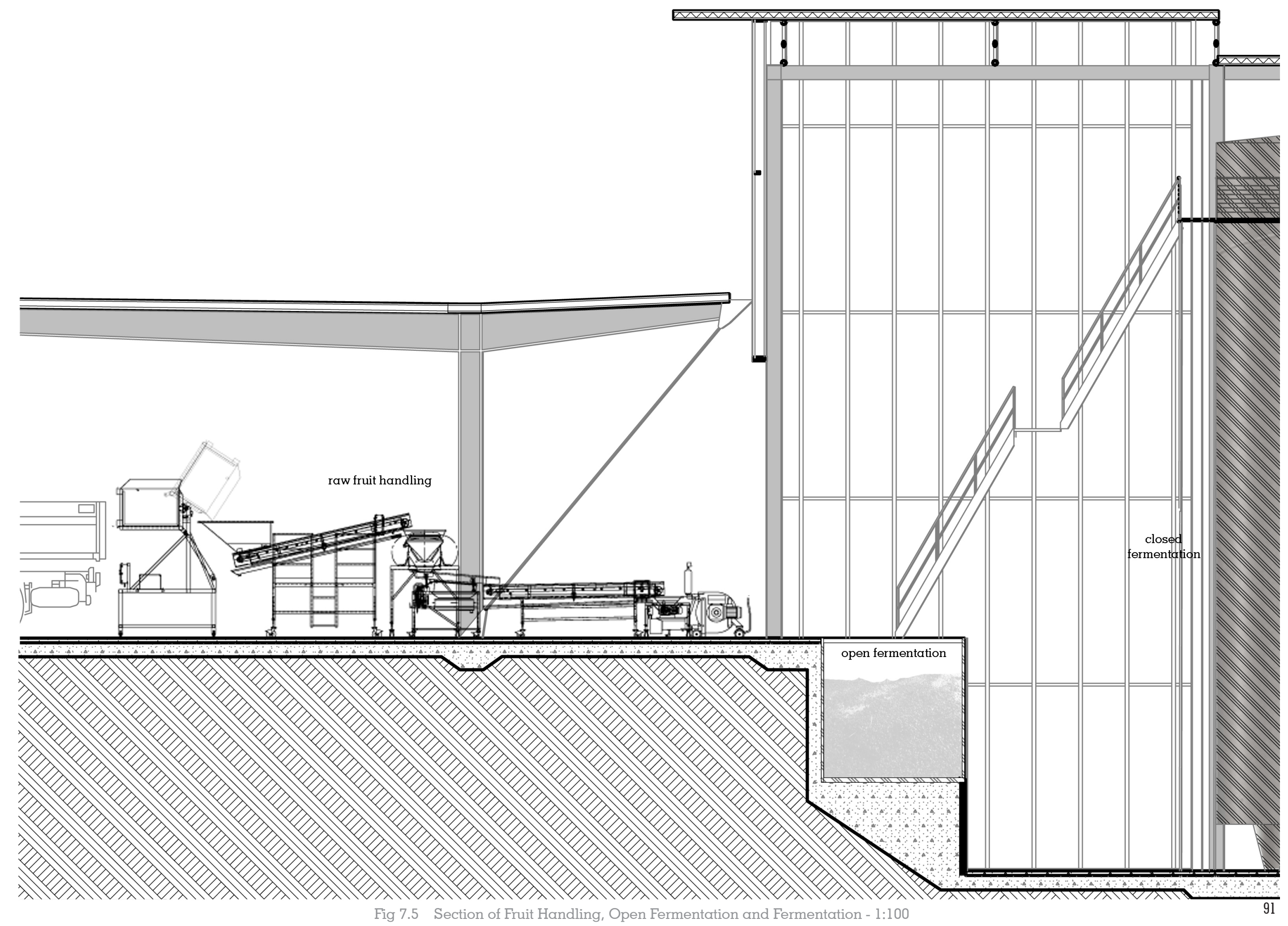




\subsection{INTERNAL EXPERIENCE}

There are two main internal features that engage the public with the process in the Product Experience.

The first feature is a continuation of the gabion walls into the building. These walls are able to help explain through smell and touch because of the breathable properties of the walls. Smells and the coolth of the fermentation rooms pass through the gabion walls into the tasting room educating the visitor in different sensual aspects (1).

The second feature is the extensive use of glass and steel which not only exposes viewpoints into the facility and other parts of the process but also speaks the industrial quality of Pernod Ricard as a wine producer

(2). It also reveals the huge fermentation tanks further reinforcing the scale of their company

(3).
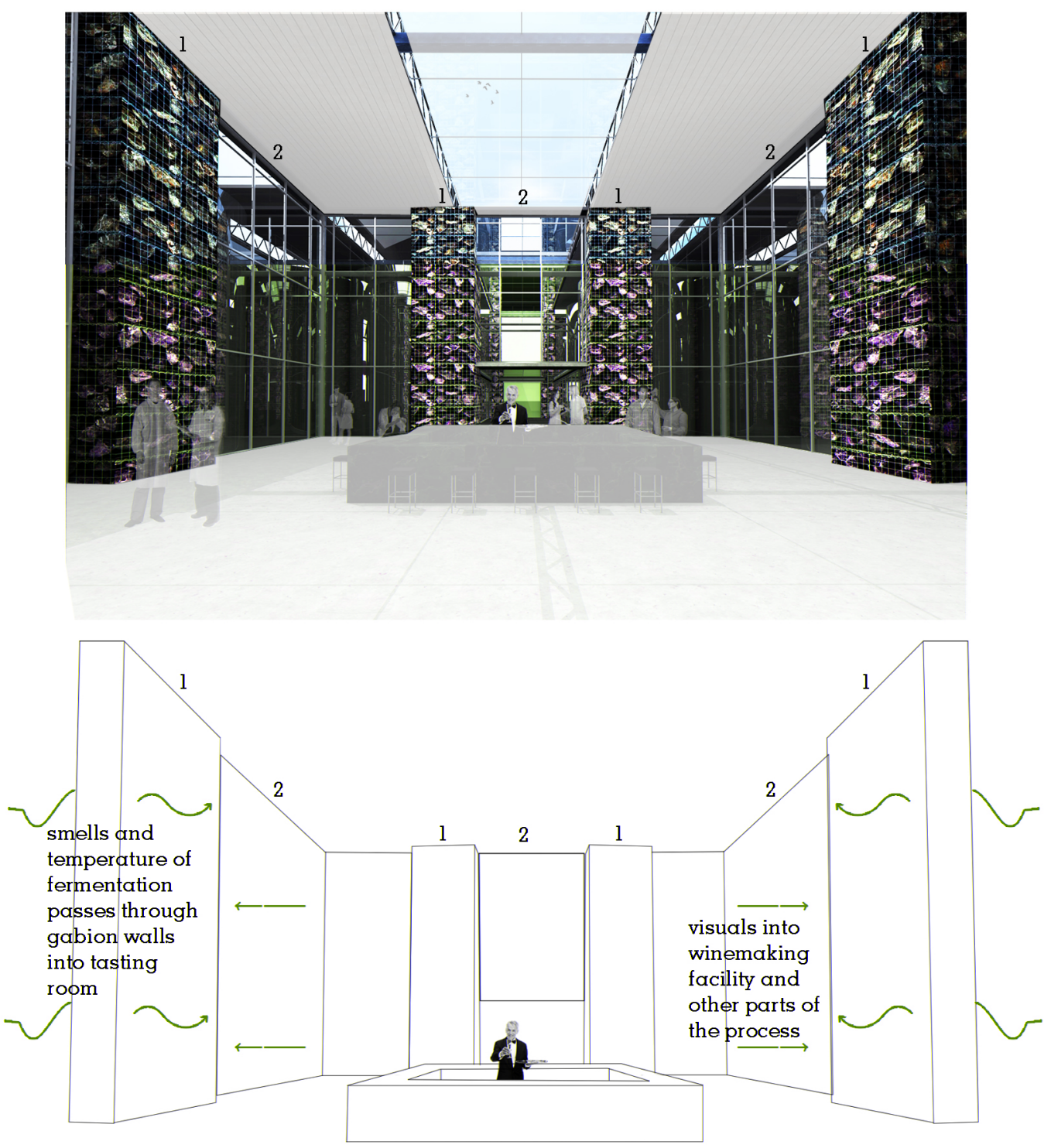

Fig 7.6 Internal Product Experience Diagram 


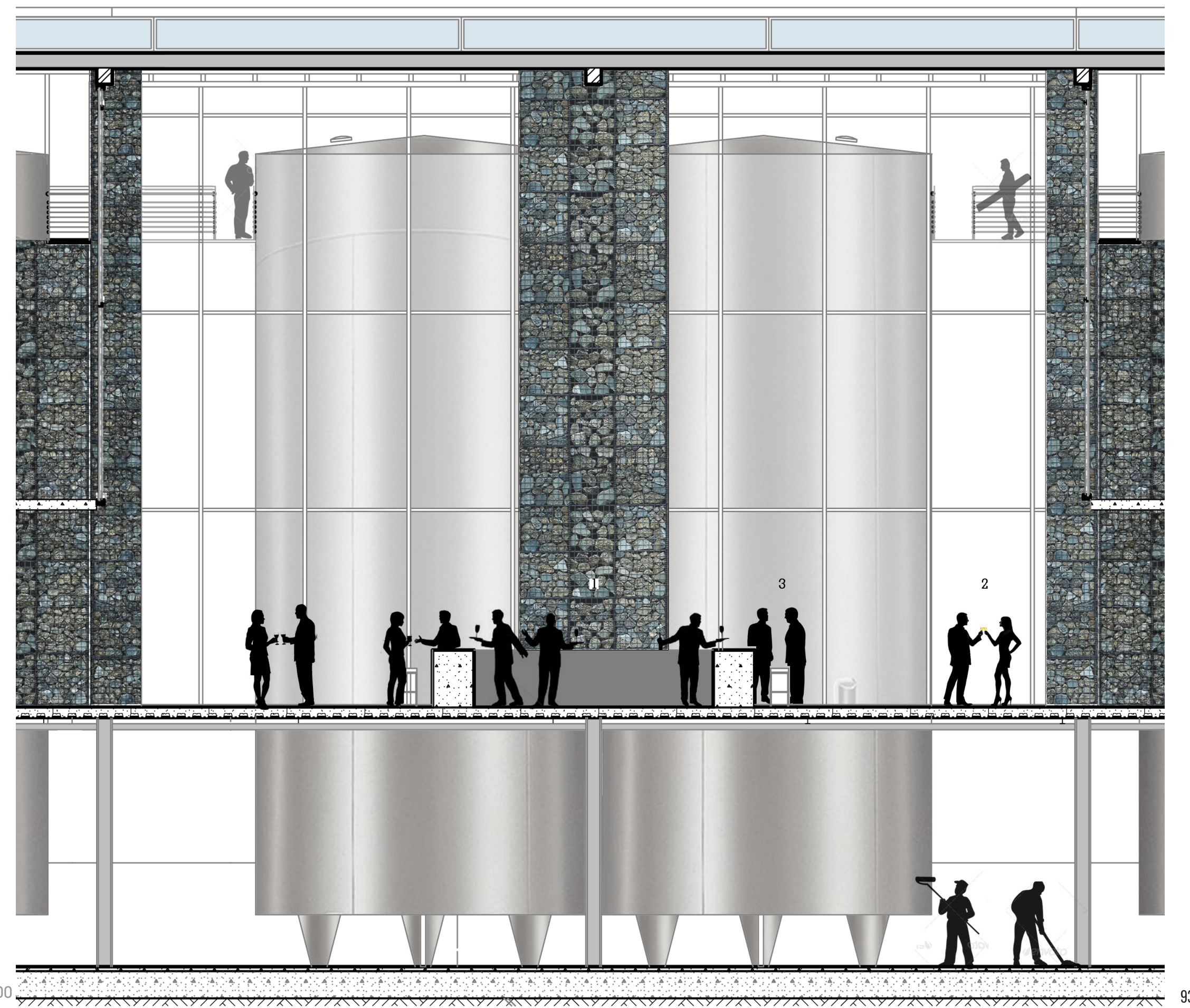




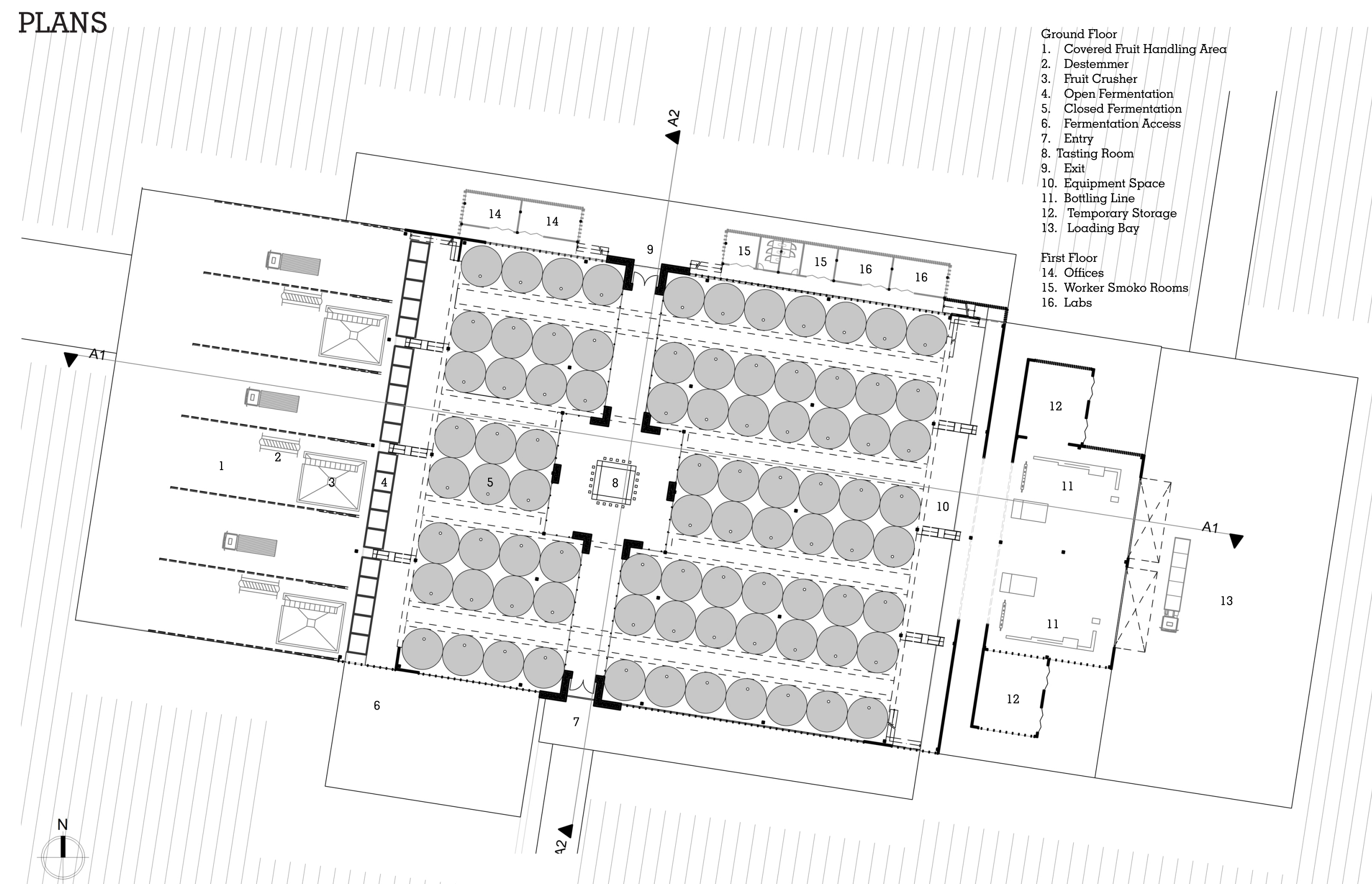


SECTIONS

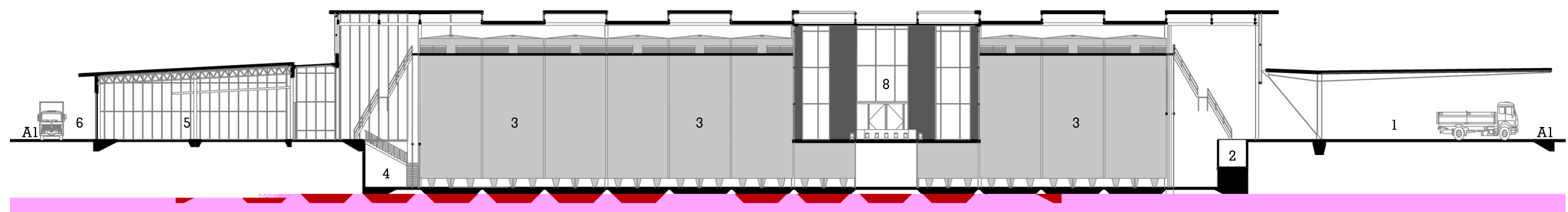

Production

1. Covered Fruit Handling Area

. Cermentation

3. Closed Fermentation

4. Equipment Spa

5. Bottling Line

Experiente
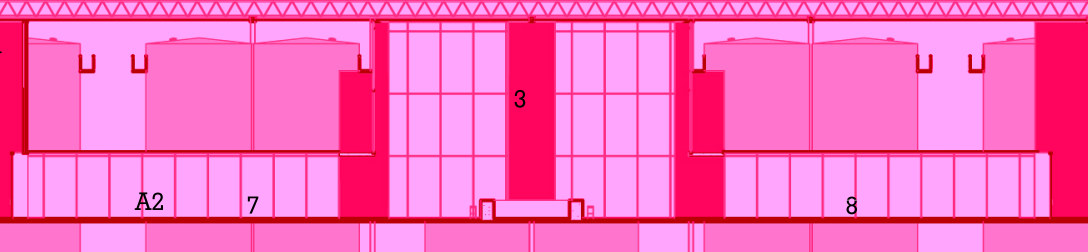

7. Entry

8. Tasting Room

9. Exit

10. Toilets 



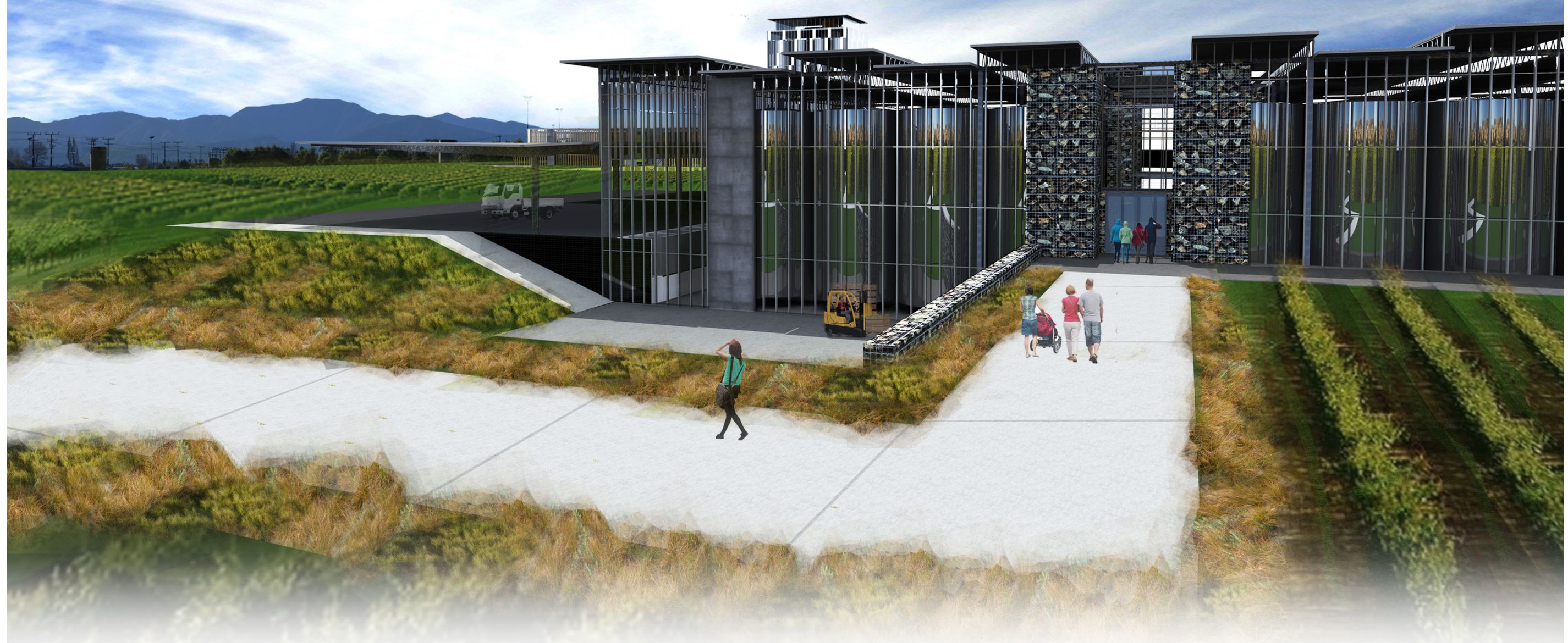




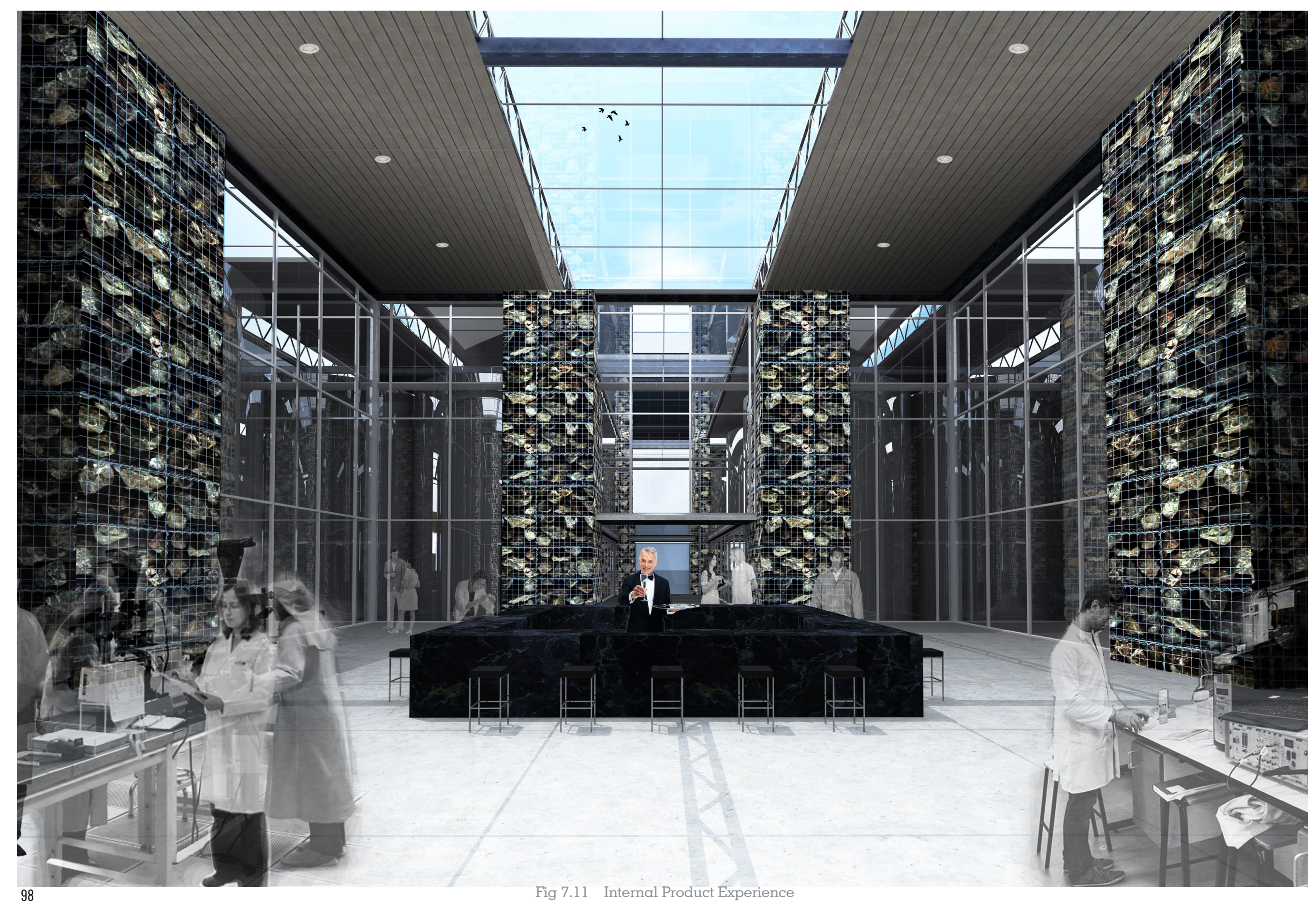





\subsection{COPORATE VALUE TWO - Planet}

The section showcases key features of the planet experience using images and diagrams to explain how the planet corporate value is communicated. 


\subsection{PLANET MASSING + LAYOUT}

The floor area of the tower is key to generating the image of a tower. The smaller the area the taller the tower will seem however this creates scalable problems with the production building due to the difference in grains of the buildings.

By splitting the building into parts it reduces the scale of the production facility so that it is closer to that of the tower. This division also gives an opportunity to integrate green systems between buildings.

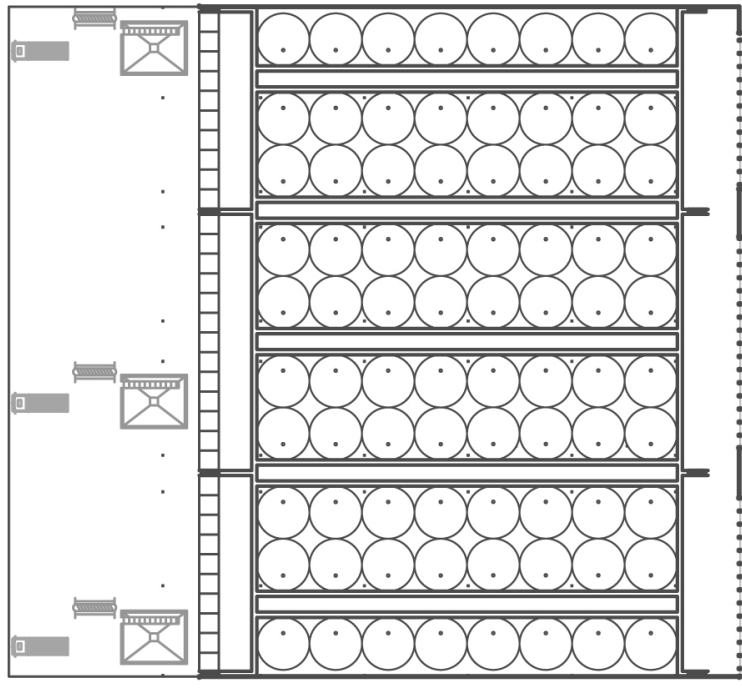

Fig 8.1 Massing and Layout Diagram before Change

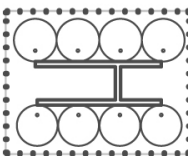

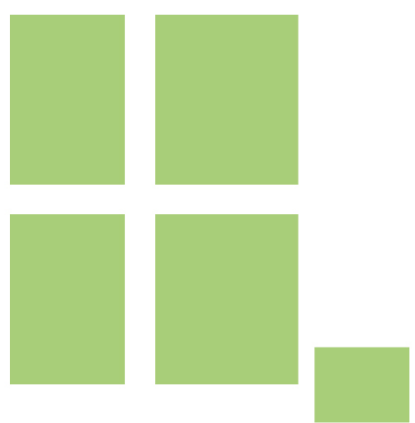
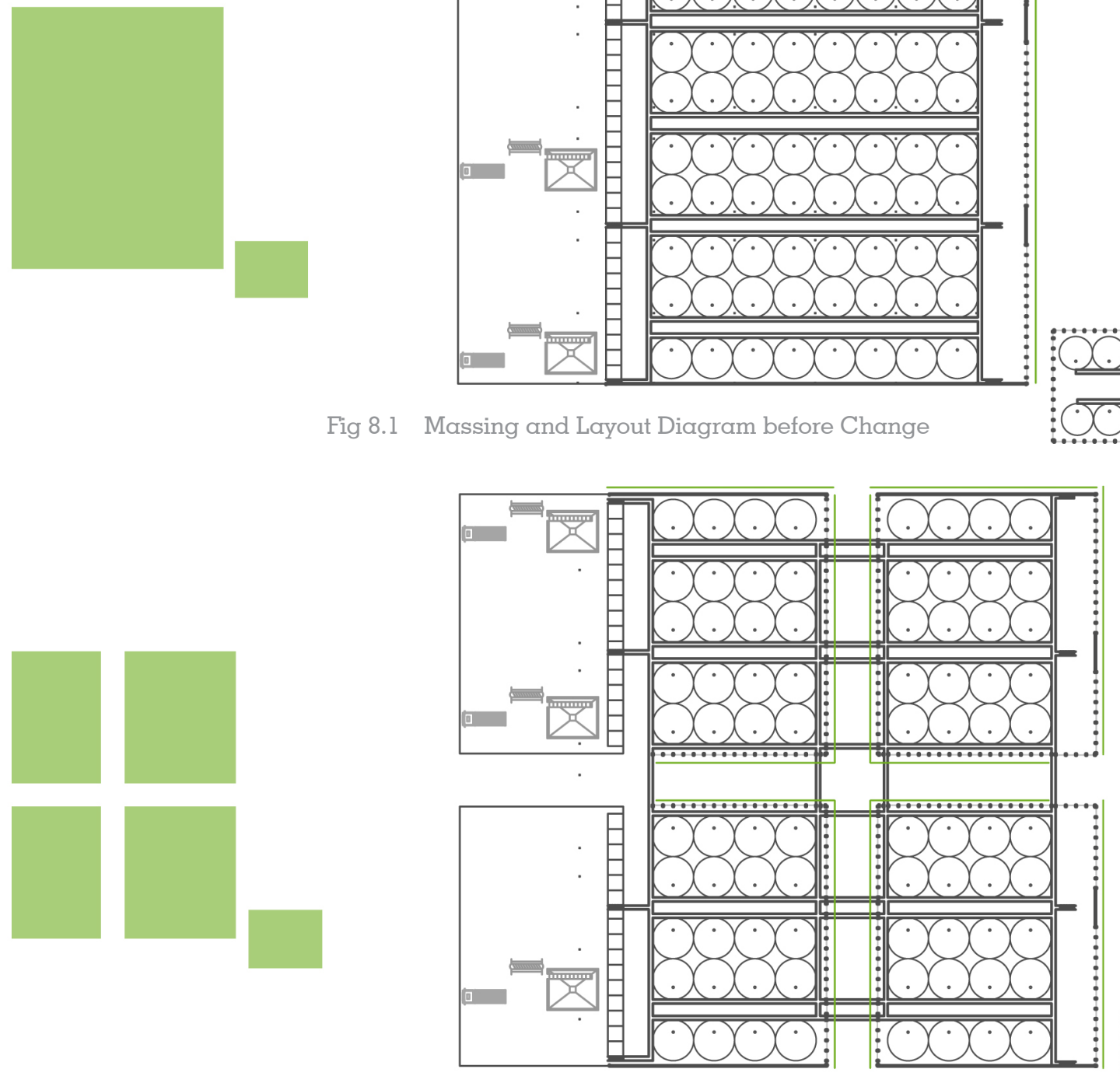



\subsection{EXTERNAL EXPERIENCE}

From the roadside there are three features that advertise Pernod Ricards commitment to combining environmental awareness with wine production.

The first is the tower which is a partly reflective, partly transparent glass facade. This acts as a landmark in the Marlborough region and directly combines the planet through reflections with transparency showcasing the production tanks (1).

The green walls are used because they not only demonstrate commitment to the planet but also because of the thermal properties that they possess which can help keep the tank rooms at moderate temperatures (2).

The wetlands are created from the extensive water run off that is used in cleaning fermentation tanks (3).

104
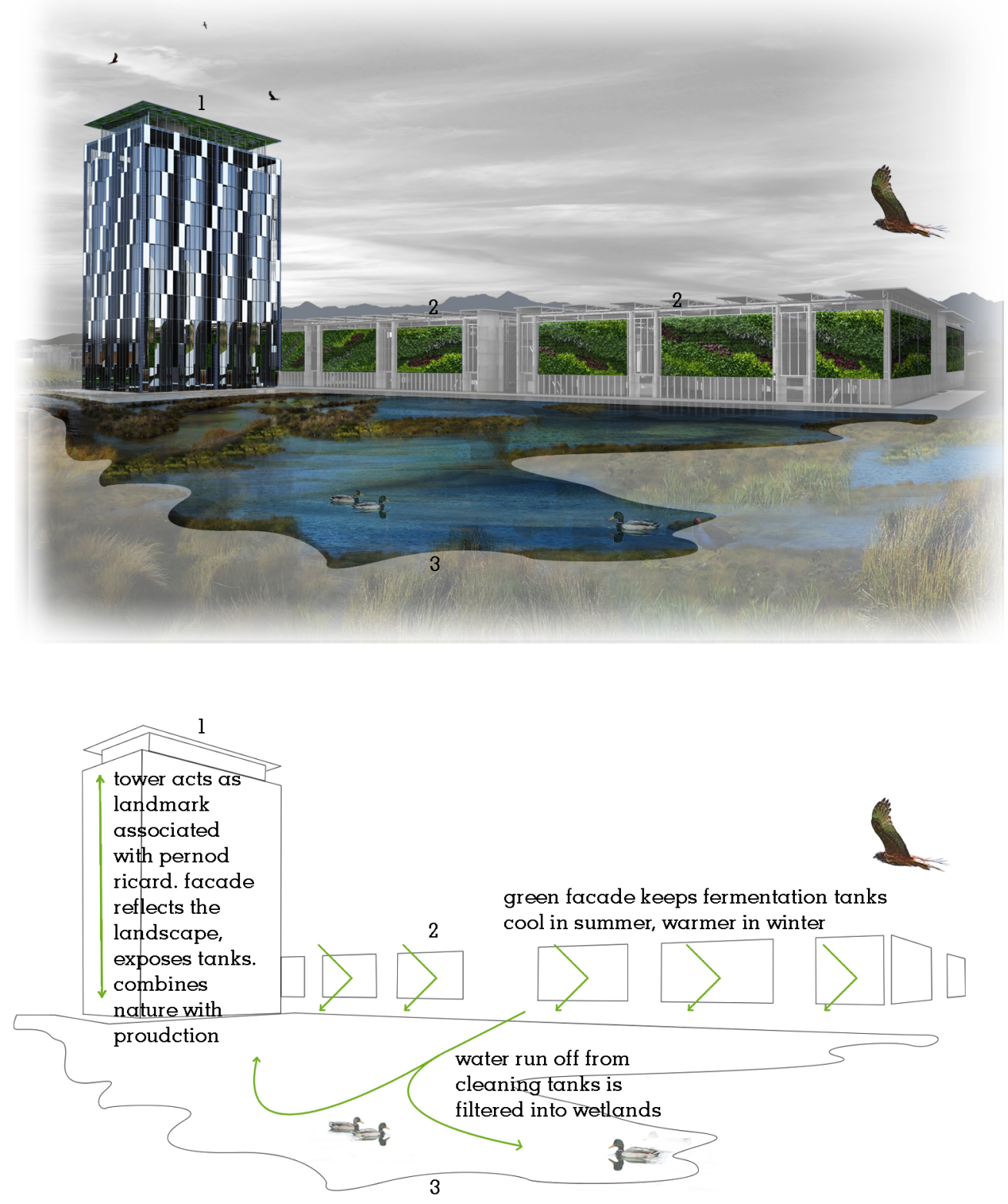

Fig 8.4 External Planet Experience Diagram 


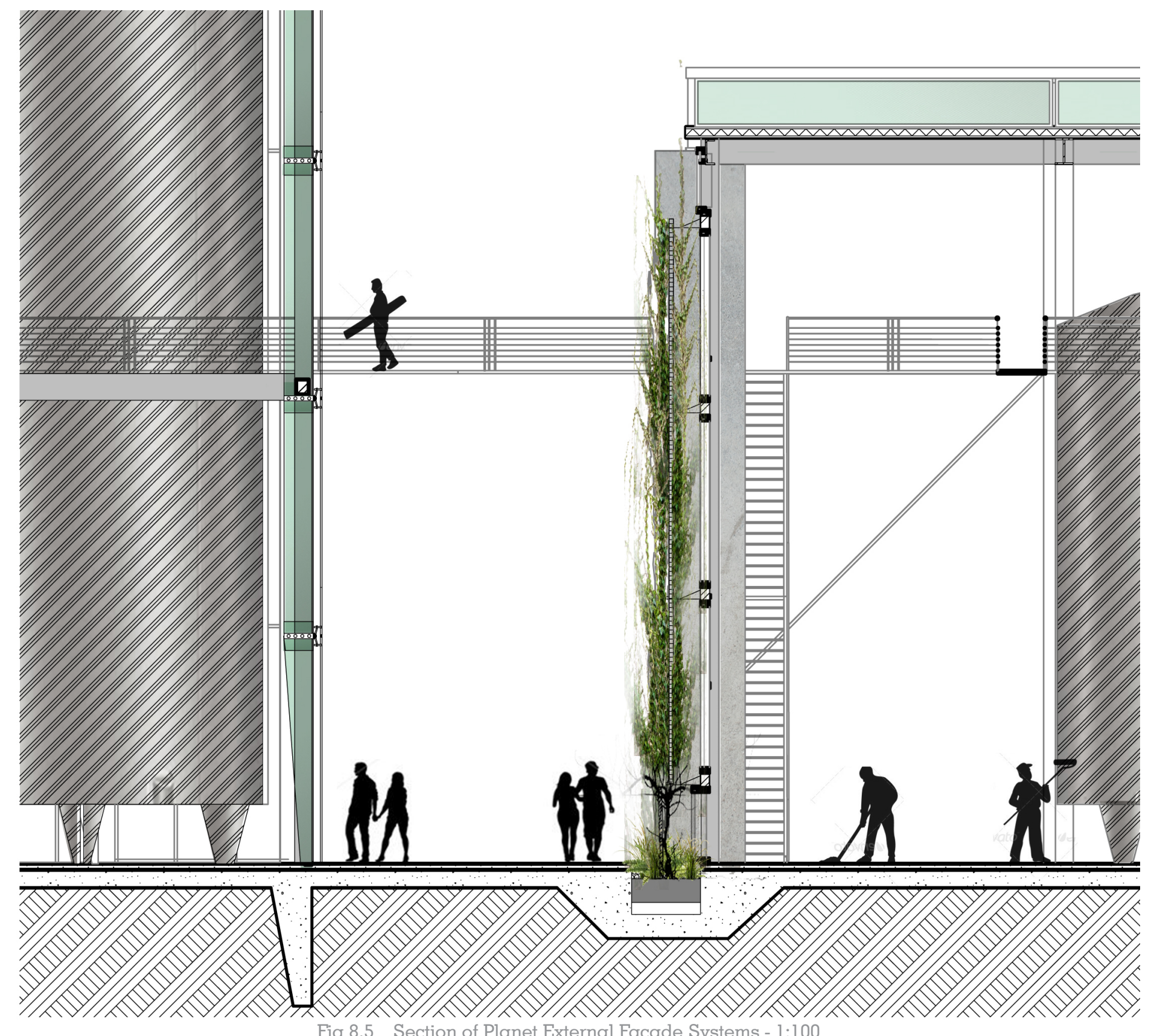




\subsection{INTERNAL EXPERIENCE}

The planet tasting room is located at the top of the tower and is accessed through

a glass elevator that ascends amongst the fermentation tanks.

The tower provides a 360 degree visual experience showcasing the Marlborough region (1).

The glass facade's reflective qualities breaks down the barrier between the planet and the building (2)

The LED roof during evening tasting extends out into the night sky further merging the building with the planet (3).
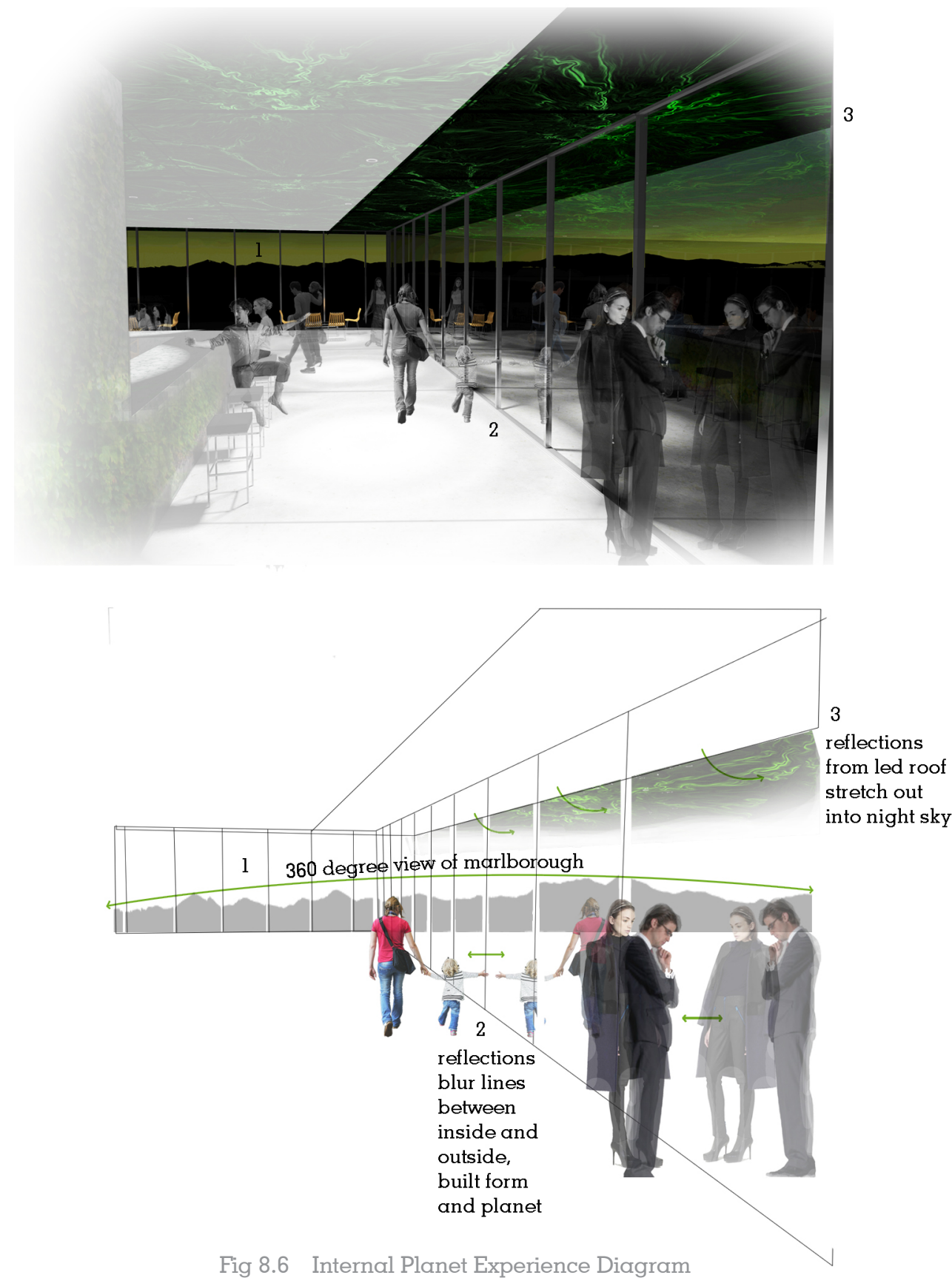


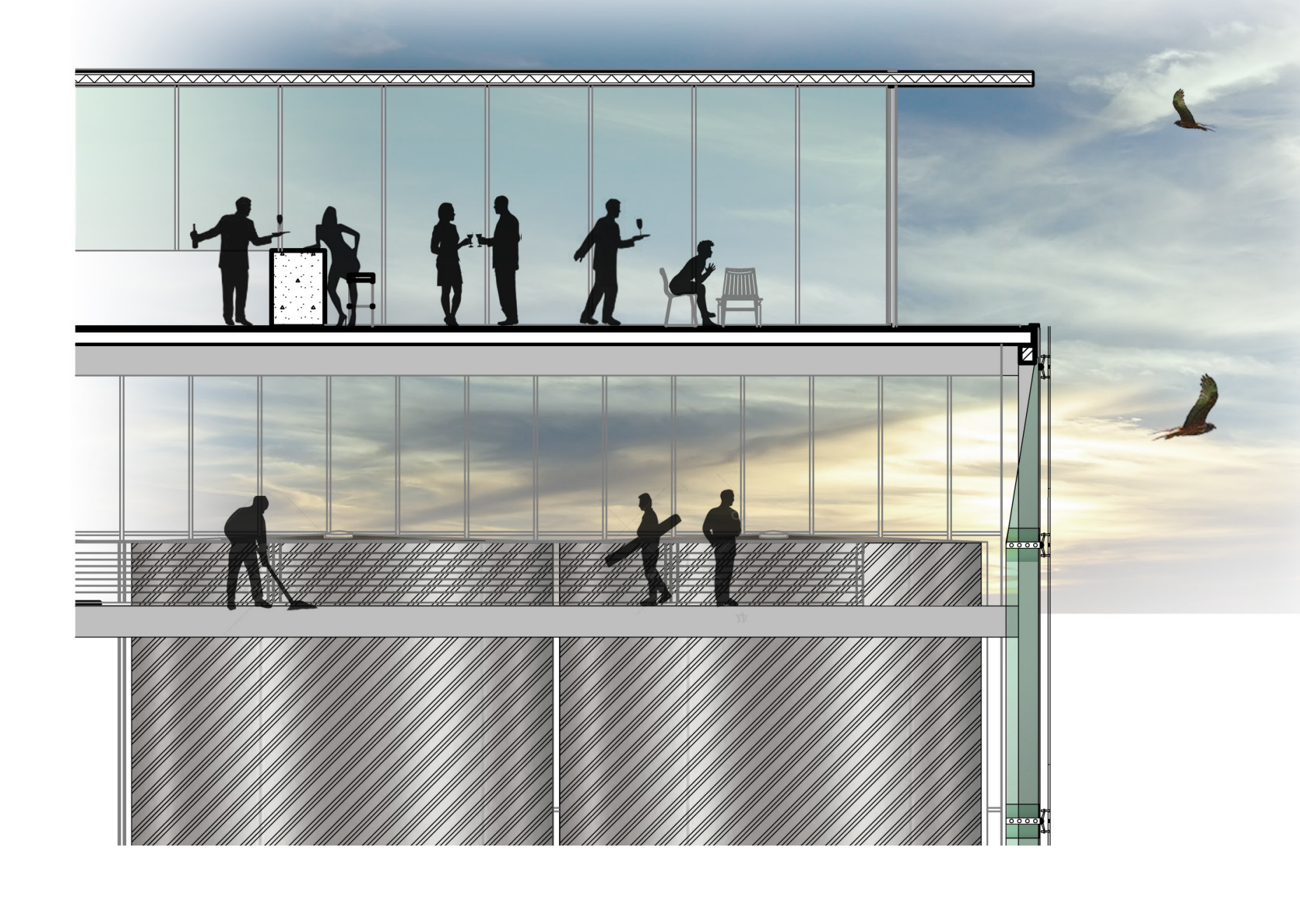




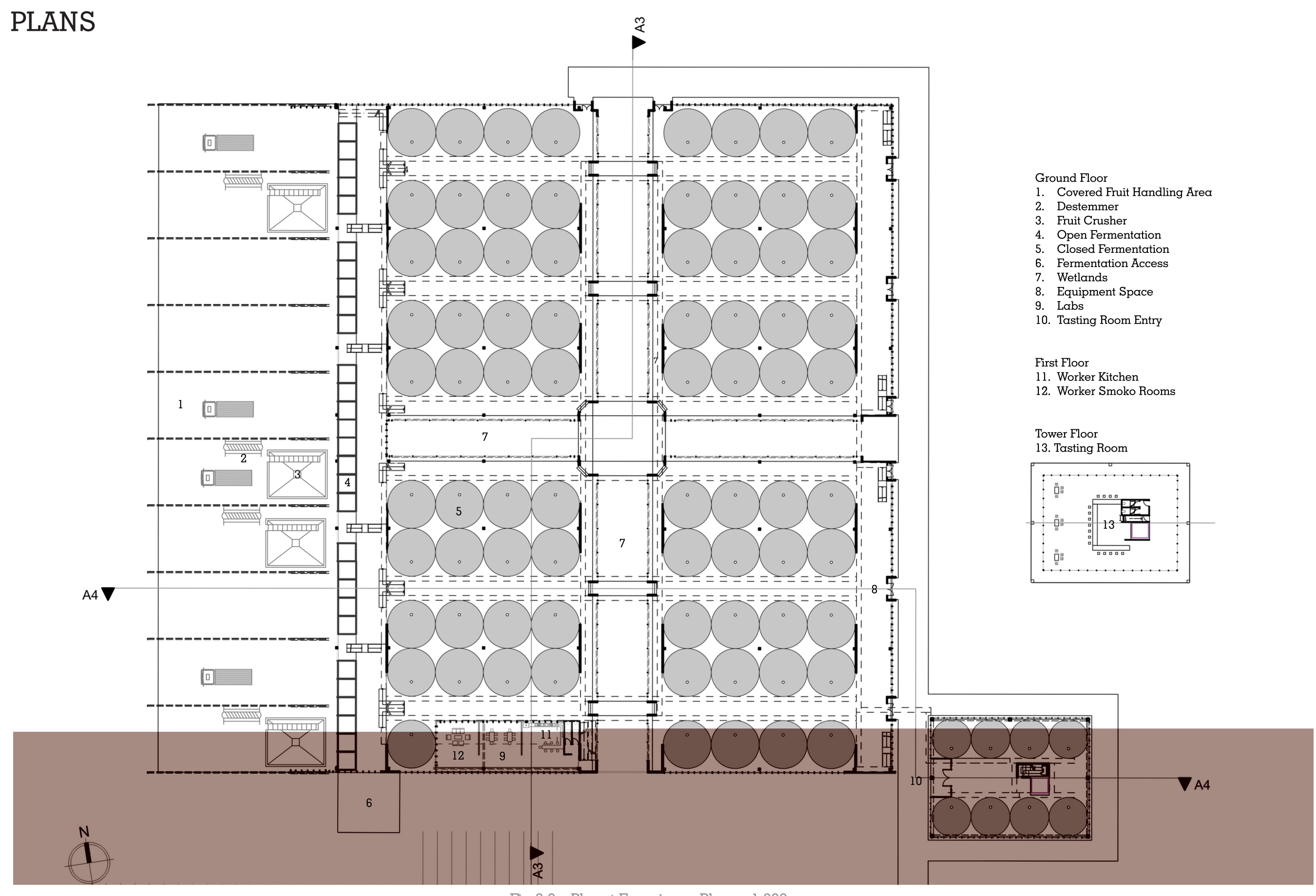




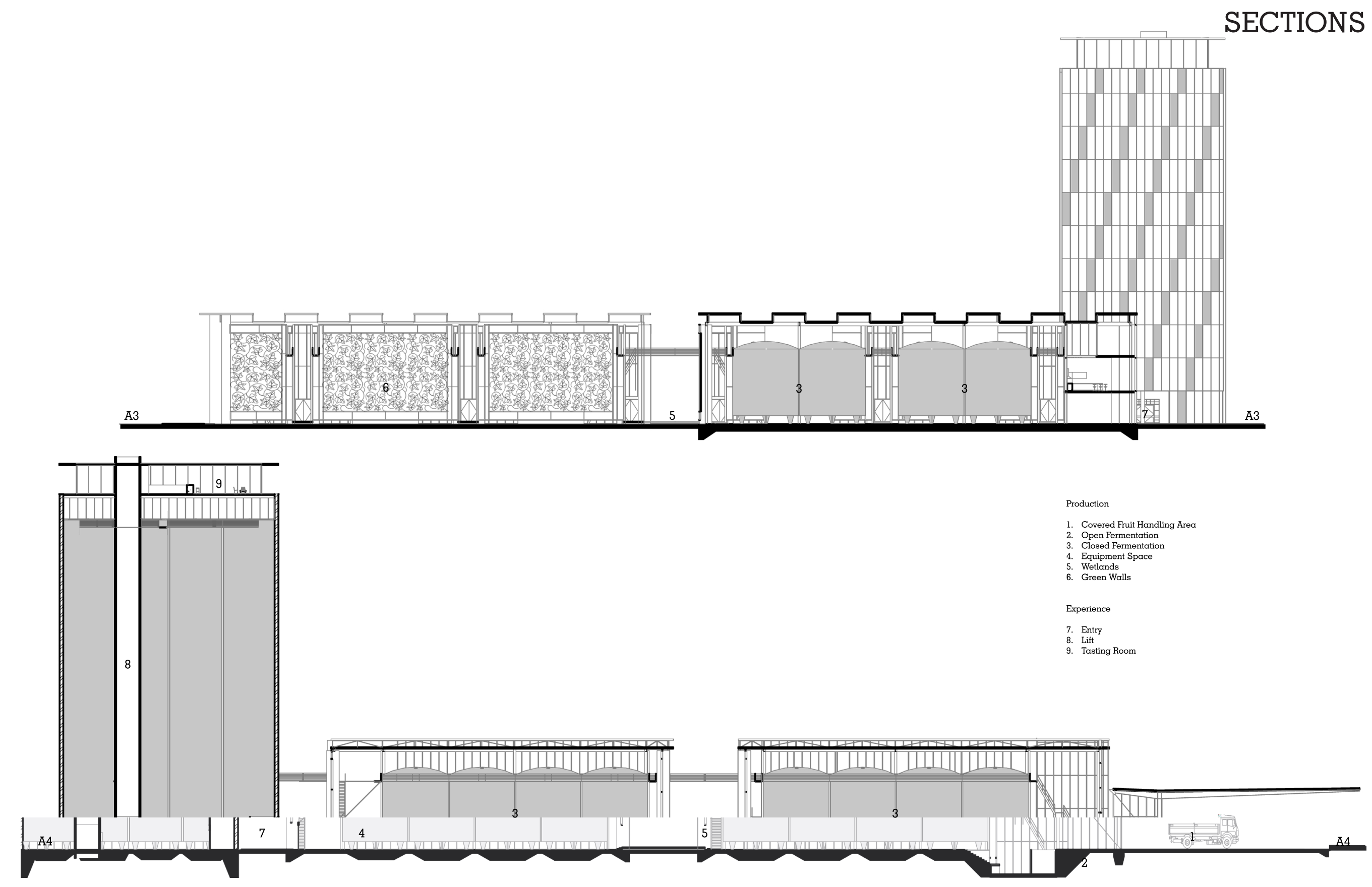




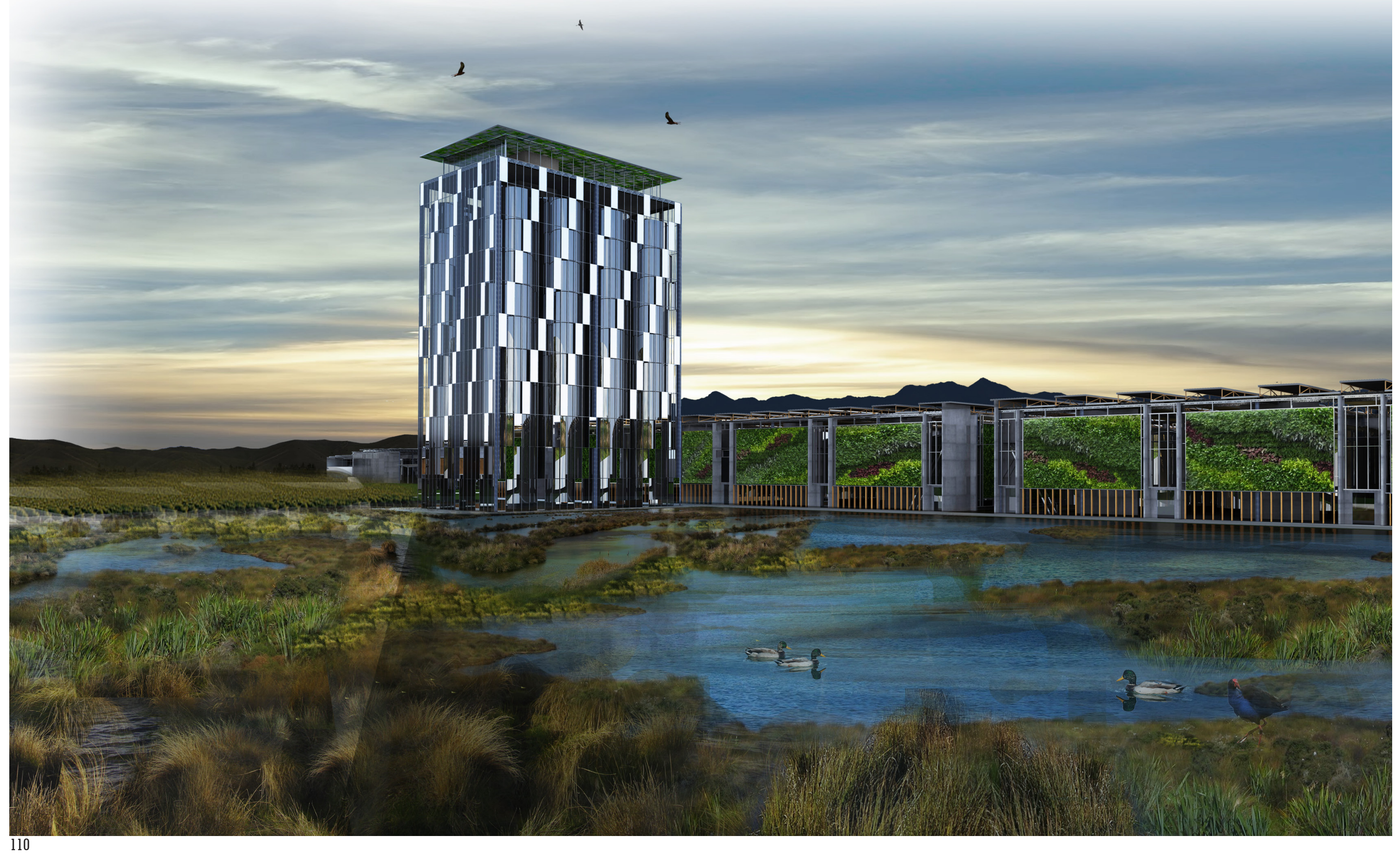



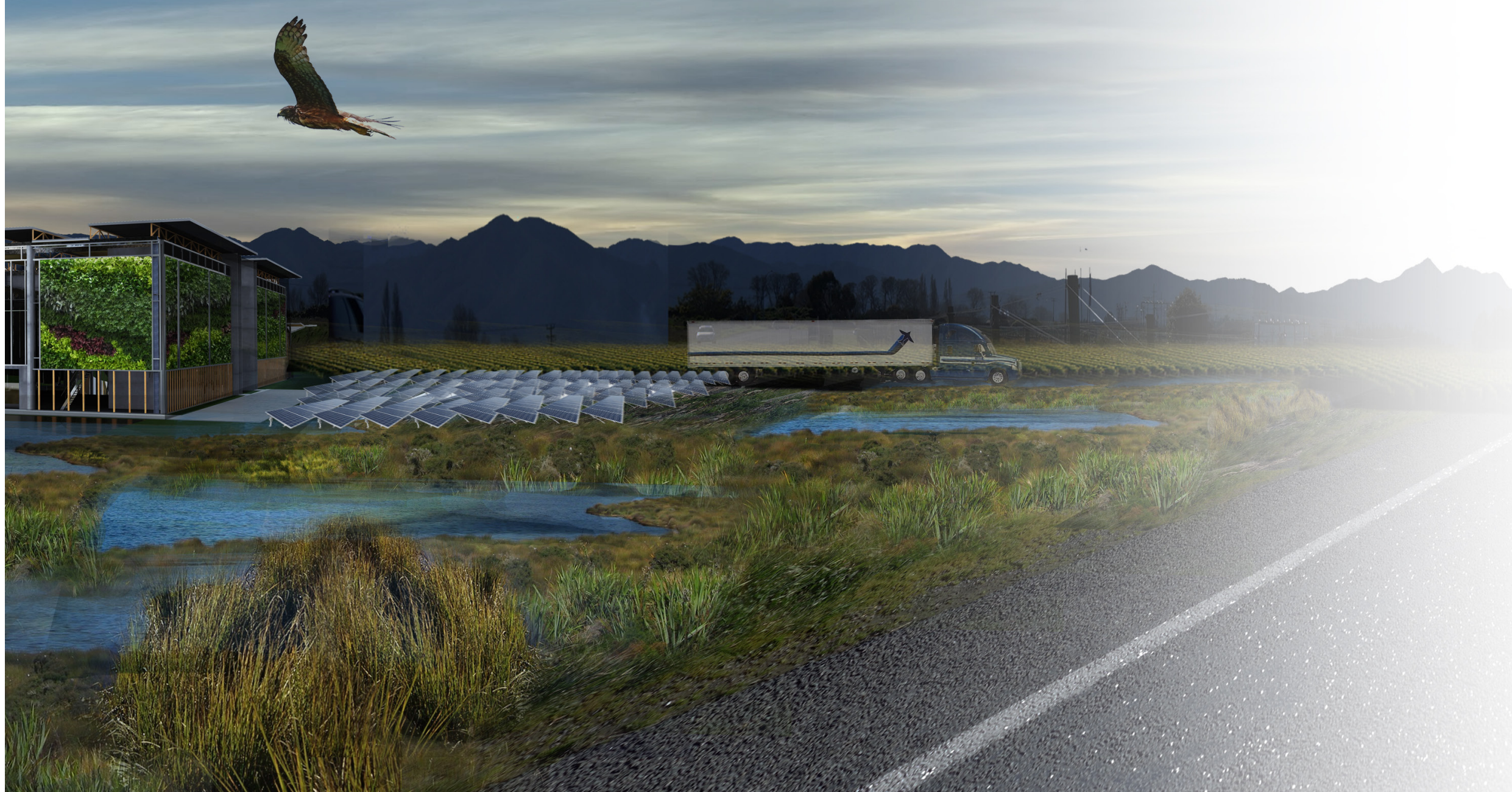


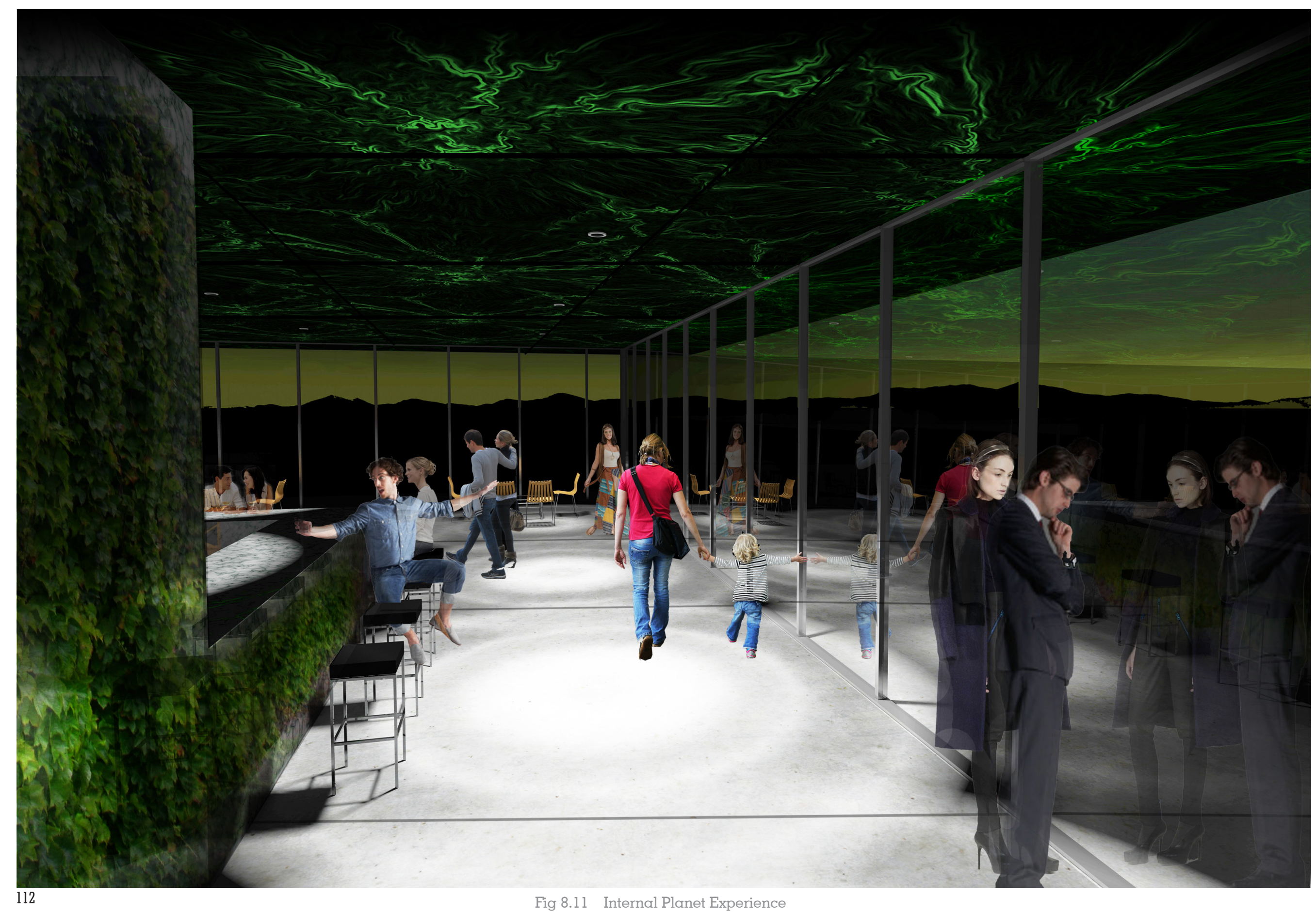




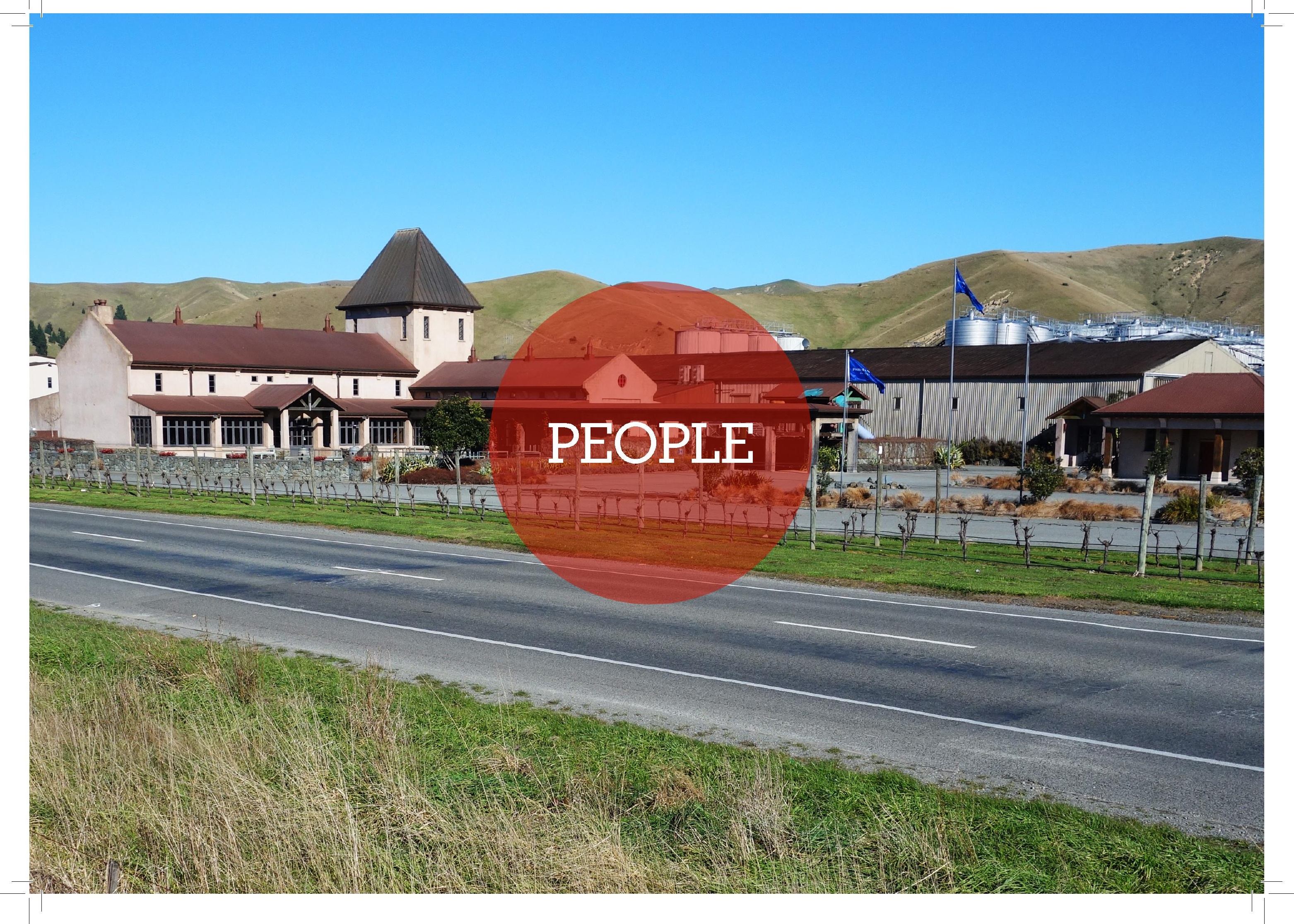




\subsection{COPORATE VALUE THREE - People}

The section showcases key features of the people experience using images and diagrams to explain how the people corporate value is communicated. 


\subsection{EXTERNAL EXPERIENCE}

The product facility utilizes a curved form representative of the landscape. The curved form houses the barrels shielding them from the sun and keeping them cool (1).

It also acts as a roof for the tasting and restaurant while also providing spaces for human interaction (viewing platforms, shade, interaction, performance) (2).

Lastly the landform supports the viticulture school. In a literal sense the students themselves are working on the land while studying the land (3).
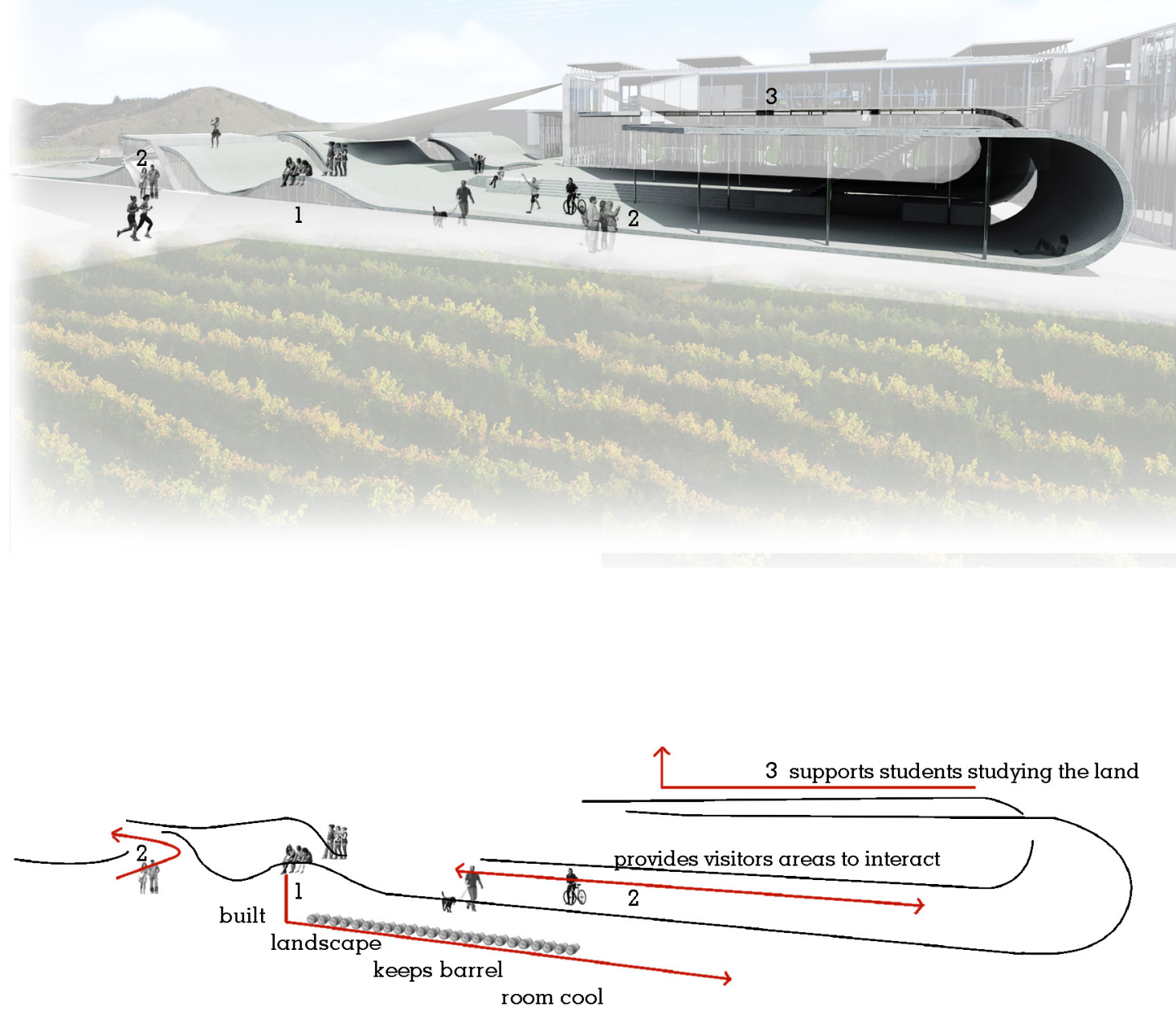

Fig 9.1 External People Experience Diagram 


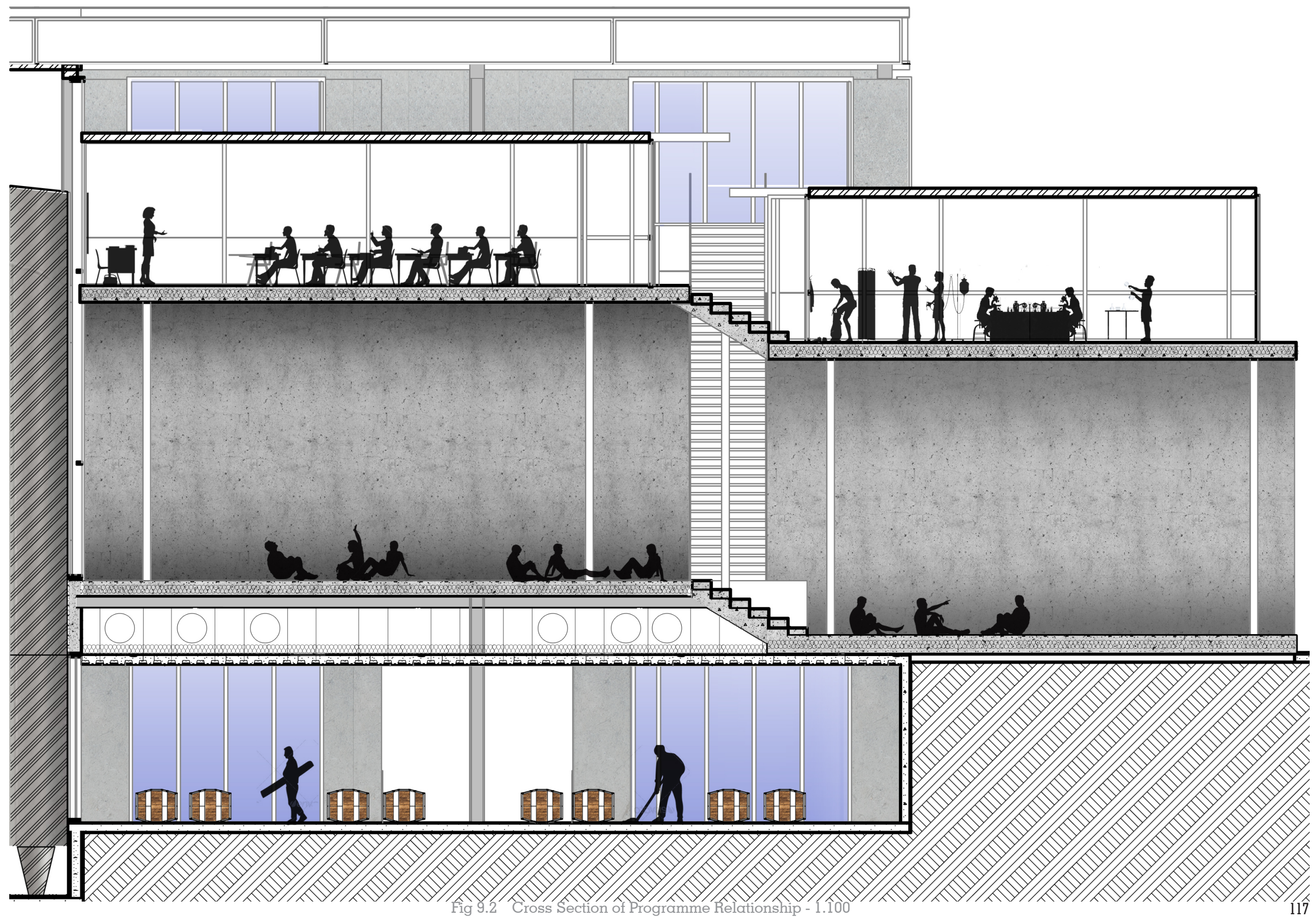




\subsection{INTERNAL EXPERIENCE}

The internal experience is largely through visual means. The undulating formwork of the concrete landform provides viewpoints into parts of the process $(1,2,3)$.

These viewpoints have coloured lighting able to be used to further enhance the experience during performances on the stage.
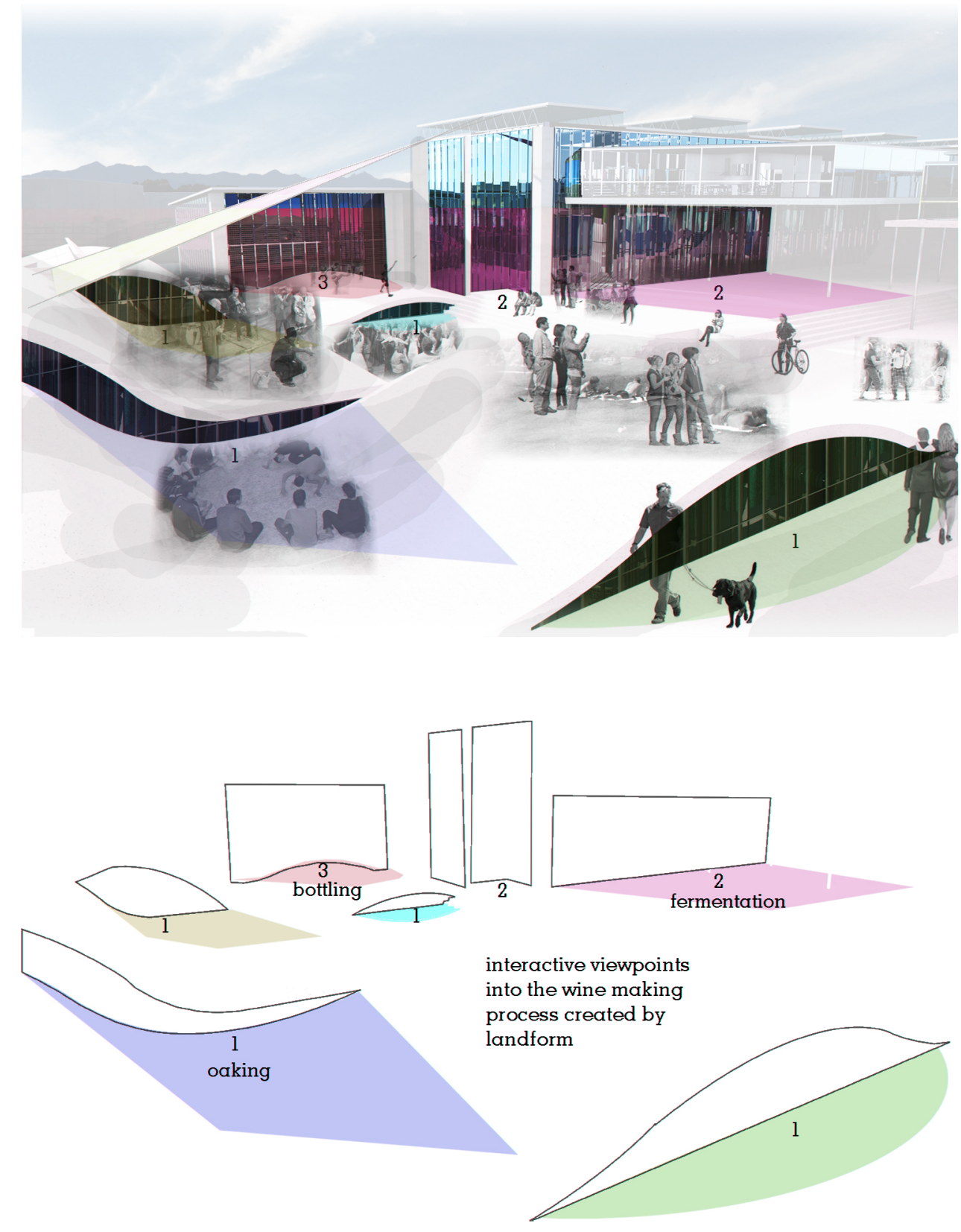

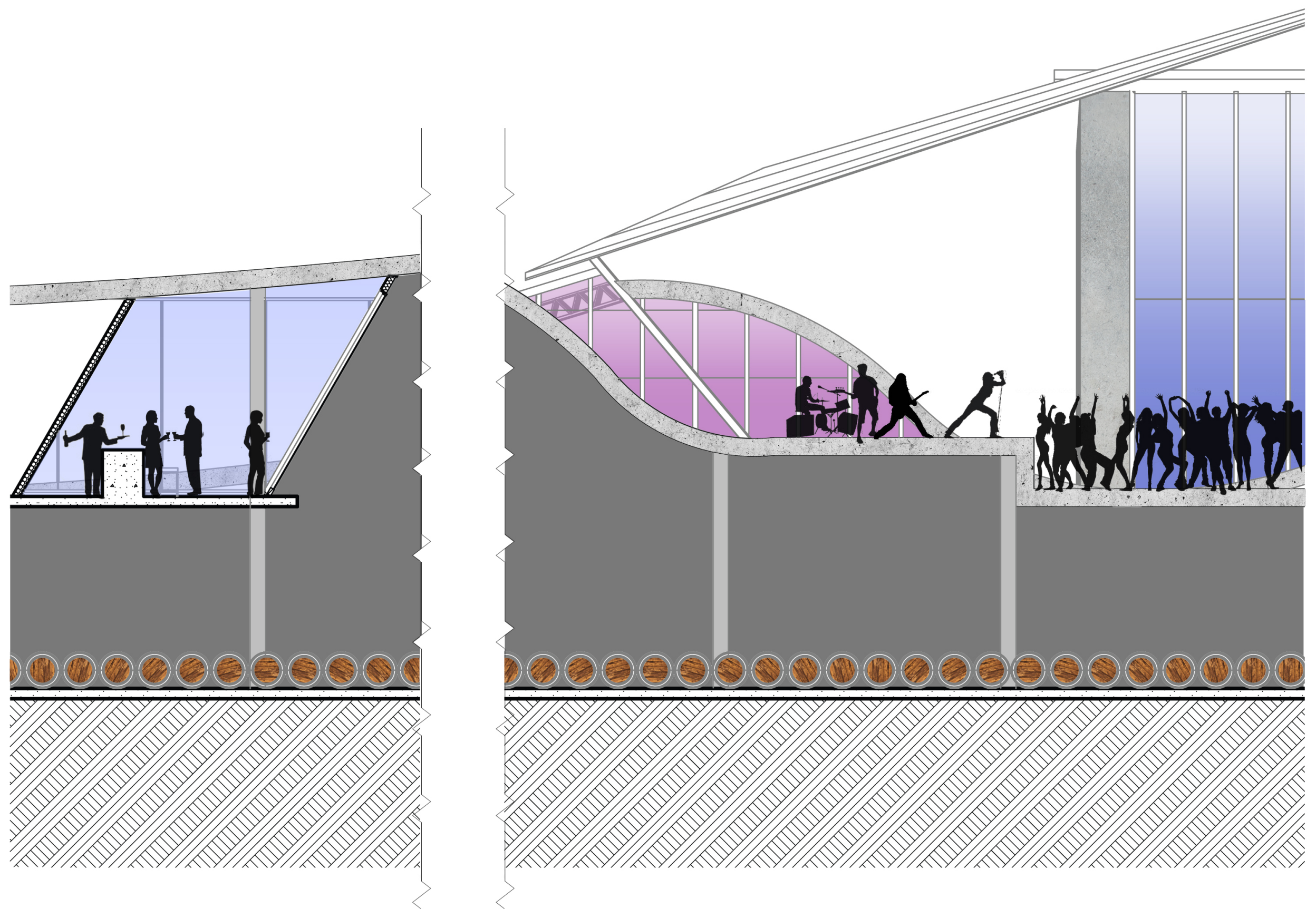


\section{PLANS}

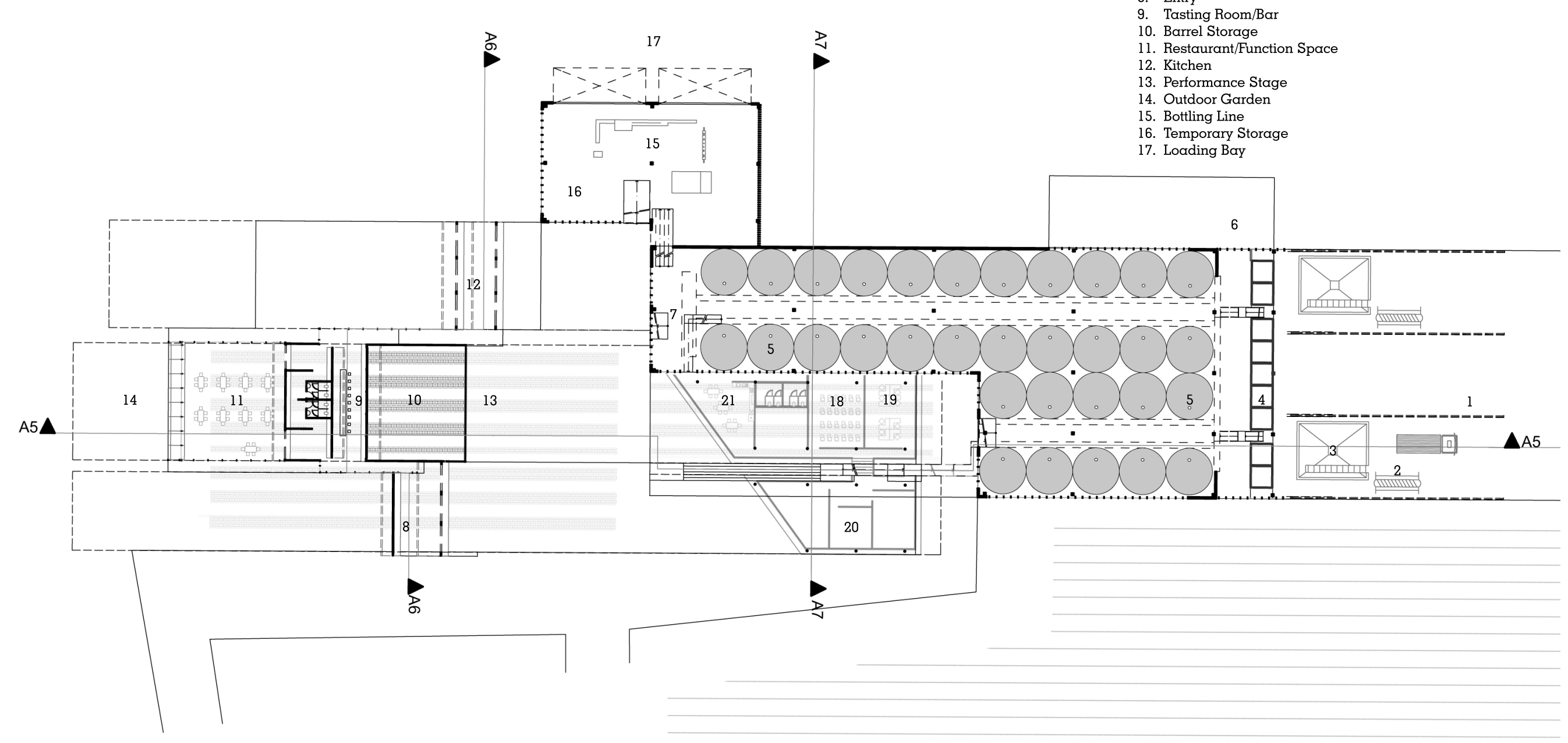

Ground Floor First Floor

Ground Floor

19. Classroom

3. Fruit Crusher

4. Open Fermentation

21. Smoko/Lunch Rooms

Closed Fermentation

Fermentation Access

6. Fermentation Access

Sub Floor

Sub Floor
10. Barrel Storage

staurant/Function Space 


\section{SECTIONS}

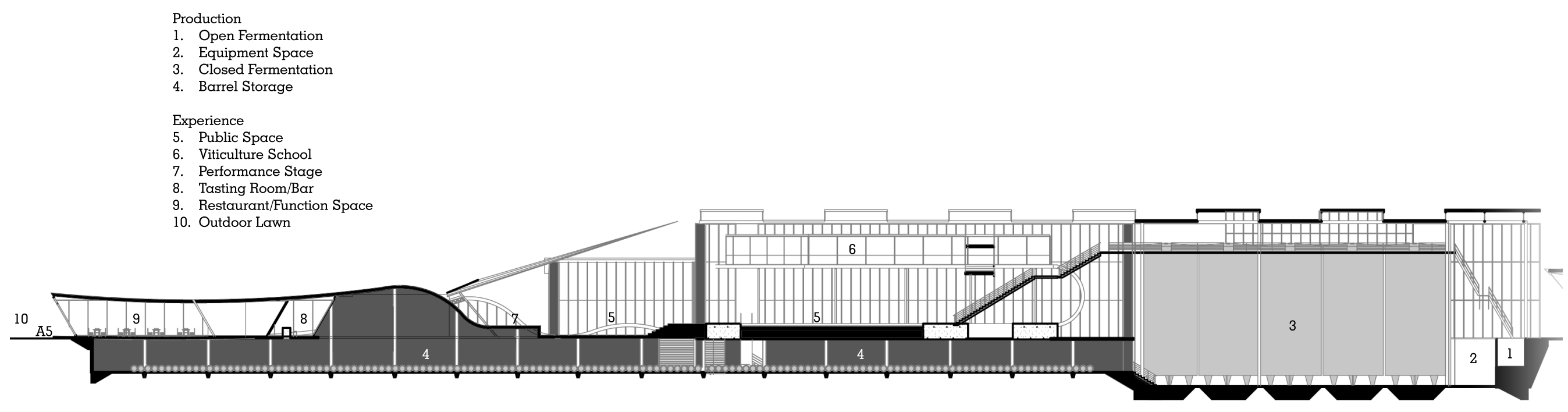

Production

1. Closed Fermentation

2. Barrel Storage

3. Bottling

5. Storage

Experience

Experience

Viticulture School

8. Entry

10. Kitchen

A6

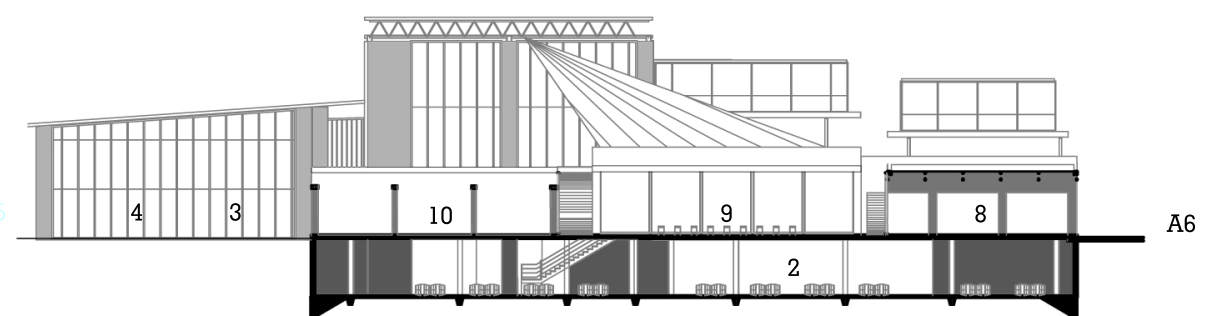

Production

Closed Fermentation

2. Barrel Storage

3. Bottling

5. Storage

Experience

Experience

Public Space

8. Entry

10. Kitchen

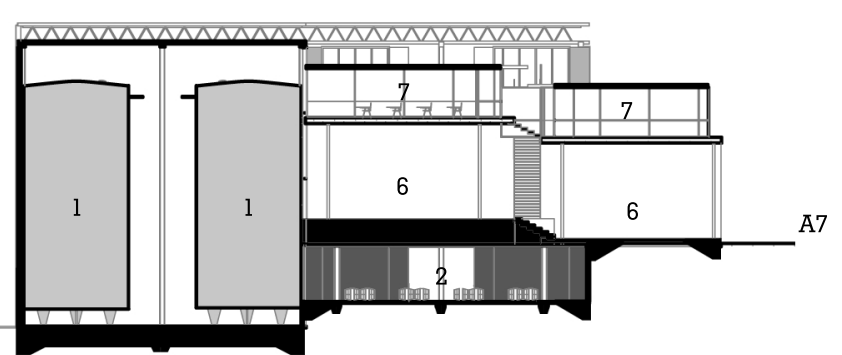




\section{$-$}
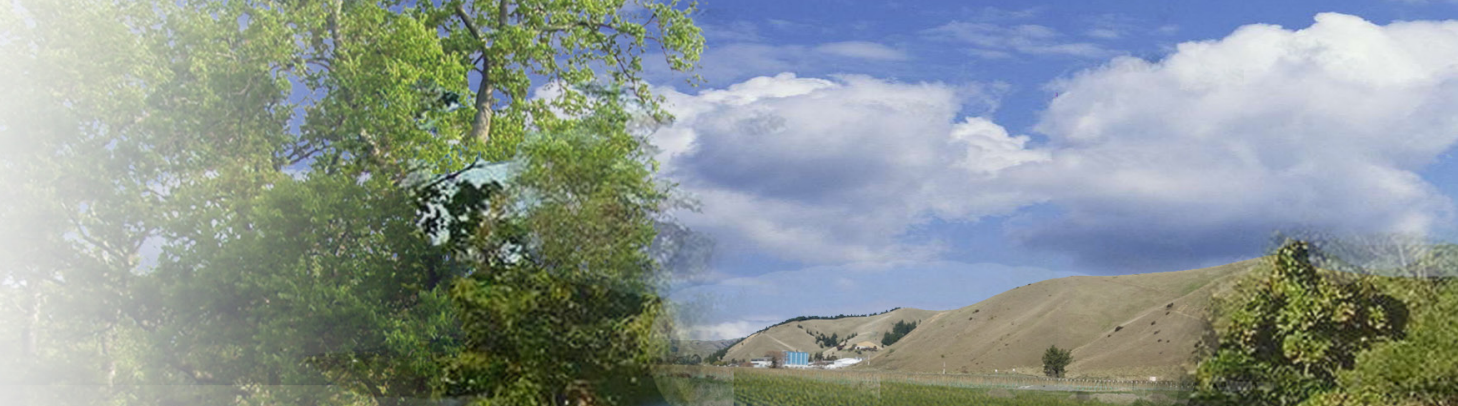

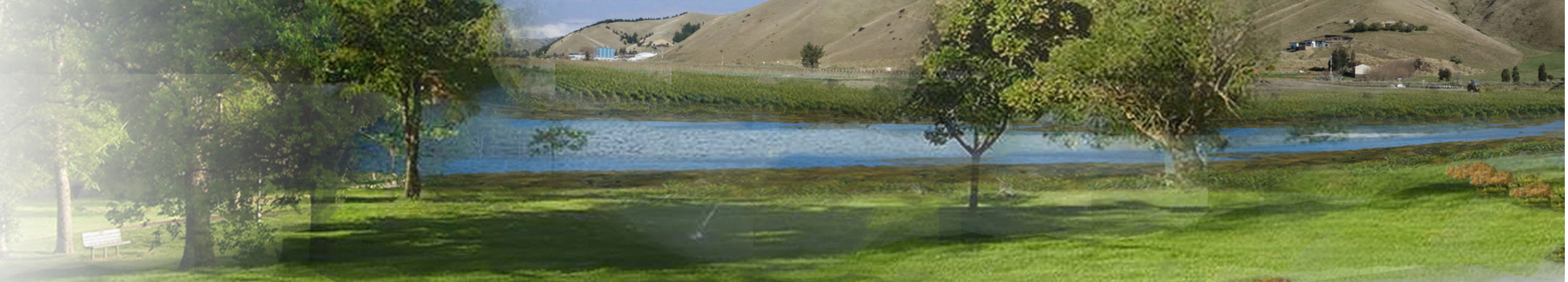

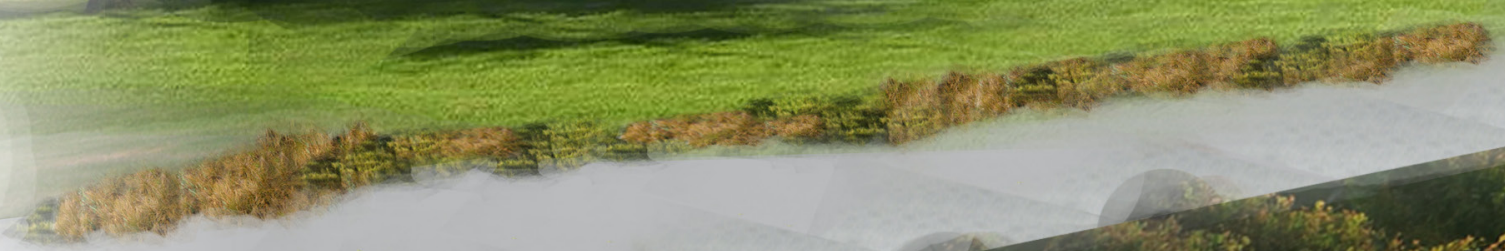

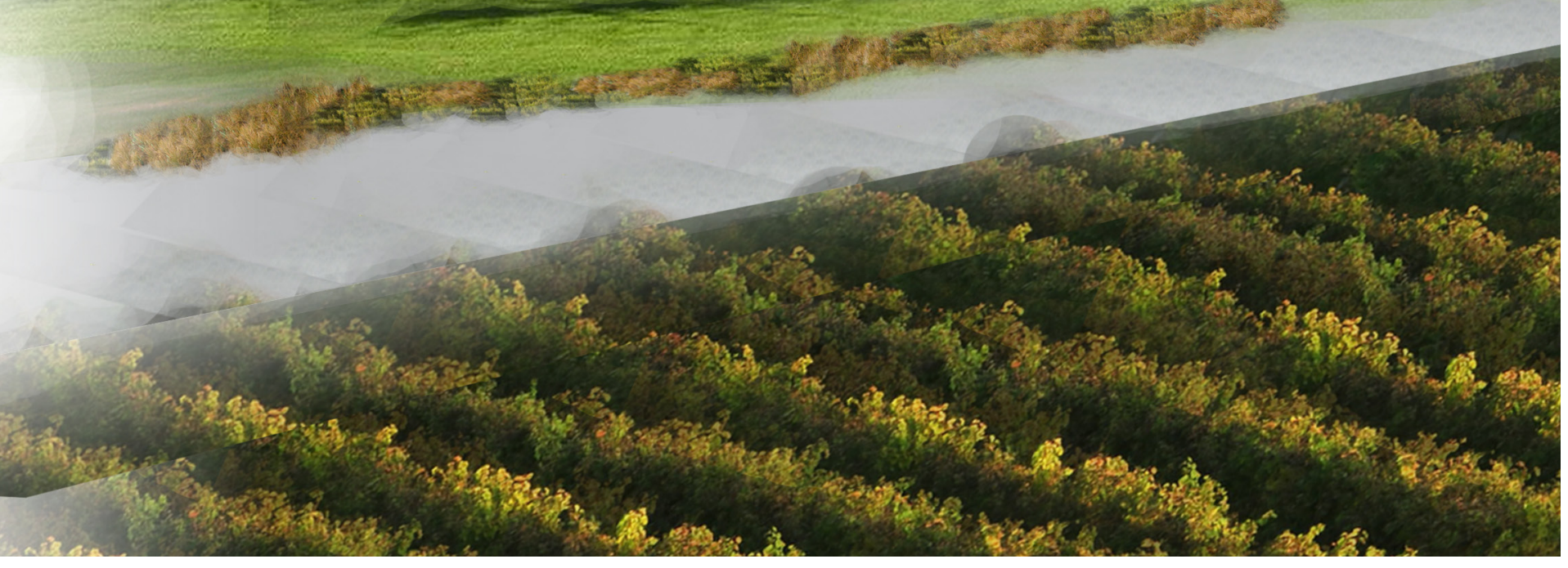

Fig 9.7 External People Experience 


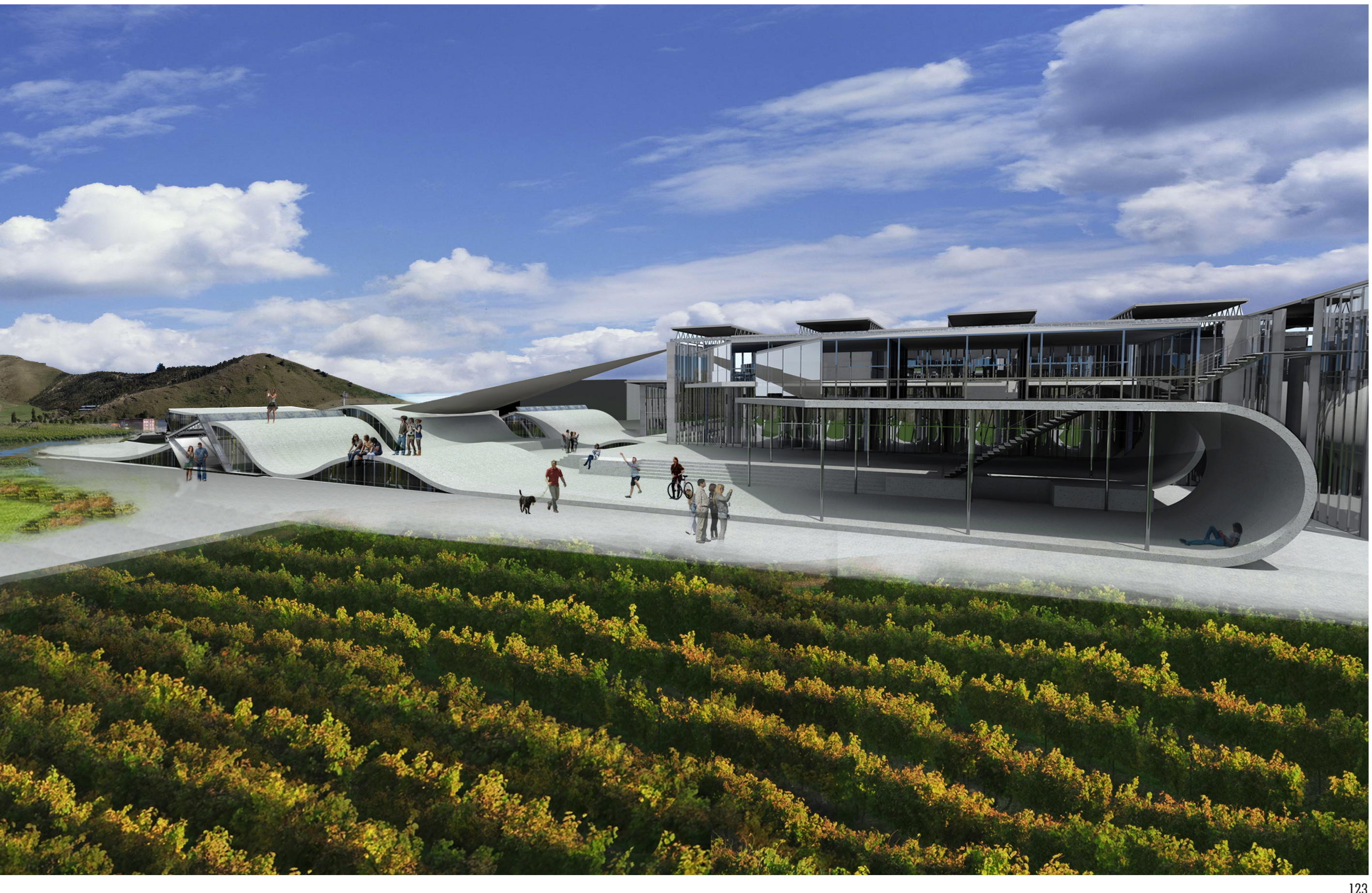




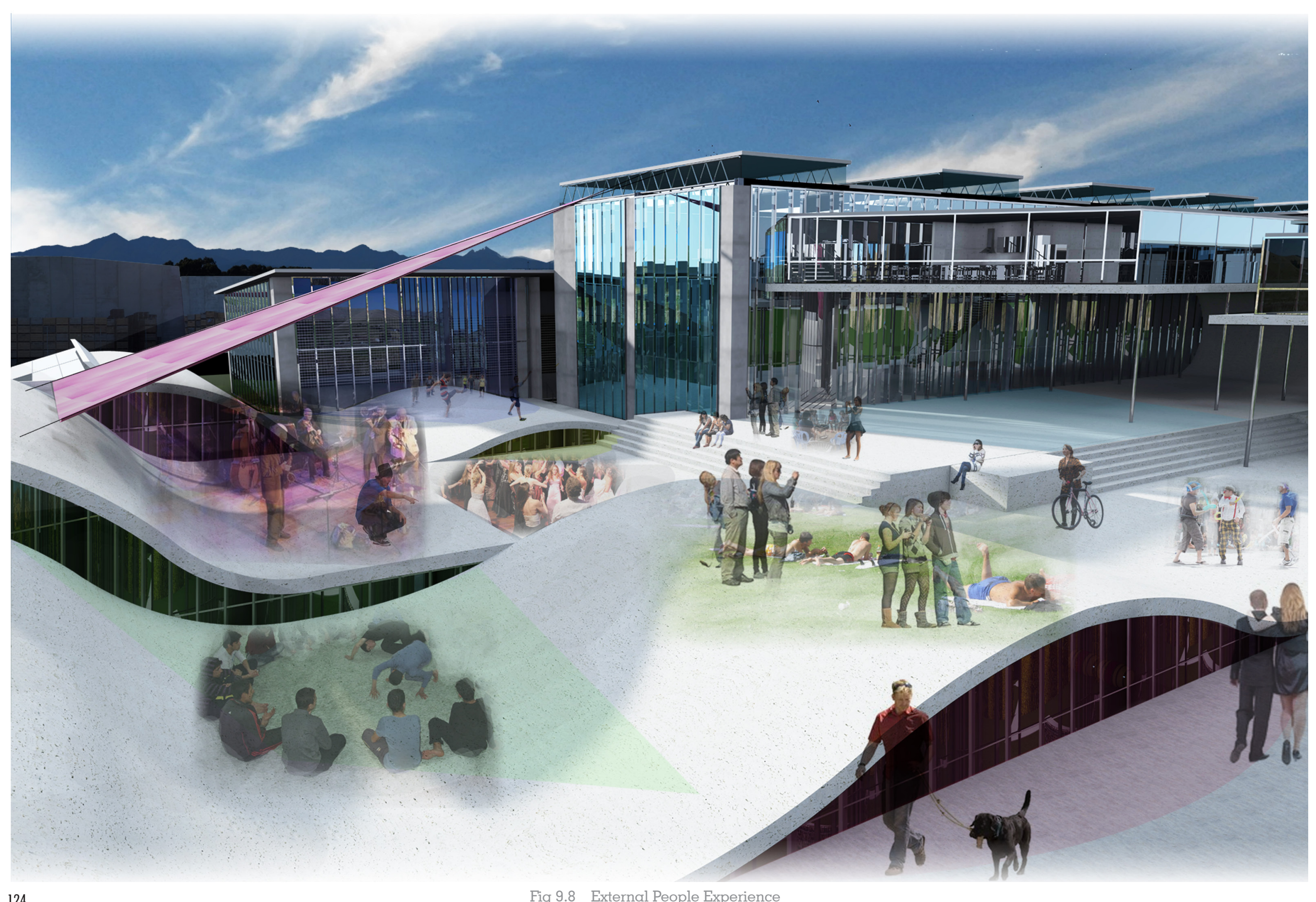




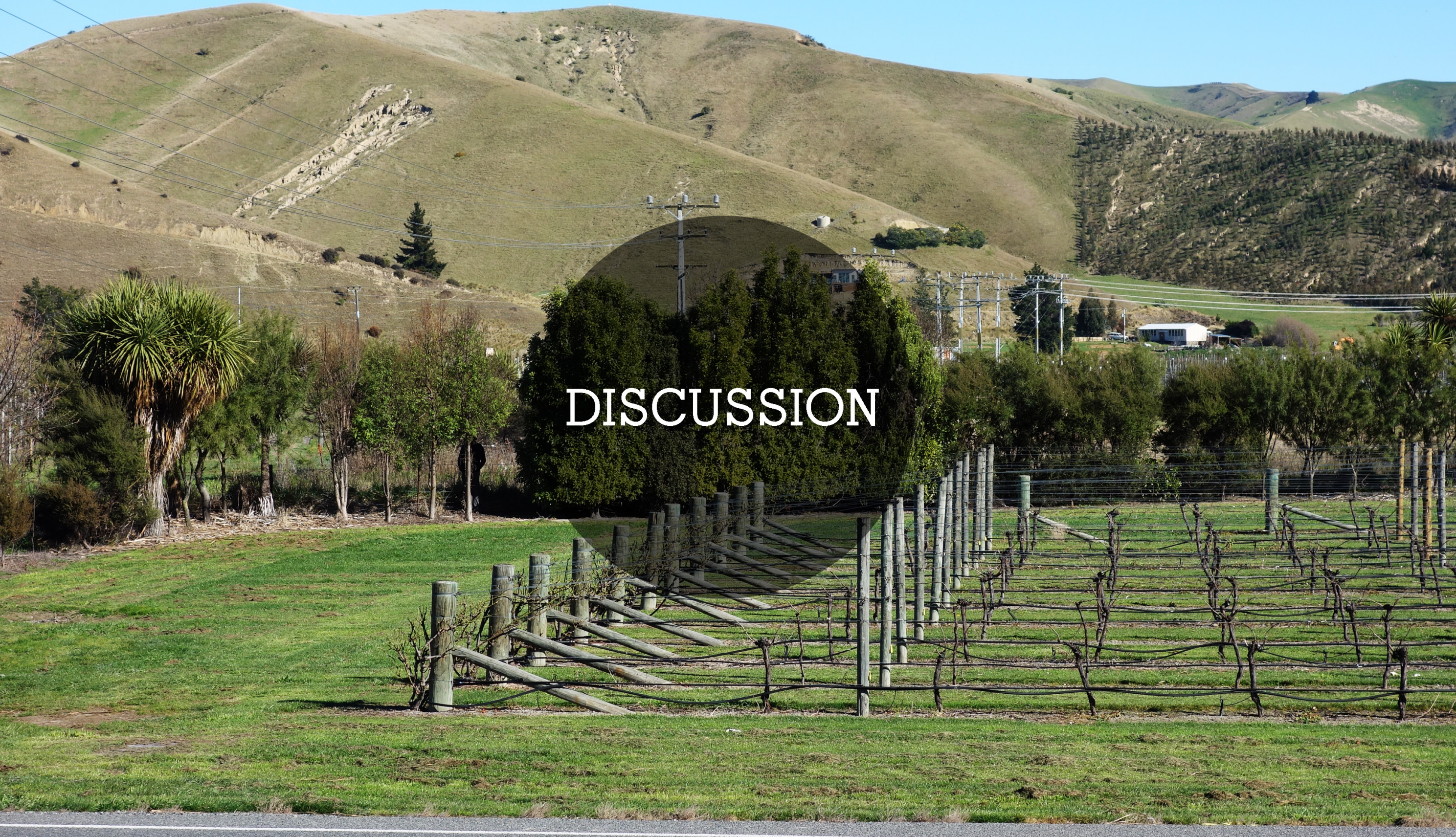




\subsection{DISCUSSION}

Discusses the design proposal referencing documented corporate architectures and the functional and experiential qualities of the building. 
The idea of corporate architecture has evolved over time and incorporated symbolism as well as theme parks designed to leave an experience rather than a visual image in the mind of the visitor. Originally corporate architecture was about translating corporate ideas through the functional and structural elements of a building until it became popular to create heavily emotive experiences through impressive contemporary formwork. An argument remains that although designing in this fashion can produce an impressive outcome that might incorporate company values. As a consequence, corporate building's programme may be moving away from the functionalist origins for a generally aesthetic experiential gain.

The investigation of a large corporate winery is fascinating because as an industrial building the product it creates is the main design driver. If the building produces wine that is of lesser quality due to the design, no matter the experiential quality of the building the building is ultimately a failure. The design investigation is largely designed around creating dual reasoning for architectural decisions. First and foremost any changes made to improve the experience must strive to aid or have minimal hindrance on the functionality of the building.

\section{$10.1 \quad$ PRODUCT EXPERIENCE BUILDING}

The Product Experience Building utilises a linear plan to ensure the process remains functional, the 
plan resembling a rectangular form. The facade itself is largely glass to the south ensuring quality lighting to workspaces and no direct sunlight to fermentation tanks. These building properties suggest that the design is similar to that of a decorated shed because of the way that the design is largely dictated by the function.

The addition the customer experience is based around providing insight into the making of the product without disrupting the process. In some cases, particularly on the exterior, requirements for the building to function efficiently contributed to visual interaction for the customer. An example of this is where the process requires vertical access for machinery from the fruit handling to the fermentation zones. What resulted was a retaining wall allowing access for driveways below the surface of the earth. This in turn revealed the full size of the tanks and provided opportunities to reference the terroir using caged gabion walls filled with local stones from the Wairau river. In this sense even the experiences are driven by the function meaning that the building leans towards a functionalist type building and exteriorly resembles qualities of a decorated shed.

Inside the building the experience is not driven by the process although it does not interrupt production Machinery can still pass easily below the access bridges to the tasting room and catwalks pass overhead easily. The glass walls of these bridges and tasting rooms allow visual interactions with all parts of the process as well as up close visuals of the stainless steel texture of the fermentation tanks. The caged gabion walls are also continued through the building into the tasting room and their breathability 
allows temperatures and smells to pass into the space further communicating the idea of product to the visitor. The inside experience has qualities of an inverted shed because of the way the inside facades are able to effectively break down the interface between public areas and process areas.

\subsection{PLANET EXPERIENCE BUILDING}

The Planet Experience also begins with a base linear design that ensures a continuous process and a rectangular form. The building also possesses a split roof similar to the product experience building to ensure quality lighting conditions to the catwalks.

The tower acts as a signage to the facility that houses the function, again demonstrating similar traits to the decorated shed. The tower is not completely ornamental because it contains fermentation tanks housed in a transparent, semi reflective facade however, the tower's primary function is the visitor experience not the process. The glass elevator within the tower transports guests to the tasting room rising amongst the huge fermentation tanks till finally arriving at the 360 degree viewing platform of the Marlborough region.

The production facility itself is purely functional and is not open to the public. What appears as an aesthetic reason for breaking the form actually assists the function. Water runoff is channelled into the 
wetland zones between buildings. The exterior facades are a mixture of green walls and algae panels both providing functional benefits through seasonal heat control at the same time communicating the value of planet to customers.

It is argued that the tower has decorated shed qualities because of the way the tower advertises the size and industry of Pernod Ricard while the production facility resembles the simple box. Others may argue that both the tower and the production facility have inverted shed qualities because of the way the insides interact with the public.

\subsection{PEOPLE EXPERIENCE BUILDING}

Analogue to the other two building complexes, the People Experience Facility also is arranged in a linear form, split roofing but with the inclusion of a barrel hall. The building has various functions that provide spaces for human/product interaction including a restaurant, a function room, a school of viticulture and performance stage.

The most notable aspect of the design is the concrete curving landform intended to architecturally reassemble the rolling hills of the surroundings. The public can move through this created landscape and get insights into the various stages of winemaking, thus the building fulfils programmatic and 
experiential functions. The folds of the form expose windows into the barrel hall effectively creating perforation to reduce the solidness of this interface providing visitors with an insight into the process. These folds also create viewpoints out across the river and the vineyard, a performance stage for wine and food festivals as well as areas for workers or visitors to relax, eat and drink. This formwork provides an interactive interface with many programmes within the building

\subsection{SUMMARY}

Together the buildings stand strong amongst the vineyard framing viewpoints and softening boundaries, each working in different ways translating specific company values. The designs collectively have taken design strategies from the Autostadt however have simplified the approach by only attributing values from one company to each building.

Although each building looks and communicates differently, the base planning design of the process remains very similar throughout to ensure the quality of the product is not affected. Other features such as the split roof, use of thermal massing and facade design depending on orientation are also translated through the different buildings to ensure a correct amount of lighting, airflow and climate is maintained in each part of the process. The communication of company values is driven by the user experience, which is incorporated into each of the design with the intent of achieving minimal impact 
on process. This is done through careful planning, manipulation of facade systems and incorporation of programmes.

What is obvious is that the designs are not functionalist nor experiential but lies between; a hybrid corporate architecture. Because of the hybrid nature of the designs, the buildings possesses attributes not only from decorated sheds that are in many ways functional, but also inverted sheds that attempt to make the functional an experience. 


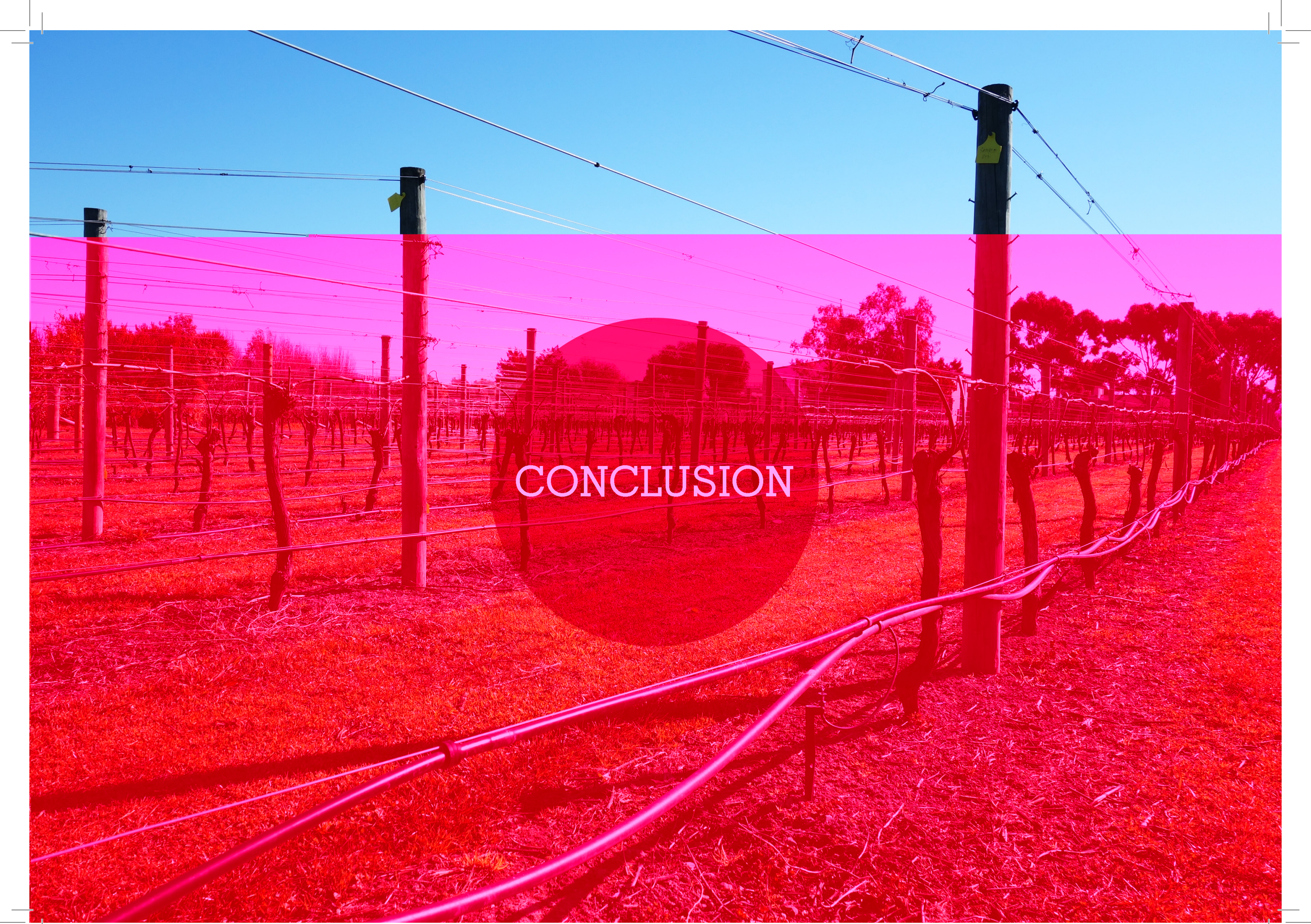




\subsection{CONCLUSION}

Reflects upon hybrid corporate architecture as a design driver for wineries. 
The success of corporate architecture is based mainly on a building's ability to communicate company values, as well as the public's response to the design. The thesis discusses how corporate architecture initially driven from the functionalist movement has shifted towards a more experience centred architecture driven by marketing. The car industry was used as an example to explore how architecture can help to express brand and corporate values. Here a shift from functional design drivers towards customer experience has been discussed.

Due to scale and economic viability, wineries require a modified approach that combines both function and experience within the same envelope. The thesis explores how a hybrid of these two design drivers can translate into a winery in Blenheim, New Zealand for Pernod Ricard's brand values, namely Planet, Product and People. Through design investigations these principles have been translated into a consumer winery experience.

Firstly the thesis investigates how Behrens was able to translate AEG's visual identity through design elements of the building. It became apparent that it is possible to directly relate parts of a corporate image to the building using functional architectural design elements. Secondly, another influence from previous corporate architectural literature is Venturi, Scott Brown and Izenour's definition of the 'decorated shed' and 'duck architecture'. The famous analysis of Las Vegas's strip provided a stark contrast between experiential and functional buildings. These relatively contrasting approaches of corporate architecture effectively revealed the middle ground between the two. Thirdly, Klingmann's 
'inverted shed' talks about breaking down the interface between public and process, functional and experience spaces, and this was essential for bringing together the two functional and experiential approaches together. This 'inverted shed' idea put a focus on the properties of facade systems and how one could be broken down to not only involve the public with internal processes of the building, but also speak the corporate values of the company.

Design developments realised that by dividing the building and attributing a value to each not only was more effective in communicating company values but also appropriated the scale of the winery to Marlborough's regional scale. These divided building could also be placed to soften boundaries and frame viewpoints which further contributed to the appreciation of the product. This also had functional benefits by organising grape varieties between facilities. Collectively each building incorporated a base plan driven by functional processes. This plan was modified slightly in each case to incorporate an experience of which the interfaces between public and process could be manipulated to communicate company values while benefitting the function.

Thus the thesis argues that a hybrid between functional and experience architecture provides a suitable framework for winery architecture. 

Reference List Allingham, P. (2009, June 6). Experimental Strategies for the Survival of Small Cities in Europe. European Planning Stud-

Autostadt. (2014). Explore the Autostadt. Retrieved from Autostadt Official Web Site: http://www.autostadt.de/en/explorethe-autostadt/car-towers/car-towers-ascent/

Bahamon, A., Canizares, A., \& Corcuera, A. (2009). Corporate Architecture: Building a brand. Barcelona: Parramon.

Banham, R. (1978). Theory and Design in the First Machine Age. London: The Architectural Press.

Behne, A. (1996). The Modern Functional Building. Santa Monica: Getty Center.

Boztepe, U. (2012). AEG \& Peter Behrens: Symbolism in the First Corporate Identity Design. Izmir.

Brodie, R. J., Benson-Rea, M., \& Lewis, N. (2008). Generic Branding of New Zealand Wine: From Global Allocator to Global Marketing. Auckland: University of Auckland.

Brunel, F. F. (2006). Design and the Big Five: Linking Visual Product Aesthetics to Product Personality. Boston: Boston University School of Management.

Buddensieg, T. (1979). Indsutrial Culture: Peter Behrens and the AEG 1907-1914. Berlin.

Carlsen, J. (2011). Assessing service quality at wineries and cellar doors through service mapping. International Journal of Wine, 23(3), 271-290.

Cosenza, G. (2006). The Olivetti Factory in Pozzuoli. Napoli: CLEAN.

DeBono, K. G., Leavitt, A., \& Backus, J. (2003). Product Packaging and Product Evaluation: An individual difference approach. Journal of Applied Social Psychology, 33(3), 513-521.

Feireiss, K., \& Kwinter, S. (2007). Dynamic Forces: Coop Himmelb(l)au; BMW Welt Munich . Munich: Prestel.

Fortini, F., Olivetti, A., \& Bigiaretti, L. (1958). Olivetti 1908 - 1958. (R. Musatti, L. Bigiaretti, \& G. Soavi, Eds.) Zurich: Tiefdruckanstalt Imago Ag.

Gago, P. (2014, July 23). Penfolds Winemaking Philosophy. (J. Sach, Interviewer)

Gendelman, I., \& Aiello, G. (2010). Faces of Places: Facades as Global Communication in Post Eastern Bloc Urban Renewal. In C. Thurlow, \& A. Jarworski, Semiotic Landscapes: Language, Image, Space (Advances in Sociolinguistics) (pp. 256-273). A\&C Black.

Gobe, M. (2001). Emotional Branding. New York: Allworth Press.

Guenther, M. (2012). Intersection: How Enterprise Design Bridges the Gap between Business, Technology and People. Newnres. 
Henderson, P. W., \& Cote, J. A. (1998). Guidelines for Selecting or Modifying Logos. Journal of Marketing, 68(4), 14-30.

Henderson, P. W., Giese, J. L., \& Cote, J. A. (2004). Impression Management using Typerface Design. Journal of Marketing, 68(4), 60-72.

Herbst, D. D., \& Maisch, B. (2009). The Potential of Corporate Architecture in Corporate Communication.

Holbrook, M. B., \& Hirschman, E. (1982). The Experiential Aspects of Communication: Consumer Fantasies, feelings and fun. Journal of Consumer Research, 9(2), 132-140.

Jordy, W. H. (2005). Robert Venturi and the Decorated Shed. In M. Bacon (Ed.), Symbolic Essence (pp. 261-275). New Haven, London: Yale University Press.

Klingmann, A. (2007). Brandscapes: Architecture in the Experience Economy. MIT Press.

Lasswell, H. D., \& Fox, M. B. (1979). The Signature of Power: Buildings, Communication and Policy. Transaction Publishers

MacKeith, P. (2005). The Dissolving Corporation: Contemporary Architecture and Corporate Identity in Finland. Helsinki: Talostleto Oy.

Melewar, T. C., \& Jenkins, E. (2002). Defining the Corporate Identity Construct. Corporate Reputation Review, 76-89.

Messedat, J. (2005). Corporate Architecture: Developments, Concepts, Strategies. Ludwigsburg: avedition GmbH.

Neumeier, M. (2003). The Brand Gap. Indianapolis: New Riders.

New Zealand Wine. (2011). Water and SWNZ. Retrieved from New Zealand Wine: http://www.nzwine.com/sustainability/ pillars-of-sustainability/water-4/water-and-swnz/

New Zealand Winegrowers. (2013). New Zealand Winegrowers Annual Report.

Oxford Dictionaries. (n.d.). dynamic. Retrieved from Oxford Dictionaries: http://www.oxforddictionaries.com/definition/english/dynamic

Paivio, A. U. (1986). Mental representations: a dual coding approach. Oxford: Oxford University Press.

Patton, P. (2000). Meet the Beetles Volkswagen's new theme park combines a unique brand of German showmanship with good old American razzmatazz. Metrpolis: New York, 20(3), 124-128.

Penfolds. (2014). About Our Vineyards. Retrieved from Penfolds Official Website: https://www.penfolds.com/heritage-andwinemaking/about-our-vineyards

Penfolds. (2014). Barossa Valley Cellar Door. Retrieved from Penfolds: https://www.penfolds.com/visit-penfolds/barossavalley-cellar-door

Penfolds. (2014). The Penfolds Vineyards. Retrieved December 9, 2014, from Penfolds Official Website: https://www.penfolds 
com/heritage-and-winemaking/the-penfolds-vineyards

Pevsner, N. (1986). Pioneers of Modern Design: From William Morris to Walter Gropius. London: Peregrine Books.

Pine, J., \& Gilmore, J. H. (1999). The Experience Economy . Boston: Harvard Business Press .

Raffelt, U., Littich, M., \& Meyer, A. (2011). Architectural Branding as Brand Communication: Does it contribute to employees' brand commitment? Marketing, 247-262.

Raffelt, U., Schmitt, B., \& Meyer, A. (2013). Marketing function and form: How functionalist and experiential architectures affect corporate brand personality. Intern Journal of Research in Marketing, 201-210.

Raffelt, U., Schmitt, B., \& Meyer, A. (2013). Marketing function and form: How functionalist and experiential architectures affect corporate brand personality. Intern Journal of Research in Marketing, 201-210.

Schittich, C. (2001). Building Skins: Concepts, Layers, Materials. (C. Schittich, Ed.) Detail.

Schmitt, B. H. (1999). Experiential Marketing, How to get customers to sense, feel, think, act and relate to your company and brands. New York: The Free Press.

Schumacher, T. L. (2010). "Facadism" Returns, or the Advent of the "Duck-orated Shed". Journal of Architectural Education, 128-137.

Schwanzer, K. (1975). Decisions on Form: The BMW Administration Complex in Munich. The Architect, 114.

Senior Lifestyle South Coast. (2011, January 1). Casella Family - Winemaking since 1820, pp. 65-66. Retrieved from https:// www.yellowtailwine.com/media/106668/010111\%20senior\%20lifestyle\%20south\%20coast,\%20casella\%20story.pdf

South Australia Government. (2014). Penfolds Barossa. Retrieved from The Official Site of The South Australian Tourism Commision: http://nz.southaustralia.com/info.aspx?id=9006140

Tans, K. L. (2011). SITE UNSCENE: Architecture as Event Interface. Cincinnatti: OhioLINK Electronic Theses and Dissertations Center.

Thalden, B. (1993). inlandreview: Learnig From Las Vegas: The Forgotten Symbolism of Achitectural Form. Inland Architect, 22-25.

Treasury Wine Estates. (2014, November 13). Penfolds: Australian Wine Producer of the Year. Retrieved from Treasury Wine Estates: http://www.tweglobal.com/2014/11/13/penfolds-named-australian-wine-producer-of-the-year/

Ursprung, P. (Ed.). (2005). Herzog \& de Meuron: Natural History. Lars Muller: Springer Science \& Business Media van Agtmael, A. (2007). Emerging Markets Century: How a New Breed of World-Class Companies is Overtaking the World. Simon and Schuster.

Venturi, R., Brown, D. S., \& Izenout, S. (1997). Bauwelt Foundation Series 53. Learning From Las Vegas: On the iconography and Archtiectural Symbolism of the Commercial Town, p. 24. 
Werner, F. R. (2009). Coop Himmelb(l)au BMW Welt, Munchen. Stuttgart/London: Edition Axel Menges.

Winepartners. (2009, September 10). New Wineries - Same old mistakes. Retrieved from winebiz: http://winepartners.wordpress.com/tag/brand-architecture/

Yellow Tail. (2014). Our Tale. Retrieved from Yellow Tail Official Website: http://www.discoveryellowtail.com/our-tale.php 


\section{Background Reading Balmer, J. M., \& Gray, E. R. (2003). Corporate brands: what are they? What of them? European Journal of Marketing, 972-}

Birkigt, K., Stadler, M. M., \& Funck, H. J. (2002). Corporate Identity: Principles, Uses, Case-Studies. Moderne Industrie. BMW Group. (2013, 07 09). 40 Years of BMW Headquarters and Museum. Retrieved 03 14, 2014, from BMW Group: PreddClub Global.

Bongers, R. (2010, December 10). Penfold's Winery - Nuriootpa - Barossa Valley. Retrieved from Panoramio: http://www. panoramio.com/photo/45306378

Bouskill, D., \& Corbell, D. (2013, July 24). A Barossa Valley Blend - DIY Wine Making. Retrieved from The Planet D: http:// theplanetd.com/two-grumpy-spaniards-and-a-barossa-valley-blend/

Brancott Estate. (n.d.). Wine Regions: Why Marlborough. Retrieved April 11, 2014, from http://www.brancottestate.com/ our-wines/wine-regions

Chicago Department of Planning and Development. (2007). Landmarks Designation Report: IBM Building. Chicago.

Cultivate Construction. (2006). Casella Wines. Retrieved from Cultivate Construction: http://cultivateconstruction.com. au/56/casella-wines/

Double Dutch Oven. (2011, June 3). Barossa Valley. Retrieved from Double Dutch Oven: https://doubledutchoven.wordpress.com/2011/06/

Dr. Dieter Herbst, B. M. (n.d.). The Potential of Corporate Architecture in Corporate Communication.

Entrepreneur Media. (2014). Branding. Retrieved from Entrepreneur: http://www.entrepreneur.com/encyclopedia/branding

Giovannini, J. (1997). Corporate Metamophosis. Architecture, 114-121.

Glancey, J. (2007, October 22). Brave new welt. The Guardian.

Grant, S. (2014, December 5). Penfolds Grange commands awe, even from those who work with it daily. The Australian. Retrieved from http://www.theaustralian.com.au/executive-living/luxury/penfolds-grange-commands-awe-even-fromthose-who-work-with-it-daily/story-e6frg8io-1227143372422?nk=66070d5512d8f65b30f8faebf96ef4d6

Ingenhoven Architects. (n.d.). Retrieved March 27, 2014, from http://www.ingenhovenarchitects.com/en/projects/giraproductionbuilding-radevormwald.html

Johnson, S. (2008, August). Designing the Contemporary Winery. a +u Architecture and Urbanism, pp. 82-87.

Jorda-Albinana, B., Ampuero-Canellas, O., Vila N, \& Rojas-Sola, J. I. (2009). Brand Identity Documentation: A crossnational examination of identity standards manuals. International MArketing Review, 172-97. 
Merriam Webster. (2014). deconstructivism. Retrieved March 19, 2014

Mies van der Rohe Society. (2012). One IBM Plaza. Retrieved 2014

New Zealand Wine. (2014). Marlborough. Retrieved April 11, 2014, from http://www.nzwine.com/wineries/marlborough/

Nistorescu, T., \& Barbu, C. (2008). Retail Store Design and Environment as Branding Support in the Services Marketing University of Craiova.

Pedersen, W., Smith, J., \& Hocking, D. (1997). IMB World Headquarters. In S. Dobney, The Master Architect Series II: KPF Selected and Current Works (pp. 84-89). Mulgrave: The Image Publishing Group Pty Ltd.

Percy, T. (2012). A Bloke for all Seasons: The Peter Yealands Story. Christchurch: Wily Publications Ltd.

Petromilli, M., Morrison, D., \& Million, M. (2002). Brand Architecture: building brand portfolio value. Strategy and Leadership, 30(5), 22-28.

Piggott , R. (2001). Building a brand for a country. Can commercial marketing practices achieve this in a government funded environment? University of Hull.

Schriefers, T. (1999). Built for demolition? In Comments on the History of the World's Fairs (p. 205). Hagen.

Tomlan, C. J. (2010). The Building Skin: Recladding as Renovatoin. mArch Thesis, Cincinatti.

Truong Anh Wines and Spirits Distribution. (2008). YELLOWTAIL - 10 पIIU NÊN BI $\square T$ T. Retrieved from Truong Anh: http://www. ruouvangngoai.com/index.php?page = productView2\&id $=409$

van Agtmael, A. (2007). Emerging Markets Century: How a New Breed of World-Class Companies is Overtaking the World. Simon and Schuster.

Web Urbanist. (2011, June 13). Deconstructivism: 7 Wonders of Postmodern Architeture. Retrieved March 19, 2014, from http:// weburbanist.com/2011/06/13/deconstructivism-7-architectural-wonders-of-the-world/

Wine Marlborough New Zealand. (2009). Marlborough's Wine History. Retrieved April 11, 2014, from http://www.wine-marlborough.co.nz/information-section/marlboroughs-wine-history/

Xu, F., \& Zhu, M. (2012, November 11). How to Manage Brand Architecture Strategy When Extending from B2B to B2C. Retrieved from Lab Brand: http://www.labbrand.com/knowledge/labrepo 
